\title{
ATRIBUTOS QUÍMICOS DA FRAÇÃO GROSSEIRA DE ALGUNS SOLOS DO SUDESTE BRASILEIRO
}

\author{
MARCIO ROBERTO SOARES
}

Engenheiro Agrônomo

Orientador: Prof. Dr. LUÍS REYNALDO FERRACCIÚ ALLEONI

Dissertação apresentada à Escola Superior de Agricultura "Luiz de Queiroz", Universidade de São Paulo, para a obtenção do título de Mestre em Agronomia, Área de Concentração: Solos e Nutrição de Plantas.

PIRACICABA

Estado de São Paulo - Brasil

Maio - 2001 


\section{ERRATA}

Pág. 40 (linhas 27 e 28) - onde se lê "a hematita pode se hidratar e formar goetita", leia-se " a hematita pode sofrer redução e liberar $\mathrm{Fe}^{+2}$ para a solução, o qual pode se reprecipitar na forma de goetita".

Pág. 41 (linha 3) - onde se lê "acúmulo de água constante", leia-se "lençol freático flutuante".

Difratogramas pág. 44 a 49 - equipamento Philips com tubo de cobre.

Difratogramas pág. 51 a 62,70 e 71 - equipamento Siemens com tubo de cobalto.

Pág. 68 (linha 8) - onde se lê "A proporção de terra fina", leia-se "A proporção de cascalho".

Pág. 69 (linha 2) - onde se lê "superficiais", leia-se "subsuperficiais".

Pág. 74 (linha 22) - onde se lê " $60 \%$ ", leia-se $40 \%$.

Nas tabelas 11 e 12 (pág. 78 e 86, respectivamente) - onde se lê "CTC mineral", leia-se "CTC dos silicatos".

Na tabela 11 (pág. 78) - onde se lê "profundidade em m", leia-se "profundidade em cm". 
Dados Internacionais de Catalogação na Publicação (CIP) DIVISĀO DE BIBLIOTECA E DOCUMENTAÇĀO - Campus "Luiz de Queiroz"/USP

Soares, Marcio Roberto

Atributos quimicos da fraçăo grosseira de alguns solos do Sudeste brasileiro / Marcio Roberto Soares. - - Piracicaba, 2001.

$105 \mathrm{p}$.

Dissertação (mestrado) - - Escola Superior de Agricultura Luiz de Queiroz, 2001. Bibliografia.

1. Granulometria do solo 2. Minerologia do solo 3. Propriedade quimica 4. Quimica do solo I. Título

CDD 631.411

Pemitida a copha tot l ou parcial deste locumento, dexde que citala a fonte- O autor: 
Aos meus queridos pais, Demerval e Isabel,

pelo inestimável esforço

que sempre fizeram em meu proveito

e à minha querida irmã, Kátia,

\section{OFEREÇO}

À Thaíssa,

pelo carinho e incentivo. 


\section{AGRADECIMENTOS}

Ao Prof. Dr. Luís Reynaldo Ferracciú Alleoni pela orientação, amizade e apoio durante a realização deste trabalho.

Ao Prof. Dr. José Carlos Casagrande (Universidade Federal de São Carlos - CCA- UFSCar / Araras) pela sua grande importância na definição da minha carreira.

À Coordenação do Programa de Pós-graduação em Solos e Nutrição de Plantas pela oportunidade e aos membros docentes do curso, em especial aos Profs. Drs. Pablo Vidal-Torrado e Célia Regina Montes pelas importantes sugestões e auxílio para o enriquecimento da dissertação.

Aos funcionários do Departamento de Solos e Nutrição de Plantas da ESALQ/USP, Dorival Grisotto, Luciano Ferraz, Wladimir Rosignolo, Maria Elisabete Guimarães, Luís Silva, Nivanda de Moura, Lúcia Forti, Gertrudes Fornazier, pela amizade e contribuição na condução das análises laboratoriais.

Aos amigos Tiago Osório Ferreira, Rogério Campos, Ricardo Romero e Michel Cambri pelo convívio e companheirismo. Menção especial ao amigo Edson Fernando Madruga pelo exemplo de pessoa e de profissionalismo.

À Coordenação de Aperfeiçoamento de Pessoal de Nível Superior (CAPES) pela concessão da bolsa de estudos.

A todas as pessoas que, de maneira direta ou indireta, contribuíram para a construção deste trabalho.

Por tudo que alcancei até hoje, a DEUS eu agradeço. 


\section{SUMÁRIO}

Página

RESUMO vi

SUMMARY viii

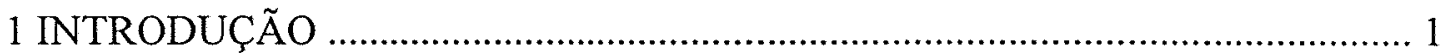

2 REVISÃO DE LITERATURA ................................................................. 3

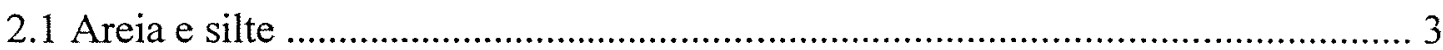

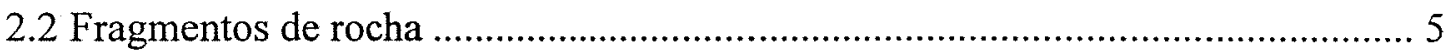

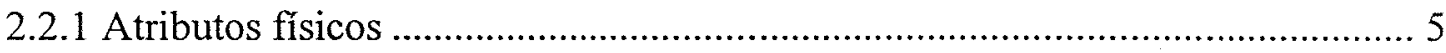

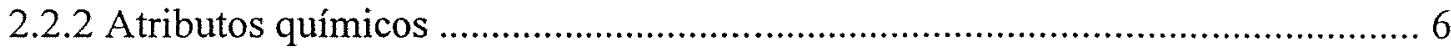

2.3 Fenômenos de superfície ........................................................................ 7

2.3.1 Capacidade de troca catiônica ....................................................................... 7

2.3.2 Capacidade de troca aniônica ................................................................ 8

2.3.3 Desenvolvimento de cargas ............................................................. 9

2.3.4 Influência dos óxidos na determinação da CTC e CTA ................................ 10

2.3.5 Efeitos da matéria orgânica sobre a troca iônica ........................................ 11

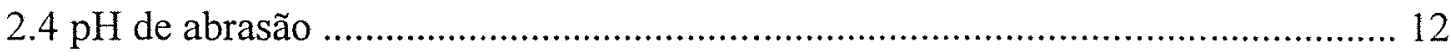

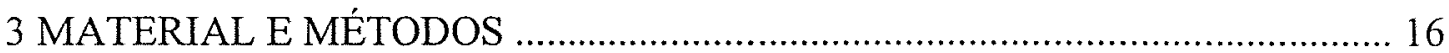

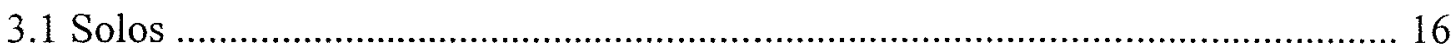

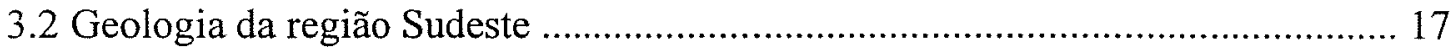

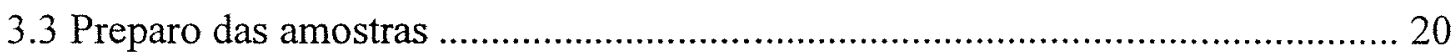

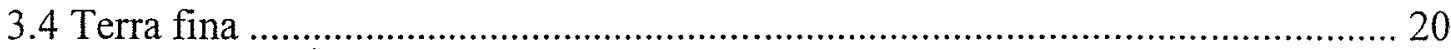

3.4.1 Separação das frações granulométricas ..................................................... 20

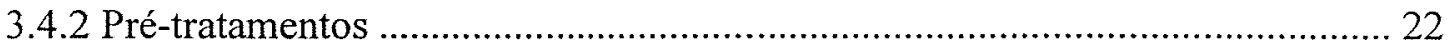

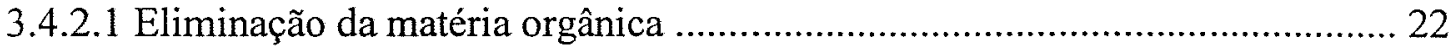

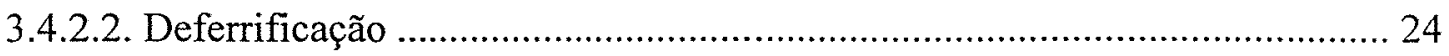

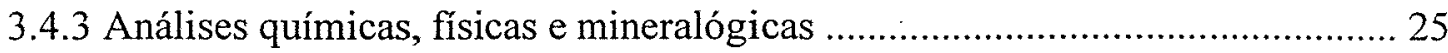

3.4.3.1 Análises químicas de rotina e complementares ....................................... 25

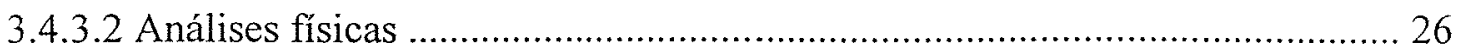

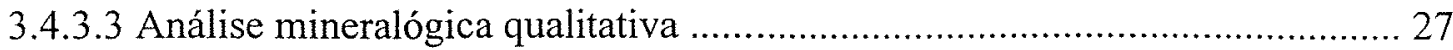




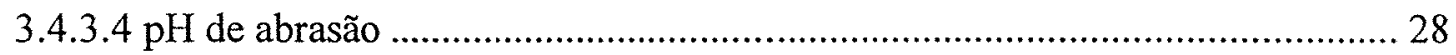

3.4.4 Determinação da CTC e CTA em $\mathrm{BaCl}_{2}$..................................................... 28

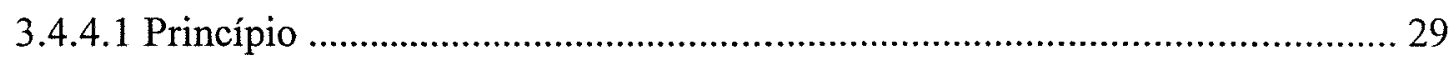

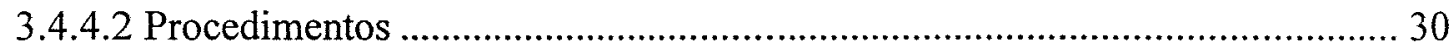

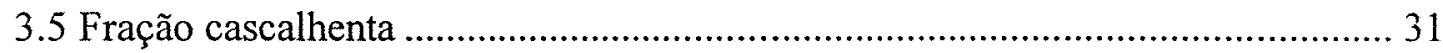

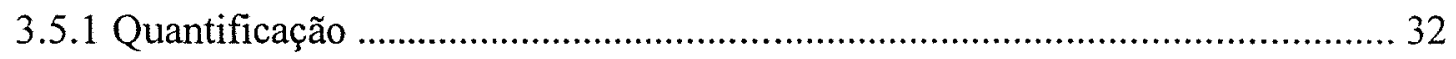

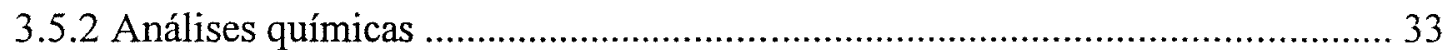

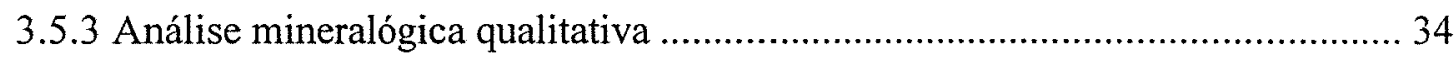

3.6 Análise estatística ........................................................................................ 34

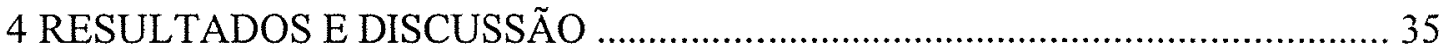

4.1 Análises químicas ............................................................................................ 35

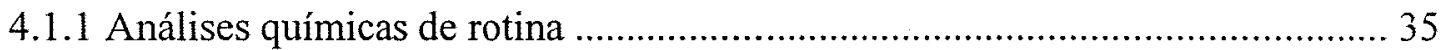

4.1.2 Análises químicas complementares ........................................................... 38

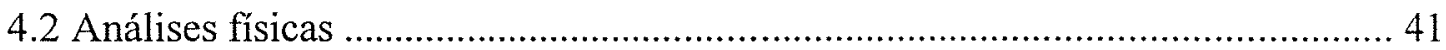

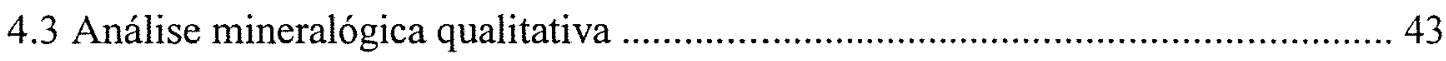

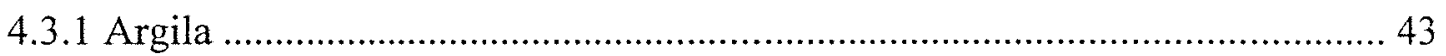

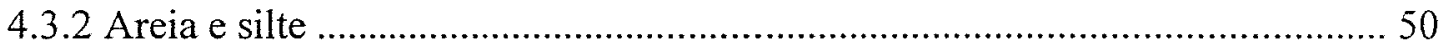

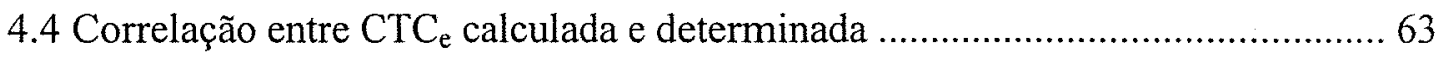

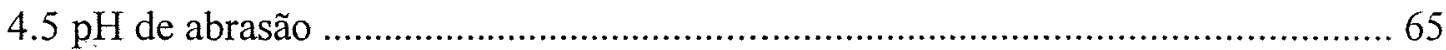

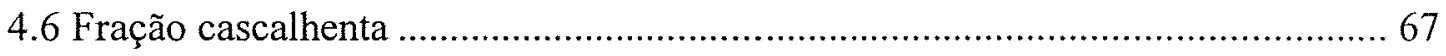

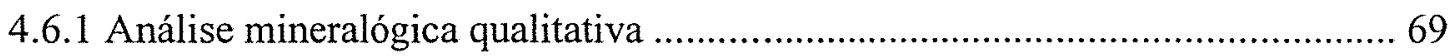

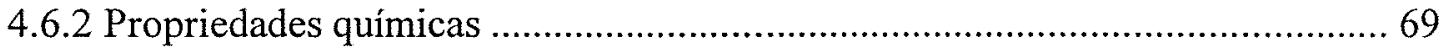

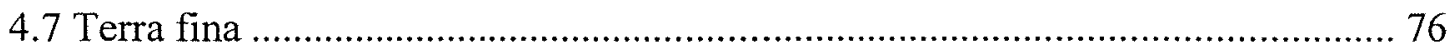

4.7.1 Correlações entre $\mathrm{CTC}_{\mathrm{e}} \mathrm{e}$ alguns atributos dos solos ...................................... 76

4.7.2 Correlações entre $\mathrm{CTA}_{\mathrm{e}}$ e alguns atributos dos solos ..................................... 82

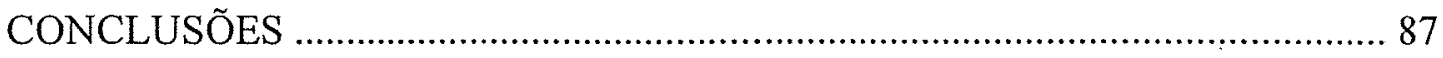

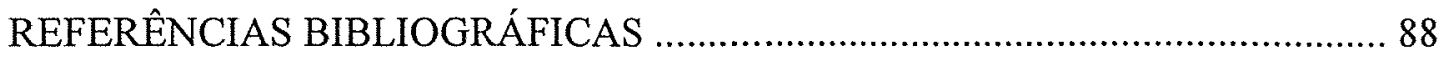

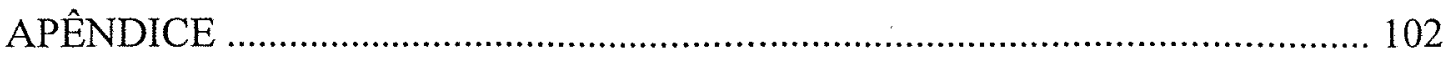




\title{
ATRIBUTOS QUÍMICOS DA FRAÇÃO GROSSEIRA DE ALGUNS SOLOS DO SUDESTE BRASILEIRO
}

\author{
Autor: MARCIO ROBERTO SOARES \\ Orientador: Prof. Dr. LUÍS REYNALDO FERRACCIÚ ALLEONI
}

\section{RESUMO}

As características e o comportamento dos solos sempre estiveram relacionados a terra fina, notadamente à fração argila. Poucos estudos têm se dedicado à importância e significado das frações grosseiras, tais como silte, areias e fragmentos de rocha, que influenciam quase exclusivamente as propriedades físicas do solo, sendo consideradas inertes sob o ponto de vista químico. Este trabalho teve por objetivo estudar a contribuição destas frações para o comportamento químico de solos representativos da região Sudeste do Brasil, considerando diferenças litológicas e texturais.

Avaliou-se, por meio de correlações lineares simples e regressões múltiplas, o efeito dos atributos químicos do solo para fins de fertilidade, dos teores de óxidos de ferro e alumínio, e dos teores de argila, silte e cinco subfrações de areia (muito fina, fina, média, grossa e muito grossa) na capacidade de troca catiônica $\left(\mathrm{CTC}_{\mathrm{e}}\right)$ e aniônica $\left(\mathrm{CTA}_{\mathrm{e}}\right)$ efetivas, determinadas em solução tamponada de $\mathrm{BaCl}_{2}$.

$\mathrm{A} \mathrm{CTC}_{\mathrm{e}}$ apresentou alta correlação positiva com os atributos químicos das frações mais grossas da terra fina e com a matéria orgânica. Na análise conjunta, a $\mathrm{CTC}_{\mathrm{e}}$ da areia muito fina e o teor de matéria orgânica explicaram $85 \%$ da variação da $\mathrm{CTC}_{\mathrm{e}}$ do solo. A $\mathrm{CTA}_{\mathrm{e}}$ correlacionou-se significativamente com o teor de alumínio, resultante do ataque com ácido sulfúrico, e com o teor de argila. 
$\mathrm{Na}$ análise conjunta, $56 \%$ da variação da $\mathrm{CTA}_{\mathrm{e}}$ nos solos foi explicada pelos teores de $\mathrm{Al}_{2} \mathrm{O}_{3}$, matéria orgânica e areia grossa, e pela saturação por alumínio.

Atributos químicos de superfície também foram interpretados como função da mineralogia e estádio de intemperização dos solos. $\mathrm{O}$ pH de abrasão foi empregado como índice na determinação da fertilidade potencial do solo, e se correlacionou negativamente com o teor de areia média+fina.

A reatividade dos fragmentos de rocha depende da litologia e, juntamente com as frações mais grossas da terra fina, podem desempenhar importantes funções nos solos, não sendo, portanto, quimicamente inertes. 


\title{
COARSE FRACTION CHEMICAL ATRIBUTTES OF SOME SOILS FROM BRAZILIAN SOUTHEAST
}

\author{
Author: MARCIO ROBERTO SOARES \\ Adviser: Prof. Dr. LUÍS REYNALDO FERRACCIÚ ALLEONI
}

\section{SUMMARY}

The properties and the behavior of the soils have always been related to fine earth activity, especially clays. Few studies have been dedicated to the coarse fraction, such as silt, sand and rock fragments, whose presence is usually correlated with physical properties being, therefore, considered chemically inert. The objectives of this study were to evaluate the contribution of these fractions on chemical behavior of representative Brazilian Southeast soils, considering lithologic and textural differences.

The influence of chemical attributes presented in routine soil fertility analysis, the $\mathrm{Fe}$ and $\mathrm{Al}$ extractable oxides contents, and clay, silt and five sand sub-fractions (fine, very fine, medium, coarse and very coarse) contents were correlated to the effective cation exchange capacity (ECEC) and effective anion exchange capacity (EAEC), obtained by unbuffered $\mathrm{BaCl}_{2}$ solution, by means of simple correlation and multiple regression analysis.

ECEC was highly correlated with chemical attributes of coarser fractions of the fine earth and with organic matter contents. Eighty five percent of the variation in soil ECEC could be related to the organic matter and very fine sand contents. On the other hand, the effective anion exchange capacity of soils significantly correlated with aluminum oxides, obtained after sulfuric acid attack, and with clay content. However, fifty six percent of EAEC variation was 
explained by the significant correlation between aluminum oxides, organic matter, coarse sand and aluminum saturation. Surface physical-chemical attributes were also interpreted as a function of soils mineralogy and weathering. Abrasion $\mathrm{pH}$ was used as an indicator of soils potential fertility showing, however, a negative correlation with fine+medium sand contents.

The relation between fine earth and rock fragments properties suggested that their reactivity depends on lithology. Consequently, those fraction may have a significant importance in soils, therefore, they should not be considered chemically inert. 


\section{INTRODUÇÃO}

As frações granulométricas do solo diferem substancialmente na forma cristalográfica e na composição química. Por isso, a elas são atribuídos distintos significados e graus de importância sob o ponto de vista agrícola.

A maioria dos estudos referentes ao comportamento químico do solo está centrada na porção correspondente à terra fina (frações com diâmetro inferior a 2 $\mathrm{mm}$ ), notadamente nas argilas que, juntamente com a matéria orgânica, compõem a fração mais ativa do complexo coloidal do solo, ao qual são atribuídos importantes atributos químicos e físico-químicos de importância para a sua fertilidade.

Poucos estudos têm avaliado a importância das frações grosseiras do sọlo, como as areias, os siltes e fragmentos de rocha. Sua presença se relaciona quase que exclusivamente com a influência que exercem nas propriedades físicas do solo, sendo consideradas, sobretudo as de maior tamanho, quimicamente inertes. No entanto, o interesse por estas frações se assenta na influência que possam ter nas propriedades químicas, como a CTC, a CTA e a capacidade de adsorção de elementos, íons e compostos.

A região tropical abriga vários solos, com diferentes texturas e graus de fertilidade. O clima, caracterizado pela alta temperatura e umidade, exerce influência marcante nas composições química e mineralógica das frações granulométricas. O intenso intemperismo acarreta o predomínio de caulinita e óxidos de $\mathrm{Fe}$ e $\mathrm{Al}$, considerados colóides de comportamento anfótero, devido à 
reversibilidade de cargas da sua superfície sob diferentes condições de $\mathrm{pH}$, sendo que a CTC passa a ser dependente, quase que exclusivamente, da matéria orgânica. Considerando que os níveis naturais de matéria orgânica são difíceis de serem mantidos em sistemas intensivos de produção, torna-se importante o estudo da contribuição da fração grosseira para as propriedades químicas destes solos.

Neste contexto, partindo-se da hipótese que as frações grosseiras do solo não são quimicamente inertes e que podem desempenhar funções importantes não só de ordem física, mas também química, os objetivos deste trabalho são quantificar a influência das frações areia e do silte nas propriedades químicas do solo e avaliar as características químicas dos fragmentos de rocha e compará-los com as da terra fina. 


\section{REVISÃO DE LITERATURA}

Os constituintes sólidos do solo consistem de uma variedade de compostos orgânicos e inorgânicos. O complexo coloidal, do qual fazem parte os minerais de argila, a matéria orgânica humificada e os óxidos e hidróxidos, é considerado a sede dos fenômenos físico-químicos de superfície. Muitos dos materiais grosseiros, classe em que se incluem a areia, o silte, fragmentos de rocha e material orgânico pouco decomposto, são, via de regra, quimicamente inertes.

\subsection{Areia e silte}

A granulometria pode influir na produtividade das culturas de diversas maneiras. Solos muito arenosos apresentam, em geral, baixos teores de matéria orgânica, baixa capacidade de retenção de nutrientes e, principalmente, baixa capacidade de retenção de água (Raij, 1991). O silte pode concorrer para a compactação e incrustração da superficie, embora assegure, juntamente com a argila, a movimentação lenta da fase líquida e gasosa do solo (Brady, 1989).

Por possuírem dimensões acima de $0,002 \mathrm{~mm}$, o silte e as subfrações de areia não exibem propriedades coloidais e possuem baixa superfície específica. Participam de poucas reações no solo ao apresentarem alguma capacidade de adsorção, mas somente desempenharão alguma atividade química ao se 
intemperizarem para formar argila (Olier, 1969; Rai, 1989; Churchman, 2000; Olson et al., 2000).

A distribuição da fração areia e seu conteúdo dentro do perfil pode fornecer informações acerca do grau de evolução (Dorronsoro, 1988; Dorronsoro et al., 1988), da fertilidade potencial (Ferrari \& Magaldi, 1983) e, dependendo da mineralogia, da fertilidade atual (Taboada et al., 1990). Tedrow (1965) e Thompson et al. (1989) encontraram valores de CTC variando de 20 a $220 \mathrm{mmo}_{\mathrm{c}}$ $\mathrm{kg}^{-1}$ em silte e frações de areia.

A reserva mineral de Ultissols e Inceptssols de diferentes idades e litologias, estimadas em sua fração areia fina, pode variar de 950 a $1700 \mathrm{mmol}_{\mathrm{c}}$ $\mathrm{kg}^{-1}$ (Ferrari \& Magaldi, 1983). Turpault et al. (1996) demonstraram a efetiva contribuição das areias e limos na fertilidade atual de solos ácidos florestados da França, ao encontrarem valores de CTC variando de 3 a $52 \mathrm{mmol}_{\mathrm{c}} \mathrm{kg}^{-1}$ para a areia grossa, 10 a 110 para a areia fina e 17 a 390 para o silte. Estes resultados indicam participação de 35 a $80 \%$ na CTC efetiva da fração inorgânica da terra fina, atribuída à mineralogia das areias e limos, abundantes em filossilicatos 2:1.

Minerais de quartzo e feldspato, principais componentes da fração areia e silte (Brady, 1989), podem desempenhar uma importante função química no solo Tedrow (1965). No entanto, partículas de dimensão física correspondente às frações areia e silte podem ser compostas de agregados de argila, como no caso da glauconita, que apresenta argila micácea na sua constituição. Tedrow (1965) encontrou valores de CTC variando entre 190 e $310 \mathrm{mmol}_{\mathrm{c}} \mathrm{kg}^{-1}$ para a glauconita (considerada no estudo como fração areia) atribuídos à contribuição da superfície reativa das argilas da sua composição. Turpault et al. (1996) enfatizaram que, em solos ácidos, nem sempre a CTC está concentrada na matéria orgânica e fração argila, pois as subfrações de areia podem contribuir substancialmente para este atributo. 


\subsection{Fragmentos de rocha}

Miller \& Guthrie (1984) definiram material grosseiro ou fragmentos de rocha como partículas de diâmetro igual ou superior a $2 \mathrm{~mm}$, que constituem o esqueleto do solo.

Solos com fragmentos de rocha representam importante proporção dos recursos que podem ser utilizados para a produção de alimentos e fibras e, portanto, o entendimento sobre o seu comportamento é necessário para estabelecer seu potencial de uso (Miller \& Guthrie, 1984; Ingelmo et al., 1994). Estes solos aparecem tanto em zonas erosivas como em zonas de acumulação (sedimentação) e, em algumas ocasiões, correspondem a solos em que a maior parte da terra fina foi perdida por erosão hídrica ou eólica, no intento de superar sua capacidade produtiva submetendo-os a cultivos intensos (Poesen \& Lavee, 1994). Sua ocorrência é generalizada na região dos trópicos (Babalola \& Lal, 1977), embora, na última década, o aumento do interesse pelo estudo de solos com fragmentos de rocha esteja centrado na área mediterrânea, onde ocupam cerca de $60 \%$ da superfície (Poesen \& Lavee, 1994).

\subsubsection{Atributos físicos}

A maioria dos estudos aborda o impacto destas frações nos atributos físicos do solo, no fluxo e retenção de água, estruturação, erosão e compactação (Coile, 1953; Hanson \& Blevins, 1979; Childs \& Flint, 1994; Poesen \& Lavee, 1994; Ingelmo et al., 1994). A literatura encerra trabalhos conflitantes a respeito do efeito dos fragmentos de rocha nas propriedades do solo. Em solos argilosos, o material grosseiro pode facilitar a movimentação da fase líquida e gasosa, pelo aumento expressivo da macroporosidade. Seu efeito deletério está na baixa retenção de água, em função da redução da microporosidade. 
Ugolini et al. (1996) citaram o aumento da porosidade dos fragmentos em função do intemperismo, pela dissolução dos minerais primários. Em conseqüência do aumento no fluxo de água pela maior porosidade, a alteração dos fragmentos é aumentada, criando mais poros. O grau de intemperização, aliado a natureza e tamanho do fragmento, condiciona sua apreciável capacidade de retenção de água.

\subsubsection{Atributos químicos}

Poucos trabalhos destinaram-se ao estudo dos atributos químicos dos fragmentos de rocha (Tedrow, 1965; Rivard \& De Kimpe, 1980; Turpault, 1996), devido a estas frações, pelo tamanho, serem consideradas inertes. Porém, propriedades desejáveis sob o ponto de vista agrícola, referentes à alta porosidade, retenção de água, capacidade de troca de íons e grande reserva de nutrientes têm sido atribuídas à fração grosseira (Ugolini et al. 1996). Esta fração apresenta propriedades similares às da terra fina, como a CTC e conteúdo de $\mathrm{C} e$ N (Ugolini et al., 1996; Corti et al., 1997), que dependem do grau de alteração em que se encontra (Corti et al., 1998). Ugolini et al. (1996) chegaram a atribuir $39 \%$ da CTC total do solo aos fragmentos de rocha e $61 \%$ a terra fina, em solos florestados. Deutschmann (1994), citado por Ugolini et al. (1996), em suas recentes determinações em fragmentos de arenito, encontrou valores de CTC variando de 1 a $95 \mathrm{mmol}_{\mathrm{c}} \mathrm{kg}^{-1}$. Rivard \& De Kimpe (1980) registraram, em solos desenvolvidos sobre o mesmo material de origem, contribuição de $69 \%$ na CTC mineral total do solo por parte dos fragmentos de rocha. 


\subsection{Fenômenos de superfície}

\subsubsection{Capacidade de troca catiônica}

A capacidade de troca catiônica (CTC) é um atributo de grande interesse prático, principalmente em estudos de fertilidade, pois o potencial de produtividade de um solo é proporcional à magnitude deste atributo. "É a segunda reação mais importante na natureza, suplantada em fundamental importância somente pelo processo fotossintético das plantas verdes" (Marshall, 1967, p.57). A CTC é definida por Raij (1969) como uma característica físico-química que indica a quantidade de íons positivos que um solo é capaz de reter e permutar, em determinadas condições, por quantidades estequiometricamente equivalentes de íons de mesmo sinal.

Sposito (2000) apresentou definição mais complexa dos fenômenos que envolvem mecanismos físico-químicos no solo: a capacidade de troca iônica de um solo é o número de mols de carga de íon adsorvido que pode ser dessorvido por unidade de massa do solo, sob dadas condições de temperatura, pressão, composição da solução do solo e relação entre a massa de solo e solução. Referese à adsorção máxima de íons prontamente disponíveis que são adsorvidos na superfície das partículas do solo somente por atrações eletrostáticas e íons presentes na camada difusa.

Sumner \& Miller (1996), citados por Sposito (2000), relataram a importância do uso de cátions índice para a determinação da CTC. Em solos nos quais os cátions prontamente trocáveis são tipicamente monovalentes ou bivalentes, o íon índice pode ser $\mathrm{Ca}^{+2}$, enquanto que $\mathrm{Ba}^{+2}$ ou $\mathrm{K}^{+}$são os cátions índice empregados para solos em que a predominância é de cátions trocáveis trivalentes. Freqüentemente, $\mathrm{NH}_{4}{ }^{+}$é usado como cátion índice (Rhoades, 1982). Porém, este cátion forma complexos de superficie do tipo esfera interna (adsorção 
específica, covalente) com minerais de argila de grade 2:1, e pode até mesmo desalojar cátions de minerais primários facilmente intemperizáveis, superestimando a capacidade de troca de cátions (Rasmussen et al., 1991). A CTC efetiva calculada, resultante da soma de bases mais a acidez potencial extraída em acetato de cálcio a $\mathrm{pH} 7,0$, é amplamente empregada em análises de rotina, constituindo um método indireto de determinação da CTC. A determinação direta da CTC feita no Instituto Agronômico de Campinas emprega o método descrito por Raij (1966), pelo uso do acetato de cálcio a $\mathrm{pH} 7,0$, com pequenas modificações. Outra opção é a determinação, em meio tamponado, com acetato de amônio. Este método é de uso restrito para o deslocamento de $\mathrm{K}^{+}$, sendo evitado por promover aumento de cargas negativas, pela elevação do $\mathrm{pH}$, e por reagir especificamente com os colóides do solo (Gillman \& Sumpter, 1986). Dados na literatura evidenciam o cloreto de bário como o melhor deslocador de cátions e, por isso, é empregado na determinação direta da CTC. Ranst et al. (1998) mediram a CTC de solos com carga variável pela adsorção de $\mathrm{Ca}^{+2}$ $\left(\mathrm{CTC}_{\mathrm{B}}\right)$ e pela $\mathrm{CTC}_{\mathrm{T}}$, calculada pela adsorção de $\mathrm{Ca}^{+2}$ e $\mathrm{Al}^{+3}$. Valores de $\mathrm{CTC}$ a partir de métodos não tamponados são geralmente menores do que aqueles originados pelo método do acetato de amônio (pH 7), conforme Gillman (1979).

\subsubsection{Capacidade de troca aniônica}

A capacidade de retenção de ânions é um assunto bem menos conhecido e estudado do que a capacidade de troca catiônica, embora ambas dependam da natureza coloidal do solo. Solos ácidos de zonas tropicais podem apresentar CTA elevada devido a quantidades importantes de óxidos de ferro e alumínio, cujo comportamento químico é anfótero (Barrow, 1985). Solos com argilas cauliníticas, em condições de elevada acidez, podem apresentar carga elétrica positiva (Parfitt, 1978). Um bom entendimento da quantidade e distribuição de 
cargas pela superficie dos componentes do solo e de seus pontos de carga zero pode ser útil para explicar algumas propriedades químicas do solo, entre elas a CTA (Raij \& Peech, 1972; Gillman \& Sumpter, 1986).

A seqüência de adsorção geralmente considerada a série liotrópica aniônica, é: $\mathrm{NO}_{3}{ }^{-}=\mathrm{Cl}^{-}<\mathrm{SO}_{4}{ }^{-}<\mathrm{MoO}_{4}{ }^{-}<\mathrm{HPO}_{4}{ }^{-2}<\mathrm{H}_{2} \mathrm{PO}_{4}{ }^{-}<\mathrm{SiO}_{4}{ }^{-4}$ (Porta et al., 1999). Tal seletividade na adsorção de ânions pode nortear tentativas de melhorar a capacidade de assimilação de $\mathrm{P}$ em solos que hajam processos de fixação do elemento, como aplicação de insumos à base de silicatos de $\mathrm{Ca}$ e $\mathrm{Na}$. É indiscutível, também, a atuação que $\mathrm{o}^{-}$exerce na determinação da CTA. Óxidos de alumínio favorecem a adsorção de ânions devido à sua elevada superfície específica (100-220 $\left.\mathrm{m}^{2} \mathrm{~g}^{-1}\right)$, no caso dos amorfos, alto PCZ (5-9) e superfície de carga variável. McBride (1988) enfatizou que adsorção de ânions na superfície dos óxidos de alumínio está relacionada muito mais com a reatividade dos grupos $\mathrm{OH}^{-}$do que com a superfície específica. A alta fixação de $\mathrm{P}$ em Oxissols e Ultissols é usualmente relacionada com o conteúdo de gibbsita, além dos óxidos de Fe (Kämpf et al., 2000).

\subsubsection{Desenvolvimento de cargas}

A interação entre as partículas do solo, bem como a magnitude com que expressam as propriedades de troca e adsorção iônicas, estão estreitamente correlacionadas com a origem e natureza das cargas elétricas.

Cargas permanentes ou constantes são resultantes de substituição isomórfica, que ocorre principalmente em minerais do tipo $2: 1$, ao passo que protonação/desprotonação e adsorção específica de íons respondem pelas cargas variáveis ou dependentes do $\mathrm{pH}$. Zhang \& Zhao (1997) mencionaram que a caulinita, mesmo sendo um argilomineral de grade $1: 1$, pode ser provida de carga permanente ao ocorrer substituição isomórfica do silício tetravalente por alumínio 
trivalente. Sposito (1989) estimou em $20 \mathrm{mmol}_{\mathrm{c}} \mathrm{kg}^{-1}$ a contribuição da substituição isomórfica para a geração de cargas permanentes nestes compostos. Contudo, $\mathrm{Yu}$ (1997) mencionou que as cargas negativas permanenntes da caulinita, em condições tropicais e subtropicais, podem variar de 30 a $100 \mathrm{mmol}_{\mathrm{c}}$ $\mathrm{kg}^{-1}$. Em caso de intemperismo intenso, cargas permanentes, mesmo que pouco atuantes, podem resultar de substituições isomórficas do alumínio trivalente por magnésio bivalente em gibbsita, no caso de óxidos de alumínio, e de ferro trivalente por magnésio divalente em óxidos de ferro (Olson et al., 2000).

As arestas quebradas de argilominerais, matéria orgânica e óxidos hidratados de $\mathrm{Fe}$ e $\mathrm{Al}$ são fontes de carga elétrica variável por terem maior habilidade em complexar íons $\mathrm{H}^{+}$e $\mathrm{OH}^{-}$, conferida pelos seus grupos funcionais de superficie (Sposito, 1989; Hillier, 1995; Yu ,1997).

Em solos tropicais altamente intemperizados, os óxidos/hidróxidos e silicatos de grade 1:1 têm especial significância, não somente pela sua grande quantidade, mas também pela variabilidade na sua superficie de carga (Ranst et al., 1998; Olson et al, 2000). Estes compostos exibem comportamento anfótero, governado pelo $\mathrm{pH}$ e concentração eletrolítica da solução do solo (Uehara \& Gillman, 1980).

\subsubsection{Influência dos óxidos na determinação da CTC e CTA}

A abundante presença de $\mathrm{Al}, \mathrm{Fe}$ e $\mathrm{Mn}$ na litosfera se deve a baixa solubilidade de suas formas em condições normais de $\mathrm{pH}$. Dentre os principais oxihidróxidos encontrados em solos sob condições tropicais, destacam-se a gibbsita e boemita, como compostos de $\mathrm{Al}$, e goetita, hematita, lepidocrocita, maghemita e magnetita como compostos de Fe (Schwertmann \& Taylor, 1989; Sposito, 1989), que ocorrem na fração argila, como partículas discretas, ou como recobrimento de grãos de silte e areia (Olson et al., 2000; Goldberg et al., 2000). 
As posições de troca de cátions da caulinita podem ter suas cargas negativas bloqueadas pelos óxidos de ferro (Grim, 1963). Após a remoção dos óxidos de ferro, exceto sob condições muito ácidas, cargas positivas praticamente desaparecem. Dion (1944), ao remover óxidos de ferro do solo, constatou acréscimo de 10 a 59\% na CTC. Raij (1967) obteve aumento na CTC, após a remoção de óxidos de ferro livres, variando de 0 a $74 \%$.

\subsubsection{Efeitos da matéria orgânica sobre a troca iônica}

É indiscutível a contribuição da matéria orgânica para a CTC do solo, mesmo quando presente em quantidades relativamente baixas. São diversas as interações entre os componentes orgânicos e inorgânicos do solo (Baldock \& Nelson, 2000). Tan (1993) e Yu (1997) mencionaram a redução da carga superficial total do complexo organo-mineral (caulinita-matéria orgânica) quando comparada à soma de suas contribuições separadamente. As condições climáticas dos trópicos catalisam a decomposição de materiais orgânicos (Stevenson, 1994). Dessa forma, a quantidade de húmus presente em solos tropicais é considerável e serve de argumento para Yu (1997) desconsiderar o efeito sinérgico da CTC das frações orgânica e inorgânica. A precipitação do húmus, cuja carga negativa varia de 2000 a $5000 \mathrm{mmol}_{\mathrm{c}} \mathrm{kg}^{-1}$, pode bloquear sítios de cargas negativas dos colóides minerais. Turpault et al. (1996) mostraram que a CTC da matéria orgânica, calculada em amostras de horizontes superficiais $(0-0,20 \mathrm{~m})$ de solos ácidos $(\mathrm{pH}$ em água 3,4 a 4,0), estava entre 350 e $1050 \mathrm{mmol}_{\mathrm{c}} \mathrm{kg}^{-1}$, representando entre $10 \mathrm{a}$ $85 \%$ da CTC total da terra fina. Estes valores são considerados baixos, visto o grau de decomposição que o material orgânica pode atingir, e podem ser atribuídos ao fato dos grupos carboxílicos da matéria orgânica estarem amplamente indissociados em condições de baixo $\mathrm{pH}$ destes solos. 


\section{4 pH de abrasão}

$\mathrm{O}$ mais importante processo de intemperismo químico em silicatos $\mathrm{e}$ aluminossilicatos é a hidrólise. A água, na qual uma variedade de íons pode estar presente, reage com estes minerais, atuando como principal agente desagregador de estruturas de minerais e, apesar da dissociação iônica ser pequena $\left(10^{-7} \mathrm{~g} \mathrm{de} \mathrm{H}^{+}\right.$ $\mathrm{L}^{-1}$ de $\mathrm{H}_{2} \mathrm{O}$ ), a enorme quantidade de água na natureza acaba provocando reações hidrolíticas de grande intensidade. Os produtos comuns da hidrólise são $\mathrm{H}_{4} \mathrm{SiO}_{4}$, $\mathrm{HCO}_{3}{ }^{-}$e $\mathrm{OH}^{-}$, junto com minerais de argila se o alumínio estiver presente em minerais decomponíveis e se certas condições químicas são encontradas (Rai \& Kittrick, 1989).

Um efeito da reação de hidrólise é que o ion hidrogênio é consumido, hidróxido é produzido, e a solução torna-se mais básica. O processo de substituição de parte dos cátions por hidrogênio continua até o ponto em que o estado de equilíbrio seja alcançado (Loughnan, 1969).

$$
\mathrm{M}^{+} \text {[mineral] }+\mathrm{H}^{+} \mathrm{OH}^{-} \leftrightarrow \mathrm{H}^{+} \text {[mineral }{ }^{-}+\mathrm{M}^{+} \mathrm{OH}^{-}
$$

Este mecanismo responde pelo empobrecimento dos minerais primários em relação aos cátions mais móveis, que ao permanecerem em solução, elevam o $\mathrm{pH}$ da fase líquida (Figura 1). Este efeito é especialmente notado quando vários silicatos e aluminossilicatos são moídos em água destilada, e o pH da solução, chamado $\mathrm{pH}$ de abrasão, é obtido. Este $\mathrm{pH}$ resultante da hidrólise inicial é função da rapidez com a qual os cátions são liberados para a solução e com que as bases são formadas. $\mathrm{O}$ pH de abrasão do material intemperizado, que inclui algumas argilas, é menor do que o $\mathrm{pH}$ da rocha original, devido a alguns cátions terem sido removidos, e o pH de abrasão de alguns minerais de argila comumente é menor do que aqueles minerais formados da rocha (Grant, 1969). 


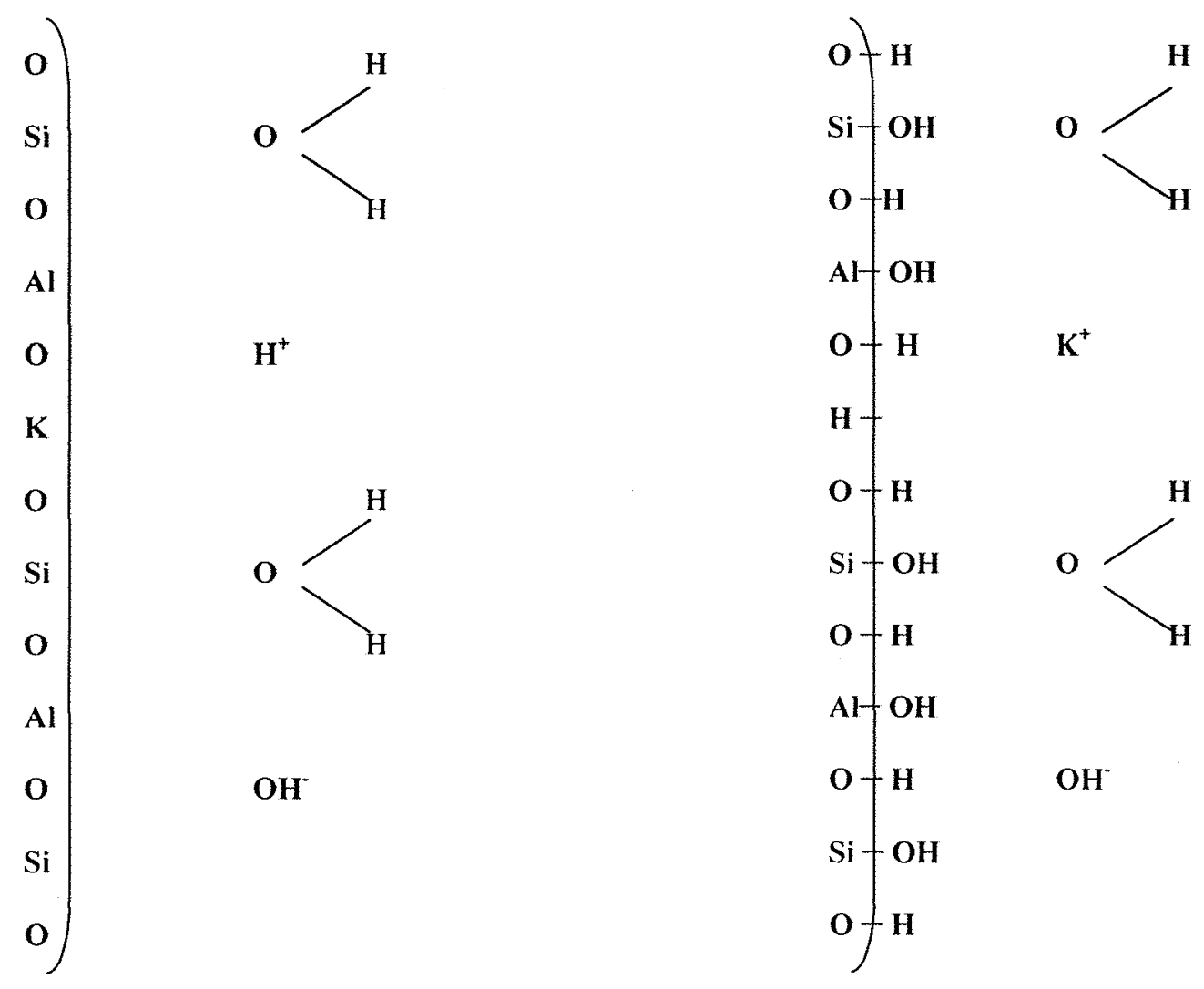

Figura 1. Remoção de cátions da superfície de minerais, substituídos por $\mathrm{H}^{+}$ (Olier, 1969).

O grau de intemperização química é estimado por meio de índices, que levam em consideração o deslocamento de minerais decomponíveis, bem como a mobilidade de cátions liberados da estrutura cristalina dos minerais (Herbillon \& Makumbi, 1975). Desse modo, o pH de abrasão funciona como importante artifício na determinação do grau de intemperismo dos solos (Grant, 1969; Ferrari \& Magaldi, 1983; Taboada et al., 1990) pela reação e variação do pH da solução 
inerente a determinado mineral. Logo, cada mineral, quando pulverizado e colocado em contato com a água, confere à solução um determinado valor de pH (Tabela 1).

Tabela 1. Diferentes minerais e respectivos valores de pH de abrasão (adaptada de Olier (1969) e Birkeland (1974)).

\begin{tabular}{|c|c|c|}
\hline Minerais & Fórmula & pH de abrasão \\
\hline $\begin{array}{l}\text { silicatos } \\
\text { olivina }\end{array}$ & $(\mathrm{Mg}, \mathrm{Fe})_{2} \mathrm{SiO}_{4}$ & $10-11$ \\
\hline augita & $\mathrm{Ca}(\mathrm{Mg}, \mathrm{Fe}, \mathrm{Al})(\mathrm{Al}, \mathrm{Si})_{2} \mathrm{O}_{6}$ & 10 \\
\hline hornblenda & $\mathrm{Ca}_{2} \mathrm{Na}(\mathrm{Mg}, \mathrm{Fe})_{4}\left(\mathrm{Al}, \mathrm{Fe}, \mathrm{Ti}_{3}\right)_{3} \mathrm{Si}_{6} \mathrm{O}_{22}(\mathrm{O}, \mathrm{OH})_{2}$ & 10 \\
\hline albita & $\mathrm{NaAISi}_{3} \mathrm{O}_{8}$ & $9-10$ \\
\hline oligoclásio* & $A b_{90-70} A n_{10-30}$ & 9 \\
\hline labradorita* & $A b_{50-30} A n_{50-70}$ & $8-9$ \\
\hline biotita & $\mathrm{K}(\mathrm{Mg}, \mathrm{Fe})_{3} \mathrm{AlSi}_{3} \mathrm{O}_{10}(\mathrm{OH})_{2}$ & $8-9$ \\
\hline microclina & $\mathrm{KAISi}_{3} \mathrm{O}_{8}$ & $8-9$ \\
\hline anortita & $\mathrm{CaAl}_{2} \mathrm{Si}_{2} \mathrm{O}_{8}$ & 8 \\
\hline hiperstena & $(\mathrm{Mg}, \mathrm{Fe})_{2} \mathrm{Si}_{2} \mathrm{O}_{6}$ & 8 \\
\hline muscovita & $\mathrm{KAl}_{3} \mathrm{Si}_{3} \mathrm{O}_{10}(\mathrm{OH})_{2}$ & $7-8$ \\
\hline ortoclásio & $\mathrm{KAISi}_{3} \mathrm{O}_{6}$ & 8 \\
\hline montmorilonita & $\left(\mathrm{Al}_{2}, \mathrm{Mg}_{3}\right) \mathrm{Si}_{4} \mathrm{O}_{10}(\mathrm{OH})_{2} \cdot n \mathrm{H}_{2} \mathrm{O}$ & $6-7$ \\
\hline haloisita & $\mathrm{Al}_{2} \mathrm{Si}_{2} \mathrm{O}_{5}(\mathrm{OH})_{4}$ & 6 \\
\hline caulinita & $\mathrm{Al}_{2} \mathrm{Si}_{2} \mathrm{O}_{5}(\mathrm{OH})_{4}$ & $5-7$ \\
\hline \multicolumn{3}{|l|}{ óxidos } \\
\hline boemita & $\mathrm{AlO}(\mathrm{OH})$ & $6-7$ \\
\hline gibbsita & $\mathrm{Al}(\mathrm{OH})_{3}$ & $6-7$ \\
\hline quartzo & $\mathrm{SiO}_{2}$ & $6-7$ \\
\hline hematita & $\mathrm{Fe}_{2} \mathrm{O}_{3}$ & 6 \\
\hline \multicolumn{3}{|l|}{ carbonatos } \\
\hline dolomita & $\mathrm{CaMg}\left(\mathrm{CO}_{3}\right)_{2}$ & $9-10$ \\
\hline calcita & $\mathrm{CaCO}_{3}$ & 8 \\
\hline
\end{tabular}

*Ab = albita; $\mathrm{An}=$ anortita

Entretanto, são escassos os trabalhos que estabelecem um vínculo entre este valor e outros atributos que afetam a fertilidade do solo, exceção feita ao de Ferrari \& Magaldi (1983), que propuseram um índice derivado da diferença entre o $\mathrm{pH}$ de abrasão e o $\mathrm{pH}$ do solo $\left(\mathrm{DpH}=\mathrm{pH}_{\text {abrasão }}-\mathrm{pH}_{\text {solo }}\right)$. De acordo com os 
valores de $\mathrm{DpH}$, os autores inferiram o grau de intemperização dos solos e sua reserva mineral (Tabela 2 ).

Tabela 2. Relação entre $\mathrm{DpH}$, classes de intemperização e fertilidade potencial (Ferrari \& Magaldi, 1983)

\begin{tabular}{ccc}
\hline DpH & Reservas minerais & Grau de intemperização \\
\hline$>1,9$ & Baixa $-<950$ & Alto \\
$1,9-0,2$ & Média -950 a 1700 & Moderado \\
$<0,2$ & Alta $->1700$ & Baixo \\
\hline
\end{tabular}

Mais recentemente Romero et al. (1987) ${ }^{1}$, citados por Taboada et al. (1990), consideraram o pH de abrasão da fração areia um índice para a determinação da fertilidade potencial do solo, pela indicação da presença de minerais potencialmente alteráveis.

\footnotetext{
' ROMERO, R.; TABOADA, T; GARCÍA, C.; MACÍAS, F. Utilización del pH de abrasión como um indice del grado de evolución de la alteración y edafogénesis en suelos graníticos de la provincia de La Coruña. Cuad. Lab. Xeol. De Laxe, v.11, p.171-182, 1987.
} 


\section{MATERIAL E MÉTODOS}

As análises químicas e físicas foram executadas nos Laboratórios do Departamento de Solos e Nutrição de Plantas, e as análises mineralógicas foram realizadas no Núcleo de Pesquisa em Geoquímica e Geofísica da Litosfera (NUPEGEL), da Escola Superior de Agricultura "Luiz de Queiroz" (ESALQ/USP).

\subsection{Solos}

Foram retiradas amostras superficiais, representativas do horizonte $\mathrm{A}$, e subsuperficiais, na maior expressão do horizonte diagnóstico, de alguns solos geográfica e economicamente representativos da região Sudeste do Brasil (Tabela 3), classificados de acordo com o Sistema Brasileiro de Classificação de Solos (Embrapa, 1999). A amostragem foi realizada em duas profundidades, considerando possíveis variações texturais e diferentes contribuições das frações granulométricas dentro da camada mais explorada pela maioria das culturas. Além disso, em solos intemperizados dos trópicos, observam-se contrastes marcantes ao longo do perfil em relação à CTC, propriedade governada em grande parte pela matéria orgânica, cuja maior expressão se verifica nas camadas superficiais. 
Tabela 3. Solos estudados e locais de amostragem.

\begin{tabular}{lll}
\hline \multicolumn{1}{c}{ Solos } & Simbologia & \multicolumn{1}{c}{ Local } \\
\hline LATOSSOLO AMARELO Ácrico & LAw-1 & Uberlândia/MG \\
LATOSSOLO VERMELHO-AMARELO Ácrico & LVAw & Uberlândia/MG \\
LATOSSOLO VERMELHO Ácrico & LVw & Uberlândia/MG \\
LATOSSOLO AMARELO Ácrico & LAw-2 & Guaíra/SP \\
LATOSSOLO VERMELHO Acriférrico & LVwf & Ribeirão Preto/SP \\
NITOSSOLO VERMELHO Eutroférrico & NVef & Ribeirão Preto/SP \\
NEOSSOLO QUARTZARÊNICO Órtico & RQo & São Pedro/SP \\
NEOSSOLO LITÓLICO Eutrófico & RLe & Piracicaba/SP \\
CAMBISSOLO HÁPLICO Tb Distrófico & CXbd-1 & Prados/MG \\
CAMBISSOLO HÁPLICO Tb Distrófico & CXbd-2 & São João del Rei/MG \\
PLINTOSSOLO HÁPLICO Distrófico & FXd & Prados/MG \\
ARGISSOLO VERMELHO-AMARELO Distrófico & PVAd & Piracicaba/SP \\
\hline \hline
\end{tabular}

\subsection{Geologia da região Sudeste}

A região Sudeste é caracterizada pelo clima quente e úmido, com seca no inverno, relevo que varia desde plano a montanhoso e vegetação primária representada por formações pioneiras sob influência flúvio marinha, floresta ombrófila semidecidual e decidual e cerrado (RADAMBRASIL, 1986). O mapa geológico aponta a ocorrência de diversas litologias, incluindo aquelas que representam o material de origem dos solos estudados. A manifestação de diversas propriedades de interesse para a fertilidade dos solos é dependente da constituição mineralógica do material de origem e do seu grau de alteração. Sendo assim, uma descrição sucinta do material de origem dos solos é oportuna (Tabela 4). 
Tabela 4. Material de origem dos solos estudados.

\begin{tabular}{cccc}
\hline Solo & Material de origem & Grupo & Formação \\
\hline EAw-1 & $\begin{array}{c}\text { cobertura detrito- } \\
\text { latossólica argilosa }\end{array}$ & Era Cenozóica & Terciário / Quaternário \\
LVAw & arenito & Bauru & Marilia/Adamantina \\
GVw & cobertura detrito- & Era Cenozóica & Terciário / Quaternário \\
LAw-2 & latossólica argilosa & São Bento & Serra Geral \\
LVwf & basalto & São Bento & Serra Geral \\
NVef & basalto & São Bento & Serra Geral \\
RQo & arenito & São Bento & Pirambóia \\
RLe & folhelho siltoso / siltito & Passa Dois & Corumbataí \\
CXbd-1 & metapelitos, & São João del Rei & Prados \\
CXbd-2 & metassiltitos e filitos & Sarambóia \\
FXd & micaxisto & São João del Rei & Caranaíba \\
PVAd & siltito & São Bento & Prados \\
\hline \hline
\end{tabular}

Em Minas Gerais, o Grupo São João del Rei comporta, principalmente, rochas que sofreram intenso metamorfismo, sendo descrito como um pacote de metassedimentos de fáceis xisto-verde (Ebert, 1967), cujas principais Formações para este estudo são:

- Formação Carandaí : composta por um metaconglomerado basal, supostamente glacial, e metassiltitos grafitosos; a leste de São João del Rei é constituída por xistos com intercalações quartzíticas.

. Formação Prados : inclui filitos bandados, siltitos e arenitos. 
O LVw e o LAw-1, coletados no município de Uberlândia, estão localizados no ápice da Chapada Sul-Americana. De acordo com a coluna litoestratigráfica do Triângulo Mineiro (Baccaro, 1991), estes solos desenvolveram-se sobre sedimentos inconsolidados do período TerciárioQuaternário, sendo portanto pouco provável sua formação in situ, uma vez que o material subjacente é um arenito do Grupo Bauru, que aflora nas proximidades do Rio Paranaíba, local onde predomina o LVAw.

Os solos coletados no Estado de São Paulo estão distribuídos dentro da Bacia do Paraná, importante feição tectônica que ocupa em torno de $70 \%$ da área estadual e que é representada por rochas datadas do Paleozóico. O principal conjunto de rochas do Grupo Passa Dois para este estudo é a Formação Corumbataí, composta por siltitos, argilitos e folhelhos de coloração cinza a arroxeada, podendo possuir cimentação carbonática, sucedidos por camadas siltosas.

O ambiente de formação do Grupo São Bento foi marcado pelo início e término da retirada das águas marinhas, caracterizando um período de transição entre ambiente aquoso e desértico. Desta forma, sedimentação foi o principal processo de gênese das rochas deste Grupo, embora magmatismo intenso tenha ocorrido dando origem a rochas extrusivas que permeiam as sedimentares em grandes extensões. As principais Formações estudadas estão descritas a seguir, de acordo com Schobbenhaus et al. (1984):

- Formação Pirambóia : composta por arenitos de granulação média a fina cimentados por argila.

- Formação Serra Geral : caracterizada por eventos deposicionais vulcânicos (diques e sills de diabásio), é composta estritamente por rochas básicas e ultrabásicas.

O fim dos derrames basálticos na Bacia do Paraná foi marcado pelo início de uma fase de embaciamento, área onde se acumulou o Grupo Bauru, gerado a 
partir do retrabalhamento das rochas do grupo São Bento. As formações que se incluem neste trabalho são (Schobbenhaus et al., 1984):

- Formação Adamantina : arenitos de granulação fina a muito fina, com cimentação por argila, óxidos de ferro e sílica.

. Formação Marília : arenitos grosseiros a conglomeráticos com forte cimentação carbonática.

\subsection{Preparo das amostras}

As amostras passaram por um tratamento inicial seguindo o método proposto pela Embrapa (1997), que consiste do espalhamento e destorroamento manual, em local ventilado e seco, para que as amostras alcancem a completa dessecação ao ar para serem, então, pesadas. Manualmente, as amostras foram suavemente pressionadas com um rolo de madeira para a destruição dos torrões maiores e separação da fração grosseira. Após o destorroamento, foram tamisadas em um conjunto de duas peneiras sobrepostas, sendo a superior de malha $20 \mathrm{~mm}$, que retém o material denominado calhaus, e a inferior de malha $2 \mathrm{~mm}$, onde ficam retidos os cascalhos. Sobre a peneira de $2 \mathrm{~mm}$, ambas as frações foram lavadas com água corrente. $\mathrm{O}$ material que transpôs as duas peneiras compõe a terra fina.

\subsection{Terra fina}

\subsubsection{Separação das frações granulométricas}

Os métodos empregados na separação das frações granulométricas estão descritos em Jackson (1969) e Camargo et al. (1986). Ao volume equivalente a 50 $\mathrm{g}$ de terra fina seca ao ar (TFSA) foram adicionados $250 \mathrm{~mL}$ de solução 
dispersante, composta por hexametafosfato de sódio e hidróxido de sódio. O conjunto foi submetido à agitação mecânica intensa por um período de 24 horas e então vertido em peneira de abertura $0,053 \mathrm{~mm}$, que assegura a retenção da areia total. A areia total foi seca em estufa a $60-70^{\circ} \mathrm{C}$, sendo então processada em agitador-peneirador composto por um conjunto de peneiras $(1,0-0,5-0,25$ $0,105 \mathrm{~mm}$ ) e um controlador de velocidade de rotação, que padroniza a intensidade de agitação. Após 1 minuto, obtiveram-se cinco subfrações de areia, em concordância com a escala proposta pelo Departamento de Agricultura do Estados Unidos (Figura 2).

\begin{tabular}{|c|c|c|c|c|c|c|c|}
\hline 0,0 & & & & & 0,50 & & $\mathbf{m m}$ \\
\hline \multirow[b]{2}{*}{ ARGILA } & \multirow[b]{2}{*}{ SILTE } & Muito Fina & Fina & Média & Grossa & Muito Grossa & \multirow[b]{2}{*}{ CASCALHO } \\
\hline & & \multicolumn{5}{|c|}{ AREIA } & \\
\hline
\end{tabular}

Figura 2. Classificação das partículas do solo, de acordo com os tamanhos em mm, segundo o Departamento de Agricultura dos Estados Unidos (USDA, 1975).

A suspensão, contendo argila e silte, foi recolhida em proveta com capacidade para $1 \mathrm{~L}$ e deixada em repouso para decantação. Por vezes, optou-se pela adição de $50 \mathrm{~mL}$ de $\mathrm{HCl} 10 \%$ para acelerar este processo. Após a decantação, sifonou-se o excesso da fase líquida mantendo a argila e o silte na proveta. O período de decantação, assegurado pela lei de Stokes, possibilitou a deposição total do silte. A suspensão foi recolhida em becker até a observação do silte depositado no fundo da proveta. Esta suspensão, contendo exclusivamente argila, foi acondicionada em cápsulas de porcelana e levada à estufa para secagem a $60-70^{\circ} \mathrm{C}$. O material restante, contendo silte e argila, foi recolhido em tubos de polietileno. A centrifugação por 3 minutos a $700 \mathrm{rpm}$ assegura a deposição do 
silte (Jackson,1969), mantendo a argila em suspensão, que por sua vez pode ser descartada ou recolhida novamente em cápsula de porcelana. Centrifugou-se o material até a limpidez da suspensão, momento em que o silte foi recolhido em cápsula de porcelana para a secagem em estufa a $60-70^{\circ} \mathrm{C}$.

\subsubsection{Pré-tratamentos}

\subsubsection{Eliminação da matéria orgânica}

O estudo dos componentes inorgânicos do solo requer sempre um prétratamento para a eliminação da matéria orgânica. Embora o peróxido de hidrogênio seja considerado o extrator de máxima destruição da matéria orgânica, vários problemas estão associados ao seu uso como pré-tratamento de amostras. Drosdoff \& Milles (1938) perceberam que o $\mathrm{H}_{2} \mathrm{O}_{2}$ causava a exfoliação da mica, pela penetração do reagente nas lâminas do mineral que, teoricamente, não se expandem com água e nem com outras substâncias orgânicas (Porta et al., 1999). Vários autores apontaram a formação de oxalato de cálcio em solos pelo tratamento com peróxido de hidrogênio (Bourget \& Tanner, 1953; Martin, 1954; Farmer \& Mitchell, 1963). Jackson (1969) mostrou que a peroxidação da matéria orgânica possivelmente leva à dissolução de $\mathrm{MnO}_{2}$ e parece solubilizar grande quantidade de ferro e alumínio. Consideráveis quantidades de complexos oxalatoférricos e oxalato-alumínicos foram detectados por Farmer \& Mitchell (1963) em extratos de peróxido, especialmente em argilas com alto conteúdo de componentes amorfos. Mitchell et al. (1964) notificaram que todo material amorfo está sujeito ao ataque e alteração pela atuação do peróxido. Turpault et al. (1996) notou perda de massa maior do que a massa da matéria orgânica destruída, 
atribuída a dissolução de minerais durante o tratamento com $\mathrm{H}_{2} \mathrm{O}_{2}$, gerando dados superestimados da CTC.

$\mathrm{Na}$ busca de alternativas que substituíssem o método de peroxidação da matéria orgânica como pré-tratamento para análise mineralógica, Anderson (1961) empregou o método do hipoclorito de sódio, descrito por Bourget \& Tanner (1953). O autor sugeriu o uso de soluções de $\mathrm{NaOCl}$, ajustadas a pH 9,5, para a destruição da matéria orgânica. Ele indicou que o $\mathrm{NaOCl}$ foi mais efetivo na destruição da matéria orgânica do que o peróxido e que o $\mathrm{NaOCl}$ foi menos destrutivo para sesquióxidos, sílica e componentes de argila cristalina.

Ao realizarem um estudo comparativo entre o peróxido de hidrogênio e o hipoclorito de sódio quanto à efetividade na destruição da matéria orgânica, Lavkulich \& Wiens (1970) obtiveram resultados que corroboraram os apontamentos de Anderson (1961) e que confirmaram a maior destruição da matéria orgânica com a mínima destruição de óxidos e minerais identificáveis pelo uso da solução $\mathrm{NaOCl}$ a pH 9,5. Assim como Anderson (1961), Lavkulich e Wiens (1970) verificaram que três tratamentos com $\mathrm{NaOCl}$ foram suficientes para eliminar $98 \%$ do carbono oxidável do solo, sendo que a adição de mais tratamentos apresentou resultados desprezíveis em relação à destruição da matéria orgânica e conseqüências indesejáveis para a fração mineral.

Desta maneira, para a eliminação da matéria orgânica, como prétratamento das amostras, foi seguido o método descrito por Lavkulich e Wiens (1970) : preparou-se a solução de hipoclorito de sódio transferindo-se $500 \mathrm{~mL}$ do produto comercial $(12 \%$ de $\mathrm{Cl})$ para bécker de $1 \mathrm{~L}$, volume ao qual adicionaramse $400 \mathrm{~mL}$ de água destilada. Em seguida, mediu-se o pH (que sempre estará em torno de 12,0 ) e, mantendo o eletrodo imerso na solução, procedeu-se a correção do $\mathrm{pH}$ da solução, mantida sob agitação pelo uso do agitador magnético, mediante a adição de $\mathrm{HCl}$ concentrado. Ao atingir pH 9,5, transferiu-se a solução para balão de $1 \mathrm{~L}$ e completou-se o volume para a obtenção de uma solução com $6 \%$ 
de $\mathrm{Cl}$. A $10 \mathrm{~g}$ de amostra, acondicionada em tubo de centrífuga, adicionaram-se $20 \mathrm{~mL}$ de solução $\mathrm{NaOCl}$ a pH 9,5. O conjunto foi levado para aquecimento em banho-maria por 15 minutos a $90-95^{\circ} \mathrm{C}$ e submetido a agitações com bastão de vidro a cada cinco minutos. Centrifugou-se e descartou-se o sobrenadante. Repetiram-se estas operações por mais duas vezes. A remoção da matéria orgânica foi evidenciada pela mudança de cor do sobrenadante, a qual tornou-se incolor, cinza ou vermelha (Moore \& Reynolds, 1989).

\subsubsection{Deferrificação}

A remoção dos óxidos de ferro livres (hematita, goetita, lepidocrocita) facilita a dispersão dos materiais do solo e das suas diversas frações, pois evita o aprisionamento mecânico de partículas de argila nos materiais de maiores dimensões (Mehra \& Jackson, 1960; Ghabru et al., 1990). É procedimento considerado essencial para a identificação mineralógica da areia e do silte, por remover a camada de recobrimento, além de intensificar os feixes difratados que discriminam os distintos argilominerais (Moore \& Reynolds, 1989). Para tanto, pesou-se uma amostra de solo contendo um máximo estimado de 0,5 g de $\mathrm{Fe}_{2} \mathrm{O}_{3} \mathrm{e}$ isenta de matéria orgânica, eliminada pelo método do hipoclorito de sódio. Adicionaram-se $40 \mathrm{~mL}$ de citrato de sódio $0,3 \mathrm{~mol} \mathrm{~L}^{-1}$ e $5 \mathrm{~mL}$ de $\mathrm{NaHCO}_{3} 1 \mathrm{~mol}$

$\mathrm{L}^{-1}$ à amostra contida em tubo de centrífuga e, após agitação, aqueceu-se até a faixa de $75-80^{\circ} \mathrm{C}$, temperatura em que a amostra esteve pronta para receber $1 \mathrm{~g}$ de ditionito de sódio e ser submetida a agitação intensa, com bastão de vidro, por um minuto. Manteve-se o aquecimento por uma hora, intervalo no qual várias agitações foram necessárias. Repetiu-se a adição de ditionito de sódio, aguardando mais meia hora. Após conclusão dos tratamentos, adicionaram-se 10 $\mathrm{mL}$ de solução de cloreto de sódio saturada, misturou-se e centrifugou-se. Transferiu-se a solução para balão volumétrico de $250 \mathrm{~mL}$ cujo volume foi 
completado após o recolhimento do resíduo resultante de mais duas lavagens com $\mathrm{NaCl}$ 0,5 mol L $\mathrm{L}^{-1}$ (Jackson, 1969). Esta solução foi utilizada na determinação do Fe livre, cuja metodologia está resumida em outro ítem desta dissertação. Tal procedimento foi aplicado em todas as frações em que a CTC, CTA, pH de abrasão e preparo de lâminas para raios-X foram objeto de estudo.

\subsubsection{Análises químicas, físicas e mineralógicas}

Métodos segundo Camargo et al. (1986), que se resumem em seguida:

\subsubsection{Análises químicas de rotina e complementares}

- Carbono orgânico (\% C): oxidação da matéria orgânica do solo com solução de dicromato de potássio em presença de ácido sulfúrico e titulação do excesso de dicromato com sulfato ferroso amoniacal. A estimativa do conteúdo de matéria orgânica foi calculada pela equação: \%M.O. $=\% \mathrm{C} \times 1,725$.

- Cátions trocáveis: extração das bases trocáveis $(\mathrm{Ca}, \mathrm{Mg}, \mathrm{K}, \mathrm{Na})$ com solução normal de acetato de amônio a pH 7,0 e determinação de seus teores nos extratos. Acidez trocável (Al) usando $\mathrm{KCl} 1 \mathrm{~mol} \mathrm{~L}^{-1}$ como extrator. Acidez potencial $(\mathrm{H}+\mathrm{Al})$ extraída por acetato de cálcio a $\mathrm{pH} 7,0$.

- pH em $\mathrm{H}_{2} \mathrm{O}$, em $\mathrm{CaCl}_{2} 0,01 \mathrm{~mol} \mathrm{~L} L^{I}$ e em $\mathrm{KCl} 1 \mathrm{~mol} \mathrm{~L}^{-1}$ : relação solo-solução 1:2,5 e obtenção dos valores pela medida da variação do potencial em um eletrodo de vidro com a variação da atividade hidrogeniônica da solução em que ele está mergulhado, usando um eletrodo de referência.

- Ferro livre (solúvel em solução ditionito-citrato-bicarbonato(DCB)): em meio tamponado com bicarbonato de sódio $\mathrm{pH} 7,3$, ferro foi reduzido pelo ditionito de sódio e complexado pelo citrato de sódio, permanecendo em solução, obtida conforme citado no ítem 3.4.2.2. Do balão de $250 \mathrm{~mL}$, recolheu-se uma alíquota 
de $1 \mathrm{~mL}$ e transferiu-se para balão de $100 \mathrm{~mL}$. Acrescentou-se água até a metade do balão, uma pitada de ácido ascórbico (aproximadamente $30 \mathrm{mg}$ ), $5 \mathrm{~mL}$ de 110-o-fenantrolina a $0,25 \%$ e $2 \mathrm{~mL}$ da solução de citrato de sódio a $25 \%$. Completou-se o volume e agitou-se. Procedeu-se a leitura em espectrofotômetro a $518 \mathrm{~nm}$, após quinze minutos de repouso.

- Ferro mal cristalizado: obtido por solubilização do ferro amorfo em ácido oxálico e seu sal de amônio. O método se processou em ambiente com total ausência de luz, de acordo com o seguinte procedimento: pesou-se $0,5 \mathrm{~g}$ de amostra em tubo de centrífuga envolto com papel alumínio e adicionaram-se 50 $\mathrm{mL}$ da solução de Tamm (solução de ácido oxálico e oxalato de amônio ajustada para pH 3,0). Após 4 horas de agitação, centrifugou-se a $1000 \mathrm{rpm}$, durante 10 minutos e transferiu-se o sobrenadante para balão volumétrico de $250 \mathrm{~mL}$, cujo volume foi completado. Diluiram-se $10 \mathrm{~mL}$ do extrato em balão volumétrico de $100 \mathrm{~mL}$ com água deionizada e procederam-se as leituras em espectrofotômetro de absorção atômica (AAS).

- Teores de óxidos $\left(\mathrm{SiO}_{2}, \mathrm{Al}_{2} \mathrm{O}_{3}, \mathrm{Fe}_{2} \mathrm{O}_{3}, \mathrm{TiO}_{2}\right.$ e $\mathrm{MnO}$ ): obtidos pelo ataque com ácido sulfúrico

Destas determinações originaram-se os seguintes valores:

. Soma de bases $(\mathrm{SB}): \mathrm{Ca}+\mathrm{Mg}+\mathrm{K}+\mathrm{Na}$

- Capacidade de troca de cátions efetiva $\left(C T C_{e}\right): \mathrm{SB}+\mathrm{Al}$

- Capacidade de troca de cátions total $(C T C): \mathrm{SB}+(\mathrm{H}+\mathrm{Al})$

. Porcentagem de saturação por bases (V\%) : $\mathrm{SB} \times 100 / \mathrm{CTC}_{\mathrm{t}}$

. $\Delta p H=\mathrm{pH} \mathrm{KCl}-\mathrm{pH} \mathrm{H} \mathrm{H}_{2} \mathrm{O}$.

. Indice $\mathrm{Ki}=\left(\mathrm{SiO}_{2} / 60\right) /\left(\mathrm{Al}_{2} \mathrm{O}_{3} / 102\right)$

. Indice $\mathrm{Kr}=\left(\mathrm{SiO}_{2} / 60\right) /\left[\left(\mathrm{Al}_{2} \mathrm{O}_{3} / 102\right)+\left(\mathrm{Fe}_{2} \mathrm{O}_{3} / 106\right)\right]$

\subsubsection{Análises físicas}


- Análise granulométrica: pelo método do densímetro. Tomaram-se $20 \mathrm{~g}$ de terra aos quais adicionaram-se $100 \mathrm{~mL}$ de solução dispersante (hexametafosfato de sódio e hidróxido de sódio). Agitou-se o conjunto em agitor mecânico horizontal por 16 horas a $30 \mathrm{rpm}$. Verteu-se toda a suspensão em peneira $0,053 \mathrm{~mm}$ para recolhimento da areia total, recolheu-se a suspensão em proveta calibrada com capacidade para $1 \mathrm{~L}$ e completou-se o volume com água destilada. Agitou-se a amostra com haste manual por 40 segundos e após 40 segundos de repouso, inseriu-se $o$ densímetro na suspensão e efetivou-se a primeira leitura correspondente a silte + argila. Após novo repouso por duas horas, realizou-se a segunda leitura que corresponde à fração argila. Por diferença, os separados até $0,05 \mathrm{~mm}$ foram estimados. Secou-se a areia em estufa à $60^{\circ} \mathrm{C}$ e determinou-se 5 subfrações pelo uso de peneiras $(1,0-0,5-0,25-0,105 \mathrm{~mm})$ conforme a classificação proposta pelo Departamento de Agricultura dos Estados Unidos.

- Argila dispersa em água: determinação da fração <0,002 mm na ausência de eletrólitos. A porcentagem de argila dispersa em água foi estimada pelas seguintes equações:

- Grau de floculação $=100$ (argila total - argila dispersa em água) / argila total)

. Grau de dispersão $=100-$ grau de floculação

\subsubsection{Análise mineralógica qualitativa}

- argila: foram utilizadas amostras de argila previamente tratadas, para eliminação da matéria orgânica e dos óxidos de ferro, e com auxílio da difração de raios-X foram feitas determinações qualitativas nas amostras saturadas com $\mathrm{Mg}^{2+}$, glicoladas, e nas saturadas com $\mathrm{K}^{+}$, submetidas a 25,350 e $550^{\circ} \mathrm{C}$.

- silte e areia: difratogramas de raios-X (Dorronsoro, 1988; Taboada et al., 1990). Amostras deferrificadas, isentas de matéria orgânica e finamente moídas 
foram espalhadas sobre a superfície aderente de uma fita dupla face previamente colada sobre lamínula de vidro.

\subsubsection{4 pH de abrasão}

O método sugerido por Ferrari \& Magaldi (1983) prevê a utilização da fração tamanho 0,125-0,250 mm, que corresponde à areia fina (USDA, 1975). Entretanto, devido a dificuldades em relação à obtenção de quantidades suficientes de amostra, optou-se pela adoção das partículas do solo que se incluem no intervalo 0,100 e $0,500 \mathrm{~mm}$, ou seja, areia fina + areia média, para a determinação do $\mathrm{pH}$ de abrasão. Algumas modificações foram promovidas, especialmente quanto ao pré-tratamento das amostras. Substituiram-se os tratamentos com peróxido de hidrogênio e ebulição com ácido oxálico na presença de alumínio por solução de hipoclorito de sódio, ajustada a pH 9,5, e solução DCB (ditionito-citrato-bicarbonato) respectivamente para a eliminação da matéria orgânica e recobrimentos de óxidos e hidróxidos de ferro e alumínio. As amostras foram finamente moídas em moinho de porcelana por 30 minutos. Respeitou-se a relação 1:2,5 entre amostra moída : água destilada (a base de massa) e após seis minutos de contato o pH da suspensão foi lido. De posse dos valores de $\mathrm{pH}_{\mathrm{H} 2 \mathrm{O}}$ do solo e do $\mathrm{pH}$ de abrasão, calculou-se o índice $\mathrm{DpH}$ por diferença $\left(\mathrm{DpH}=\mathrm{pH}_{\mathrm{abrasão}}-\mathrm{pH}_{\text {solo }}\right)$.

\subsubsection{Determinação da $\mathrm{CTC}_{\mathrm{e}}$ e $\mathrm{CTA}_{\mathrm{e}}$ em $\mathrm{BaCl}_{2}$}

Estudos relacionados ao desenvolvimento agrícola em solos tropicais intemperizados mostram que o emprego de métodos tamponados para a determinação da CTC devem ser evitados. A CTC a pH 7,0 pode ser, em ordem de magnitude, maior do que aquela determinada ao $\mathrm{pH}$ de campo. Neste contexto, 
o uso da solução de $\mathrm{BaCl}_{2}$ não-tamponada permite que a CTC e a CTA sejam determinados ao pH do solo e sem alteração da força iônica da solução.

\subsubsection{Princípio}

Embora existam pequenas modificações nos métodos propostos para a determinação da CTC e CTA em $\mathrm{BaCl}_{2}$ (Rhoades, 1982; Camargo et al., 1986; Gillman \& Sumpter, 1986; Embrapa, 1997), eles derivam do método da troca compulsiva, preconizado por Gillman (1979) para solos ácidos da região tropical.

De acordo com o método original, o solo é saturado com $\mathrm{Ba}$ e posteriormente equilibrado com solução de cloreto de bário a uma concentração equivalente a força iônica da solução do solo. O Ba é deslocado pelo $\mathrm{Mg}$ após a adição de solução de $\mathrm{MgSO}_{4}$. A quantidade de $\mathrm{Mg}$ consumida do $\mathrm{MgSO}_{4}$ é medida, sendo equivalente ao adsorvido e, consequentemente, à CTC, como esquematizado a seguir (Rhoades, 1982), para $1 \mathrm{~kg}$ de solo (x, y e z são expressos em $\mathrm{mmol}_{\mathrm{c}}$ ):

$$
\begin{gathered}
\mathrm{x} \text { solo }-\mathrm{Ba}+\mathrm{yBaCl} \text { (entrante) }+\mathrm{zMgSO}_{4} \rightarrow \\
\text { x solo }-\mathrm{Mg}+\mathrm{yMgCl}{ }_{2}+(\mathrm{z}-\mathrm{x}-\mathrm{y}) \mathrm{MgSO}_{4}+(\mathrm{x}+\mathrm{y}) \mathrm{BaSO}_{4} \downarrow
\end{gathered}
$$

A adição de solução de $\mathrm{BaCl}_{2}$ promove a saturação do complexo de troca $(x)$ do solo com $\mathrm{Ba}$, que por sua vez retém uma quantidade $y$ de cloreto de bário, quando então entra em contato com a solução de $\mathrm{MgSO}_{4}(z)$, de concentração conhecida. $\mathrm{O} \mathrm{Ba}$ é deslocado pelo $\mathrm{Mg}$ que passa a dominar o complexo de carga. Parte do $\mathrm{Mg}$ que não é retida reage com $\mathrm{Cl}^{-}$, formando $\mathrm{MgCl}_{2}(y)$, enquanto que o $\mathrm{Ba}$, que antes estava retido no complexo de troca e no $\mathrm{BaCl}_{2}$ entrante, é precipitado na forma de $\mathrm{BaSO}_{4}(x+y)$. Do total de $\mathrm{Mg}$ adicionado, deve-se 
subtrair a quantidade reagida com $\mathrm{Cl}^{-}(y)$ e o restante de sulfato de magnésio que permaneceu no extrato $(z-x-y)$, de modo que:

$\mathrm{CTC}=\mathrm{Mg}$ perdido da solução reagente

$$
\begin{aligned}
& =\mathrm{z}-[\mathrm{y}+(\mathrm{z}-\mathrm{x}-\mathrm{y})] \\
= & \mathrm{x} \mathrm{mmol}_{\mathrm{c}} \mathrm{kg}^{-1}
\end{aligned}
$$

Soluções não tamponadas e pouco concentradas $\left(\mathrm{BaCl}_{2} 0,002 \mathrm{~mol} \mathrm{~L}^{-1} \mathrm{e}\right.$ $\left.\mathrm{MgSO}_{4} 0,0025 \mathrm{~mol} \mathrm{~L}^{-1}\right)$ são desejáveis devido sua força iônica ser próxima àquela encontrada nas soluções do solo, principalmente daqueles altamente intemperizados.

\subsubsection{Procedimentos}

Seguiu-se o método descrito em Camargo et al. (1986): pesaram-se $2 \mathrm{~g}$ de amostra (solo total, argila, silte, areia muito fina, areia fina, areia média e areia grossa + areia muito grossa) em tubo de centrífuga previamente tarado, aos quais adicionaram-se $20 \mathrm{~g}$ de solução $\mathrm{BaCl}_{2} 0,05 \mathrm{~mol} \mathrm{~L}{ }^{-1}$; o conjunto foi agitado por 2 horas em agitador mecânico, a $250 \mathrm{rpm}$. Após centrifugação, reteve-se 0 sobrenadante para determinação dos cátions trocáveis $\left(\mathrm{Ca}^{+2}, \mathrm{Mg}^{+2}, \mathrm{~K}^{+} \mathrm{e} \mathrm{Na}{ }^{+}\right)$. Promoveu-se a lavagem pela adição de $20 \mathrm{~g}$ de $\mathrm{BaCl}_{2}$,0,002 $\mathrm{mol} \mathrm{L}{ }^{-1}$ e agitação por 1 hora, centrifugando e descartando o sobrenadante. A etapa de lavagem se repetiu por duas vezes. Após a segunda lavagem com $\mathrm{BaCl}_{2}$ diluído, pesaram-se os tubos contendo solo úmido para a verificação da quantidade de solução de cloreto de bário retida. Adicionaram-se, então, $20 \mathrm{~g}$ de solução de $\mathrm{MgSO}_{4}$ 0,0025 mol L $\mathrm{L}^{-1}\left(0,005 \mathrm{~mol} \mathrm{~L}^{-1}\right.$ quando a CTC foi maior do que $100 \mathrm{mmol}_{\mathrm{c}} \mathrm{kg}^{-1}$, baseado em dados da análise de rotina) e agitou-se por 1 hora. Ajustou-se a condutividade elétrica para $0,3 \mathrm{mS} \mathrm{cm}^{-1}$ usando água destilada ou a solução de $\mathrm{MgSO}_{4} 0,0025$ mol $\mathrm{L}^{-1}$ e agitou-se por 1 noite, a $150 \mathrm{rpm}$. Após novo monitoramento da 
condutividade elétrica, e possíveis ajustes, pesaram-se os tubos para verificação da massa de $\mathrm{MgSO}_{4}$ 0,0025 mol L${ }^{-1}$ ou água. Após a centrifugação, recolheu-se o sobrenadante para determinação do $\mathrm{Mg}^{+2}\left(2 \mathrm{~mL}\right.$ do extrato $+20 \mathrm{~mL}$ de $\mathrm{La}_{3} \mathrm{O}_{2}$ $0,1 \%$ em La) por espectrometria de absorção atômica e do $\mathrm{Cl}^{-}(10 \mathrm{~mL}$ do extrato $+0,2 \mathrm{~mL}$ de $\mathrm{NaNO}_{3} 5 \mathrm{~mol} \mathrm{~L}^{-1}$ ) por determinação potenciométrica. Optou-se pela adição das soluções com pipeta automática e ajuste da massa com micro-pipeta, permitindo que os resultados fossem expressos por unidade de massa.

A CTC e a CTA foram estimados com base nos seguintes cálculos:

.$C T C$

Se $\mathrm{Mg}^{+2}$ foi adicionado para ajuste da condutividade da solução:

$$
\mathrm{CTC}\left(\mathrm{mmol}_{\mathrm{c}} \mathrm{kg}^{-1}\right)=500\left(0,01 \mathrm{~V}_{2}-\mathrm{C}_{1} \mathrm{~V}_{3}\right)
$$

Se água foi adicionada para ajuste da condutividade da solução:

$$
\mathrm{CTC}\left(\mathrm{mmol}_{\mathrm{c}} \mathrm{kg}^{-1}\right)=500\left(0,1-\mathrm{C}_{1} \mathrm{~V}_{3}\right)
$$

. CTA

$$
\operatorname{CTA}\left(\mathrm{mmol}_{\mathrm{c}} \mathrm{kg}^{-1}\right)=(1,02 / 35,45) \times\left[\mathrm{Cl}^{-}\right] \times \mathrm{V}_{3}
$$

Em que $\mathrm{V}_{1}=\mathrm{mL}$ de $\mathrm{BaCl}_{2}$ entrante; $\mathrm{V}_{2}=\mathrm{mL}$ de $\mathrm{MgSO}_{4}$ adicionado; $\mathrm{V}_{3}=$ $\mathrm{mL}$ final do sobrenadante $\left(10 \mathrm{~mL}+\right.$ correção do $\mathrm{MgSO}_{4}$ ou água adicionada + $\left.\mathrm{V}_{1}\right) ; \mathrm{C}_{1}=$ concentração final (meq $\mathrm{mL}^{-1}$ ) de $\mathrm{Mg}^{+2}$ no sobrenadante; $\mathrm{C}_{2}=$ concentração final (meq $\mathrm{mL}^{-1}$ ) de $\mathrm{Cl}^{-}$na solução de $\mathrm{BaCl}_{2} 0,002 \mathrm{~mol} \mathrm{~L}^{-1} ; \mathrm{C}_{3}=$ concentração final (meq $\mathrm{mL}^{-1}$ ) de $\mathrm{Cl}^{-}$no sobrenadante 


\subsection{Fração cascalhenta}

O material constituinte da matriz do solo aderido aos cascalhos foi eliminado por tratamento ultrassônico em água deionizada por 20 minutos (Weaver et al, 1992). Este tratamento substituiu o proposto pela Embrapa (1997), que sugere a imersão dos cascalhos em cápsula de porcelana contendo $\mathrm{NaOH} 1$ mol $L^{-1}$, seguida da agitação com bastão várias vezes ao dia e manutenção do material por uma noite nesta solução. Procedeu-se a secagem do material em estufa a $60^{\circ} \mathrm{C}$ e a subdivisão dos cascalhos em duas classes: cascalho fino (2,0 a $10,0 \mathrm{~mm})$ e cascalho grosso $(10,0$ a $20,0 \mathrm{~mm})$.

\subsubsection{Quantificação}

Estimativas visuais da participação de fragmentos grosseiros no perfil do solo são razoavelmente precisas para materiais maiores do que $75 \mathrm{~mm}$, classificados como calhaus. Para partículas menores do que $20 \mathrm{~mm}$, estimativas visuais tornam-se extremamente dificeis e irreais quando se trata de cascalho fino. Neste caso, a precisão das estimativas é aumentada com o peneiramento e pesagem da amostra, procedimento não recomendado para fragmentos cuja dimensão varia entre $20-75 \mathrm{~mm}$, devido à precisão da estimativa depender de um volume muito grande de amostra (Alexander, 1982).

Enquanto Alexander (1982) afirmou que a coleta de 200-500 g de amostra produzia resultados suficientemente precisos para fragmentos variando de 2-20 $\mathrm{mm}$, Ugolini et al. (1996) sugeriram um método para o estudo dos fragmentos de rocha pela coleta de um volume conhecido de amostra no campo $(4 \mathrm{~L})$, secamento e peneiramento para a obtenção de frações grossas e seleção por tamanho e grau de intemperização, mediante critérios de cor, brilho das superfícies minerais, presença de estrias e rugosidade da superfície. Este volume conhecido de amostra 
é considerado representativo dos solos estudados. Propuseram quantificar os fragmentos por seu conteúdo em volume $(\mathrm{Rv}=$ volume ocupado pelos fragmentos de rocha / volume que ocupa a amostra total $)$ ou em peso $(\mathrm{Rm}=$ peso dos fragmentos de rocha / peso da amostra total).

Childs \& Flint (1990) sugeriram a seguinte expressão para a transformação do conteúdo de fragmentos de rocha em peso para volume:

$$
\mathrm{Rv}=\mathrm{Rp} . \text { Das } / \mathrm{Daf}
$$

Em que Rv é o conteúdo de fragmentos de rocha em volume (\%); Rp é o conteúdo de fragmentos de rocha em peso; Das é a densidade do solo; Daf é a densidade dos fragmentos.

Coletou-se um volume superior ao sugerido por Ugolini et al. (1996) visando a obtenção de quantidade suficiente de terra fina. Quantificaram-se as frações terra fina, cascalhos (fino e grosso) e calhaus presentes na amostra original pelo cálculo da porcentagem após a obtenção do peso total da amostra, empregando as seguintes expressões (Embrapa, 1997) :

$\%$ terra fina $=100-(\%$ calhaus $+\%$ cascalho $)$

$\%$ calhaus $=100$ (peso calhaus $/$ peso amostra)

$\%$ cascalho $=100[$ (peso calhaus + peso cascalho $)-$ peso calhaus $] /$ peso total da amostra

\subsubsection{Análises químicas}

- pH em água: leitura do $\mathrm{pH}$ da suspensão (relação 1:1 cascalho:água destilada, a base de massa) após o equilíbrio alcançado em torno de 20 dias (Martín-García et al., 1999);

- $p H$ de abrasão: cascalhos intactos foram suavemente agitados por $16 \mathrm{~h}$ para a avaliação do $\mathrm{pH}$ de abrasão, respeitando a relação $1: 1$ cascalho:água destilada, a 
base de massa (20 g cascalho fino: $20 \mathrm{~g}$ de água; $40 \mathrm{~g}$ cascalho grosso: $40 \mathrm{~g}$ de água) não havendo necessidade de moagem conforme Ugolini et al. (1996);

- CTC efetiva $\left(C T C_{e}\right)$ : os cascalhos foram imersos em solução de $\mathrm{BaCl}_{2} 0,2 \mathrm{~mol} \mathrm{~L}$ 1 (relação 1:10 sólido:líquido, a base de massa) em frascos de polietileno e suavemente agitados. No oitavo dia, período em que ocorre o equilíbrio (Ugolini et al., 1996), recolheu-se uma alíquota para posterior determinação de $\mathrm{Ca}$ e $\mathrm{Mg}$ por absorção atômica, e K e Na por fotometria de emissão. Similar procedimento para a determinação da acidez trocável $(\mathrm{Al}+\mathrm{H})$ pela imersão dos fragmentos de rocha em solução extratora $\mathrm{KCl} 0,4 \mathrm{~mol} \mathrm{~L}^{-1}$ e titulação com $\mathrm{NaOH} 0,05 \mathrm{~mol} \mathrm{~L}^{-1}$ na presença de fenolftaleína.

\subsubsection{Análise mineralógica qualitativa}

O tratamento foi análogo àquele aplicado para silte e areia; os cascalhos foram primeiramente fragmentados em cilindro de aço com haste $\mathrm{e}$ posteriormente moídos em moinho de porcelana. O material fino foi espalhado até a cobertura total da superfície aderente da fita dupla face, colada sobre lamínula de vidro.

\subsection{Análise Estatística}

A partir dos resultados obtidos para a caracterização das amostras de terra fina e cascalhos, foram elaboradas correlações para a seleção das variáveis mais significativas para o estudo e análise de regressão múltipla, de modo a verificar quais os atributos que mais se correlacionaram com a CTC, CTA e pH de abrasão dos solos e das frações estudadas. 


\section{RESULTADOS E DISCUSSÃO}

\subsection{Análises químicas}

\subsubsection{Análises químicas de rotina}

Observou-se grande heterogeneidade na fertilidade dos solos (Tabela 5). Isso era esperado em função dos diferentes materiais de origem. Todos os LATOSSOLOS, por serem muito intemperizados, apresentaram $\mathrm{CTCs}_{\mathrm{e}}$ inferiores

a $15 \mathrm{mmol}_{\mathrm{c}} \mathrm{kg}^{-1}$ de argila, atendendo, simultaneamente, aos critérios para seu enquadramento dentro da ordem e a uma das exigências para apresentar caráter ácrico (Embrapa, 1999). De maneira geral, os teores de $\mathrm{K}$, Ca e $\mathrm{Mg}$ decresceram em subsuperfície. Com exceção do horizonte B do LAw-2 e do horizonte A do LVwf, que apresentaram teores médio e alto, respectivamente, de acordo com critérios estabelecidos por Raij et al. (1996), talvez por serem intensivamente cultivados, os LATOSSOLOS mostraram-se pobres em potássio. Notou-se deficiência de $\mathrm{Ca}$ e $\mathrm{Mg}$, com exceção do LVwf, que apresentou diferença entre os teores em superfície (alto) e subsuperfície (médio), provavelmente pela prática regular de calagem. Os LATOSSOLOS ácricos do município de Uberlândia suportam vegetação nativa de Cerrado; nestes solos observou-se estreita relação entre os baixos valores de $\mathrm{pH}$ em $\mathrm{CaCl}_{2}$ e a baixíssima saturação por bases. Os níveis de matéria orgânica foram médios desde a superfície até ao primeiro metro. Este atributo certamente ainda não sofreu as transformações desencadeadas por sistemas de manejo agrícola e permanece em equilíbrio no sistema. 


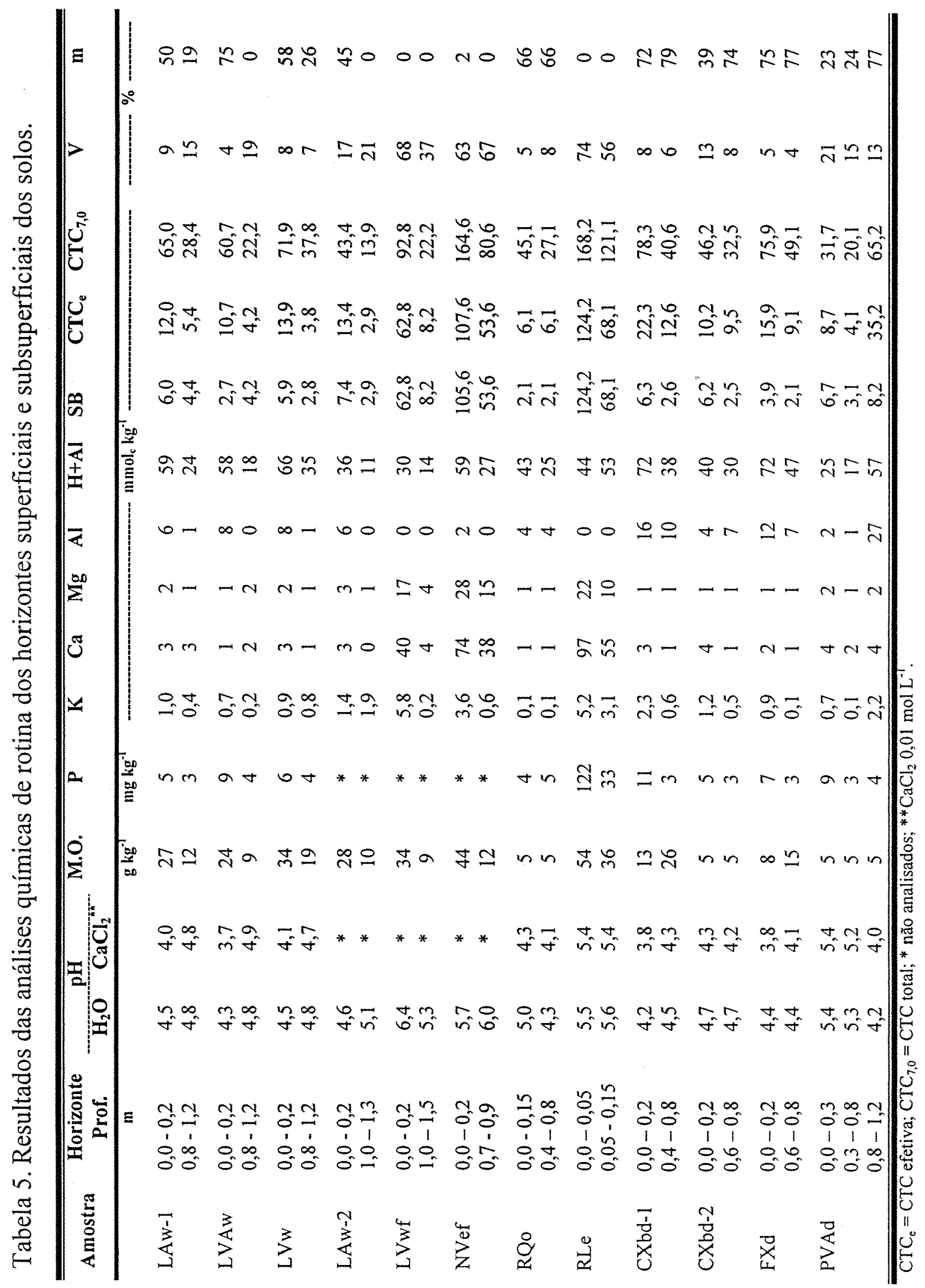


O NVef, mesmo sendo muito intemperizado, possui atributos químicos satisfatórios em termos de fertilidade, não somente pelos níveis de bases trocáveis serem adequados dentro das condições do Estado de São Paulo (Raij et al., 1996), mas também por estes elementos estarem predominando no complexo de troca, garantindo a propriedade eutrófica para ambos os horizontes. Níveis baixos de matéria orgânica, bem abaixo de $15 \mathrm{~g} \mathrm{~kg}^{-1}$, teor apontado por Raij et al. (1996) para solos arenosos, certamente não são capazes de garantir fertilidade adequada ao RQo e ao PVAd. A macroporosidade excessiva destes solos, conseqüência da textura arenosa, acelera o processo de oxidação da matéria orgânica (Stevenson, 1994). Com isso, a capacidade de troca de cátions destes solos torna-se pouco operante, mesmo porque seus componentes minerais, que tiveram sua origem do arenito, não exibem esta propriedade com grande expressão.

O teor de matéria orgânica no PVAd é baixo e constante na camada 0-1,2 m, mas a quantidade de bases trocáveis é heterogênea, com aumento no horizonte $\mathrm{Bt}$, provavelmente por se tratar de um horizonte iluvial em que a quantidade de argila é maior. O horizonte $\mathrm{E}(0,3-0,8 \mathrm{~m})$ é muito pobre em bases, a exemplo dos horizontes $\mathrm{A}$ e $\mathrm{C}$ do RQo, e por isso são limitantes ao cultivo, principalmente de culturas anuais que exploram as camadas mais superficiais.

Os solos pedregosos, CXbd-1, CXbd-2 e FXd, apresentaram pH em água menor que 5, talvez por não serem cultivados em função de suas limitações físicas. Os CAMBISSOLOS apresentam baixos pHs em função do material de origem, que por serem de natureza ácida, não suprem estes solos de bases trocáveis, mesmo estando em estádio menos avançado de intemperização. Especialmente no CXbd-2, os teores de matéria orgânica de seus horizontes são extremamente baixos, similares aos do RQo e do PVAd, podendo, então, estar associados com a textura. Na camada $0-0,8 \mathrm{~m}$, os teores de $\mathrm{Ca}, \mathrm{Mg}$ e $\mathrm{K}$ são baixos (Raij et al., 1996). 
Analogamente, o FXd é um solo com baixo potencial nutricional e de uso restrito, em virtude de suas limitações de ordem física, além de problemas de toxidez por alumínio, elemento que predomina no complexo de troca. O RLe destaca-se entre os solos cascalhentos pelo seu alto potencial nutricional apesar de restrições ao seu uso agrícola, principalmente às operações mecanizadas. Os teores de $\mathrm{Ca}, \mathrm{Mg}$ e $\mathrm{K}$, bem como de $\mathrm{P}$ e matéria orgânica, estão bem acima daqueles considerados como altos por Raij et al. (1996).

\subsubsection{Análises químicas complementares}

A relação molecular entre os teores de $\mathrm{SiO}_{2}, \mathrm{Al}_{2} \mathrm{O}_{3}$ e $\mathrm{Fe}_{2} \mathrm{O}_{3}$ (Tabela 6), resultantes do ataque sulfúrico, dá origem aos índices $\mathrm{ki} \mathrm{e} \mathrm{kr} \mathrm{que,} \mathrm{de} \mathrm{acordo} \mathrm{com}$ Resende \& Santana (1988), auxiliam no enquadramento dos solos em diferentes classes: caulinítico não sesquioxídico : $\mathrm{ki}>0,75$ e kr $>0,75$; gibsítico sesquioxídico : $\mathrm{ki} \leq 0,75$ e $\mathrm{kr} \leq 0,75$; caulinítico sesquioxídico : $\mathrm{ki}>0,75$ e $\mathrm{kr} \leq$ 0,75 . Pela composição qualitativa que discrimina cada classe, esta classificação é mais apropriada para solos muito intemperizados, como propuseram Resende \& Santana (1988). Sendo assim, a análise dos resultados dos horizontes diagnósticos de subsuperfície permite classificar os LATOSSOLOS como cauliníticos sesquioxídicos, exceção feita ao LVwf, classificado como gibsítico sesquioxídico. O NVef, por apresentar maiores índices ki e kr, foi classificado como caulinítico não sesquioxídico.

O critério empregado pela Embrapa (1999) é menos abrangente e considera apenas o índice kr, embora derivado de Resende \& Santana (1988). Os solos são agrupados em: caulinítico $: \mathrm{kr}>0,75$ ou oxídico $: \mathrm{kr} \leq 0,75$. Desta forma, todos os demais solos são considerados cauliníticos, exceto o FXd que, a exemplo dos solos anteriormente classificados, é oxídico. 


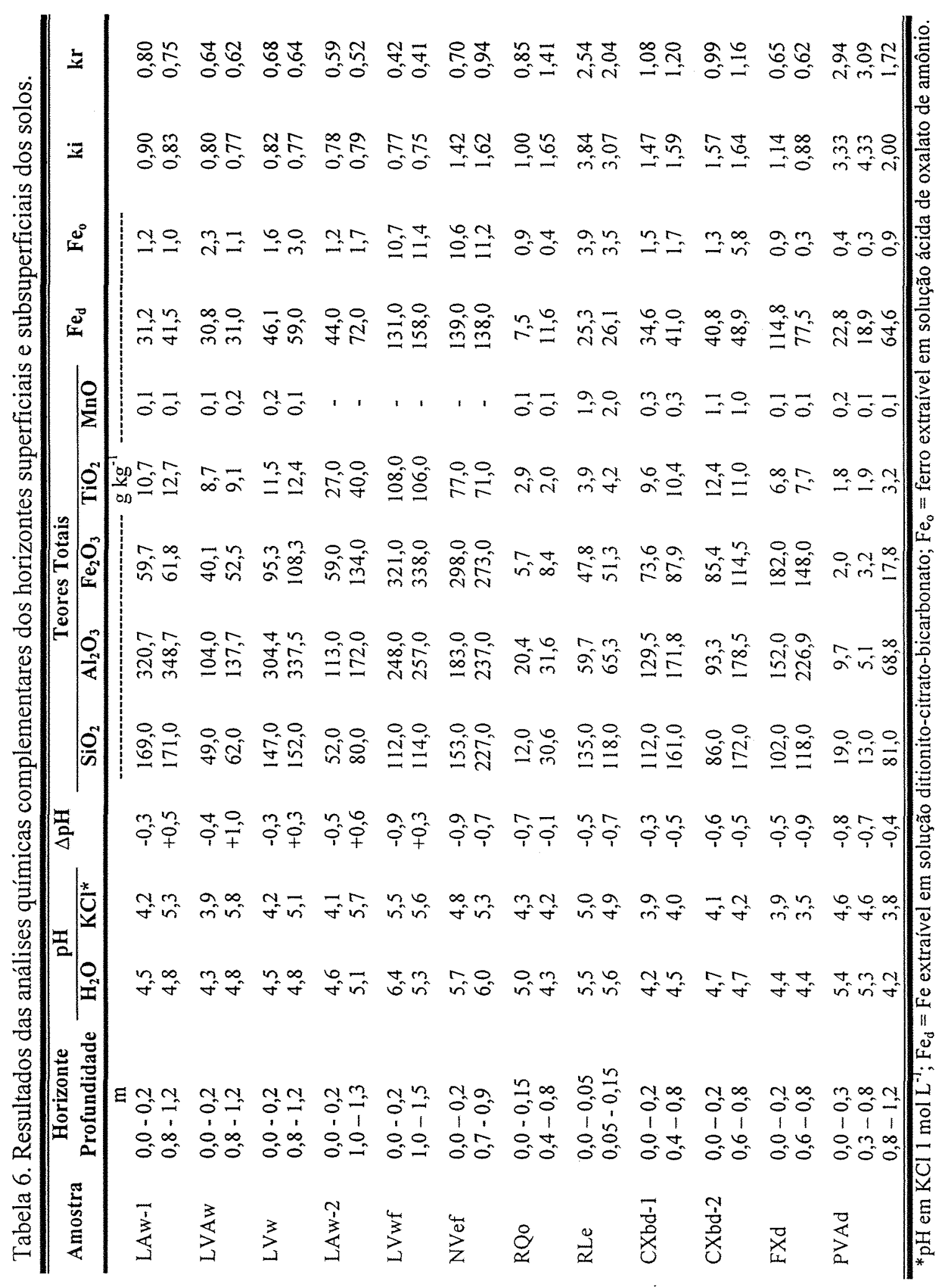


Os indices ki e kr não constituem referencial consistente quanto à composição qualitativa, embora mostrem a proporção global dos principais elementos que constituem os minerais secundários da terra fina (Oliveira et al., 1992).

Os elementos $\mathrm{Fe}, \mathrm{Al}, \mathrm{Mn}$ e Ti são gradativamente liberados dos minerais primários, assim como o $\mathrm{Si}$ e as bases $\mathrm{Ca}, \mathrm{Mg}, \mathrm{K}$ e $\mathrm{Na}$. Os primeiros são pouco solúveis e tendem a formar óxidos e hidróxidos, enquanto que processos contínuos de perda envolvem os demais. Infere-se, portanto, que o material de origem é decisivo na concentração destes elementos. Os elevados teores de Fe e Al totais no NVef, LVwf e, em menor expressão, no LAw-2, eram esperados e corroboram Alleoni (1992) e Alleoni \& Camargo (1994ab). A menor presença de sílica no basalto é compensada pelos teores de ferro e alumínio que permanecem no solo sob formas estáveis. Resultados do FXd surpreendem, pois não houve associação de seus teores totais de $\mathrm{Fe}$ e $\mathrm{Al}$ com o material parental. Pode haver óxidos de ferro na composição do siltito quando eles atuam como material cimentante, mas em baixas concentrações, como as determinadas no RLe. Uma possível explicação é a posição do FXd no relevo. Apesar de sua baixa solubilidade na forma de óxidos, o $\mathrm{Fe}$ pode reduzir-se e solubilizar-se, acompanhando o fluxo hídrico. Assim, cotas mais baixas do relevo tendem a acumular Fe com formação de bancadas lateríticas, plintita ou, após diversos ciclos de umedecimento/secamento, concreções ferruginosas (Daniels, 1982), como é o caso do FXd. Assim também se explicam os menores teores de $\mathrm{Fe}$ e $\mathrm{Al}$ no LAw-2. Sua posição normalmente coincide com cotas intermediárias do relevo e, neste caso específico, há condição de drenagem deficiente, que permite a redução e exportação do Fe declive abaixo (Oliveira \& Prado, 1991). Isso ainda responde pela matiz mais amarelada do que 4YR do LAw-2. Em condições de estagnação ou acúmulo temporário de água, a hematita pode se hidratar e formar goetita, que confere coloração mais amarelada aos solos. 
Os dois solos originados de sedimentos inconsolidados apresentaram teores discrepantes de ferro total. O LAw-1 está posicionado em uma área de subsidência, onde o acúmulo de água é constante. Dessa forma, o Fe encontra condições para redução e conseqüente solubilização, o que explica seu menor teor em relação ao LVw. Os teores de óxidos de alumínio total são altos e podem estar vinculados à matriz muito argilosa composta por aluminossilicatos.

Os óxidos de ferro que atuam como agentes cimentantes do arenito do grupo Bauru podem ter contribuído para o maior teor de Fe total do LVAw, quando comparado aos do RQo e PVAd, que por sua vez são oriundos de arenito cimentado por argila.

Para os CAMBISSOLOS, eram esperados índices de intemperismo mais elevados, principalmente pela elevada quantidade de material grosseiro, que sofreu muito intemperismo físico mas, aparentemente, com pouca alteração química e mineralógica. No entanto, os índices ki destes solos foram menores que 2,0, que denotam a presença de caulinita. Somente o RLe dá indicativos da presença de argilominerais de grade 2:1.

\subsection{Análises físicas}

Em virtude das diferenças texturais encontradas nas 25 amostras (Tabela 7), houve dificuldade na obtenção de volumes suficientes de cada fração granulométrica. A relação empregada entre solo:solução dispersante (hexametafosfato de sódio + hidróxido de sódio) foi de 1:5, ou seja, $50 \mathrm{~g}$ de solo para $250 \mathrm{~mL}$ de solução. Para solos de textura muito arenosa, como RQo e PVAd, e para solos de textura média, LVAw e CXbd-2, foram necessárias seis a sete dispersões. utilizaram-se, portanto, em torno de 300 a $400 \mathrm{~g}$ de amostra para a obtenção das frações argila e silte. A situação foi inversa para solos de textura argilosa a muito argilosa, em que foi necessário a dispersão de 400 a $500 \mathrm{~g}$ de 


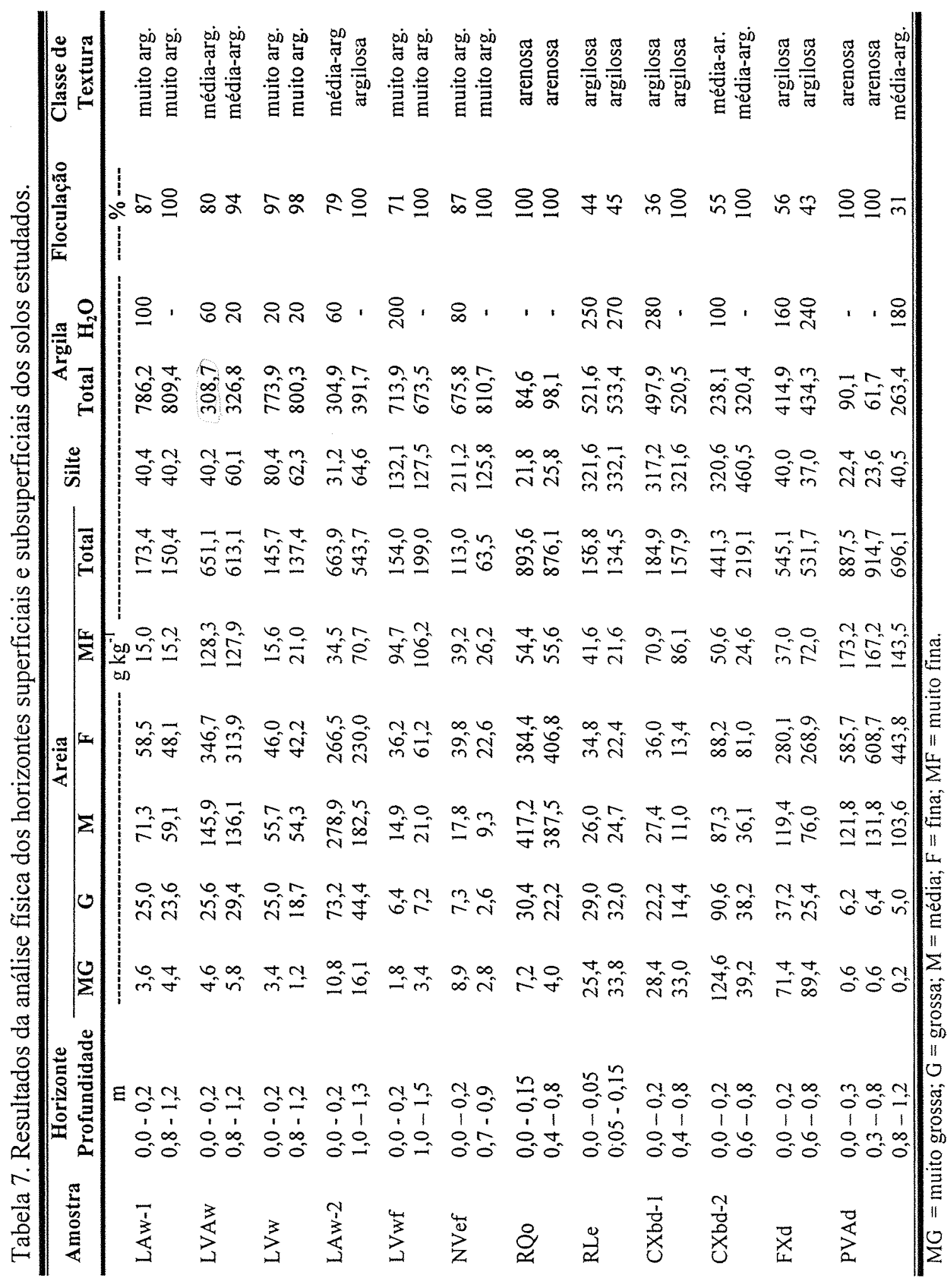


solo para a obtenção de um volume de areia que permitisse a determinação do $\mathrm{pH}$ de abrasão e da capacidade de troca iônica.

A homogeneidade na distribuição das partículas ao longo dos perfis dos LATOSSOLOS foi constante. Partículas de areia de dimensões entre fina e média dominam a textura do RQo e do PVAd, sendo que para este último, o gradiente textural entre os horizontes $\mathrm{E}$ e $\mathrm{Bt}$ foi evidente, pois o conteúdo de argila aumentou quatro vezes, permitindo classificá-lo como abrúptico no quarto nível categórico (Embrapa, 1999). O silte predomina nos solos cascalhentos (RLe, CXbd-1 e CXbd-2), exceto no FXd, mas todos apresentam razoável contribuição das partículas mais grossas de areia, quando comparados aos demais solos.

A dispersão e floculação de colóides são importantes processos que ocorrem como conseqüência das propriedades elétricas e relacionam-se com a superfície específica e com as cargas elétricas dos colóides (Bohn et al., 1979), apesar de não terem sido obtidas correlações com os principais atributos que governam a atividade elétrica em solos intemperizados, como o pH e o conteúdo de matéria orgânica. Há relatos de maior dispersão de argila em superfície de solos com carga elétrica variável, associada aos conteúdos de matéria orgânica, que constitui uma das principais fontes de cargas negativas do solo (Raij \& Peech, 1972). Além disso, há evidências de dispersão da caulinita, devido à ação de ânions orgânicos produzidos pela decomposição da matéria orgânica (Oades, 1984).

\subsection{Análise mineralógica qualitativa}

\subsubsection{Argila}

Nas figuras 3 a 14 são apresentados os difratogramas de raios- $X$ da fração argila deferrificada dos horizontes subsuperficiais dos solos, saturadas com $\mathrm{K} \mathrm{e}$ 


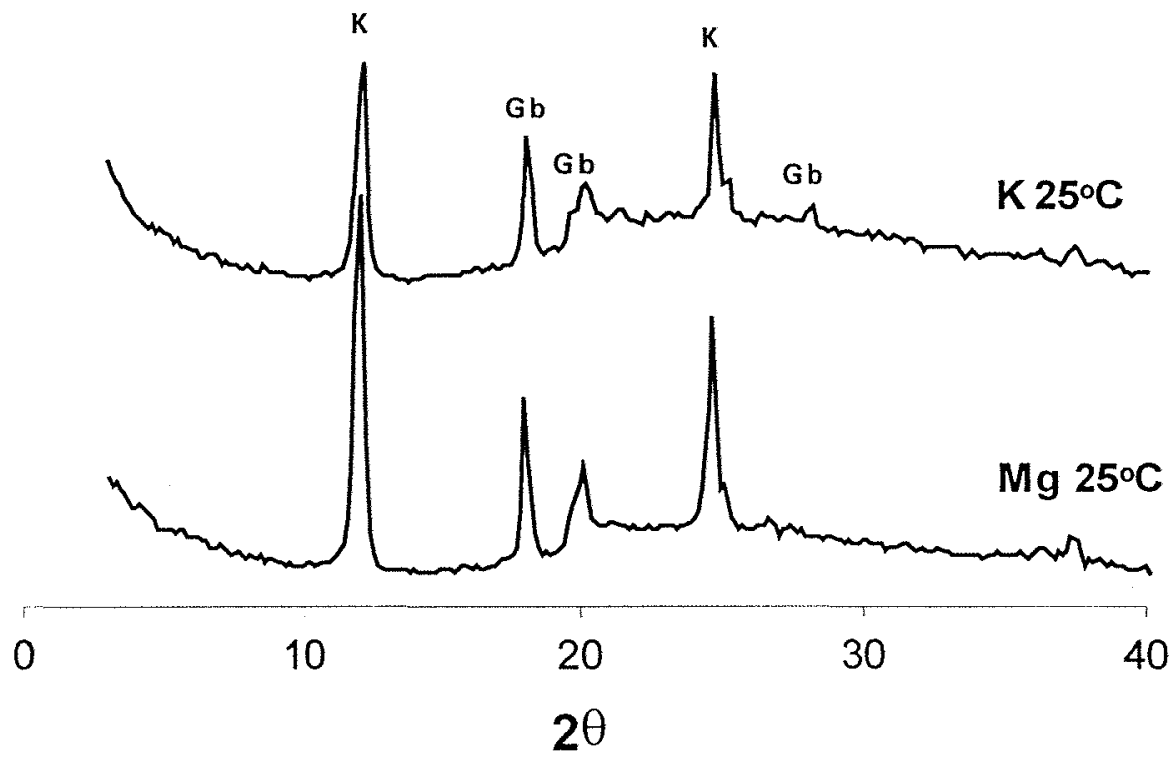

Figura 3 - Difratograma de raios-X da fração argila deferrificada do horizonte subsuperficial do LAw-1 ( $\mathrm{K}=$ caulinita; $\mathrm{Gb}=$ gibbsita).
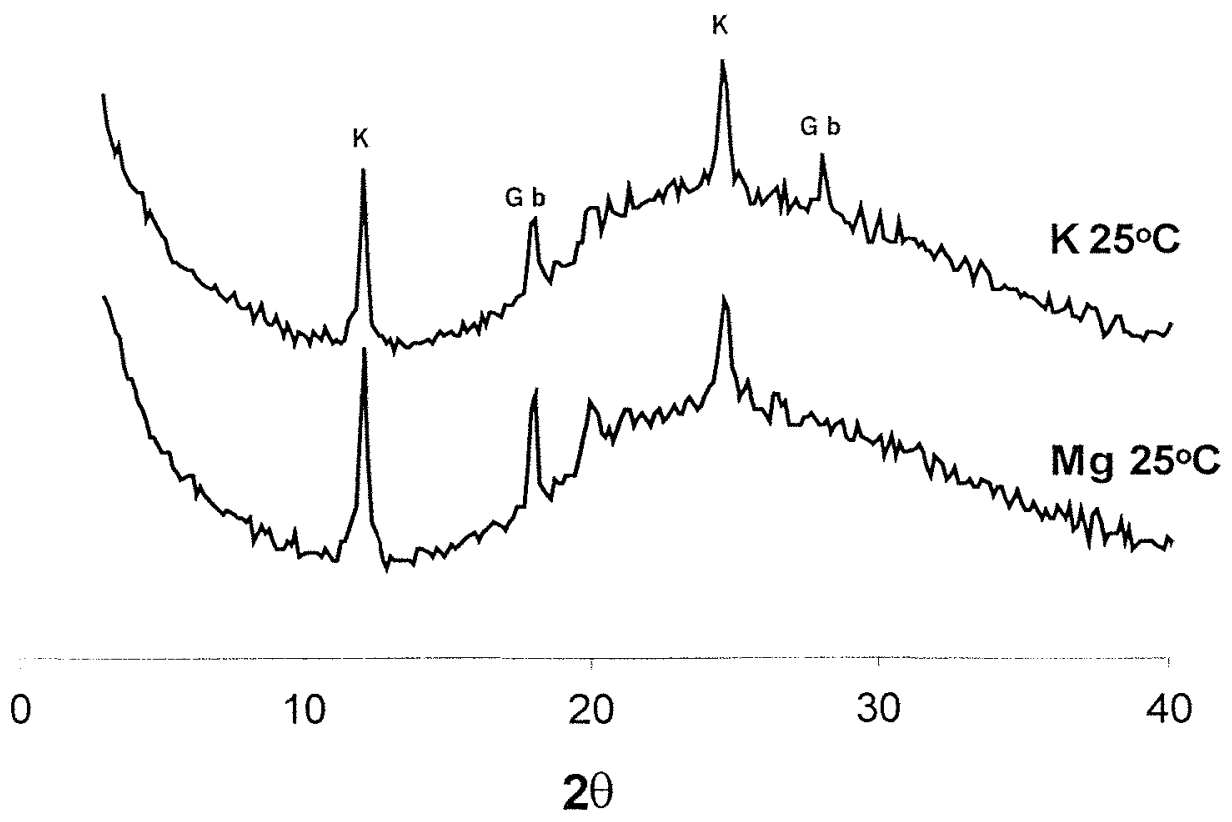

Figura 4 - Difratograma de raios-X da fração argila deferrificada do horizonte subsuperficial do LVAw ( $\mathrm{K}=$ caulinita; $\mathrm{Gb}=$ gibbsita). 


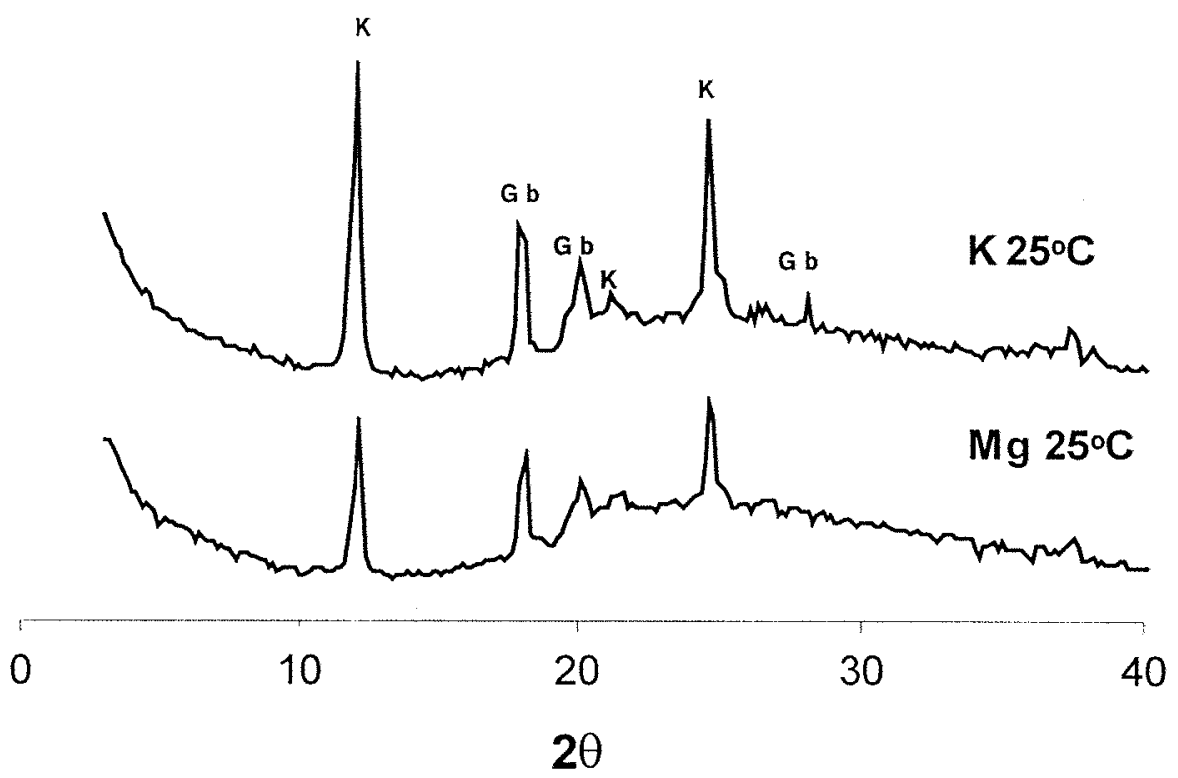

Figura 5 - Difratograma de raios-X da fração argila deferrificada do horizonte subsuperficial do LVw $(\mathrm{K}=$ caulinita; $\mathrm{Gb}=$ gibbsita $)$.

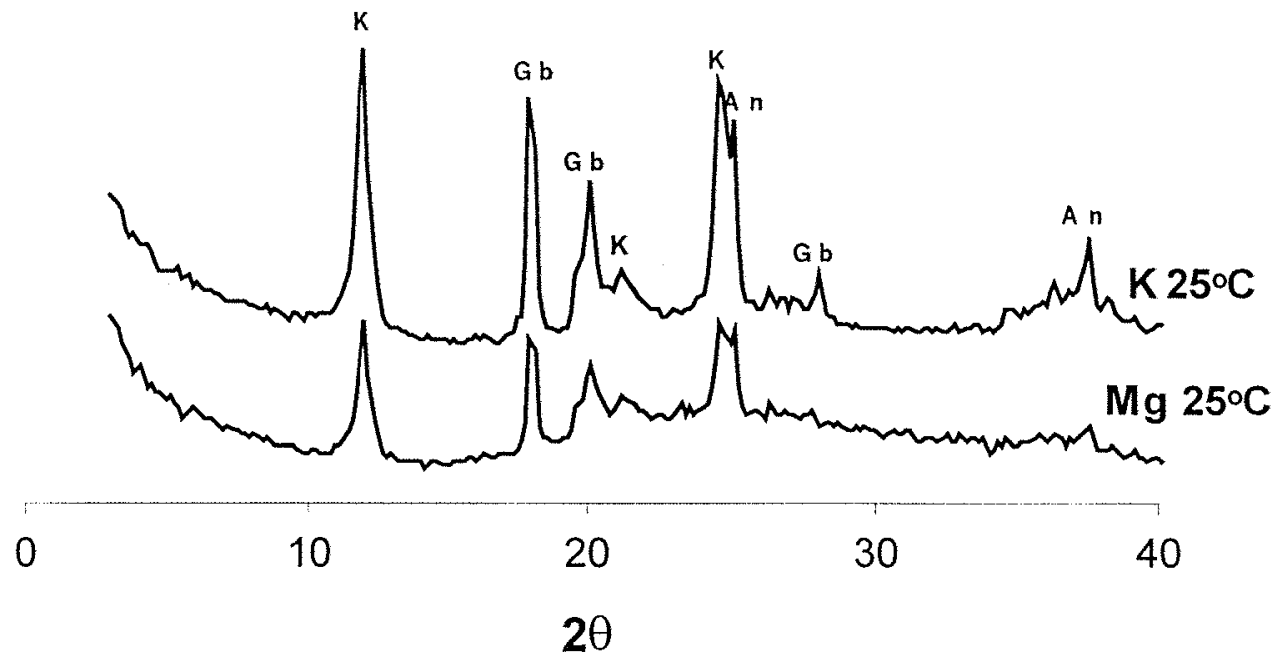

Figura 6 - Difratograma de raios-X da fração argila deferrificada do horizonte subsuperficial do LAw-2 ( $\mathrm{K}$ = caulinita; $\mathrm{Gb}=$ gibbsita; $\mathrm{An}=$ anatásio). 


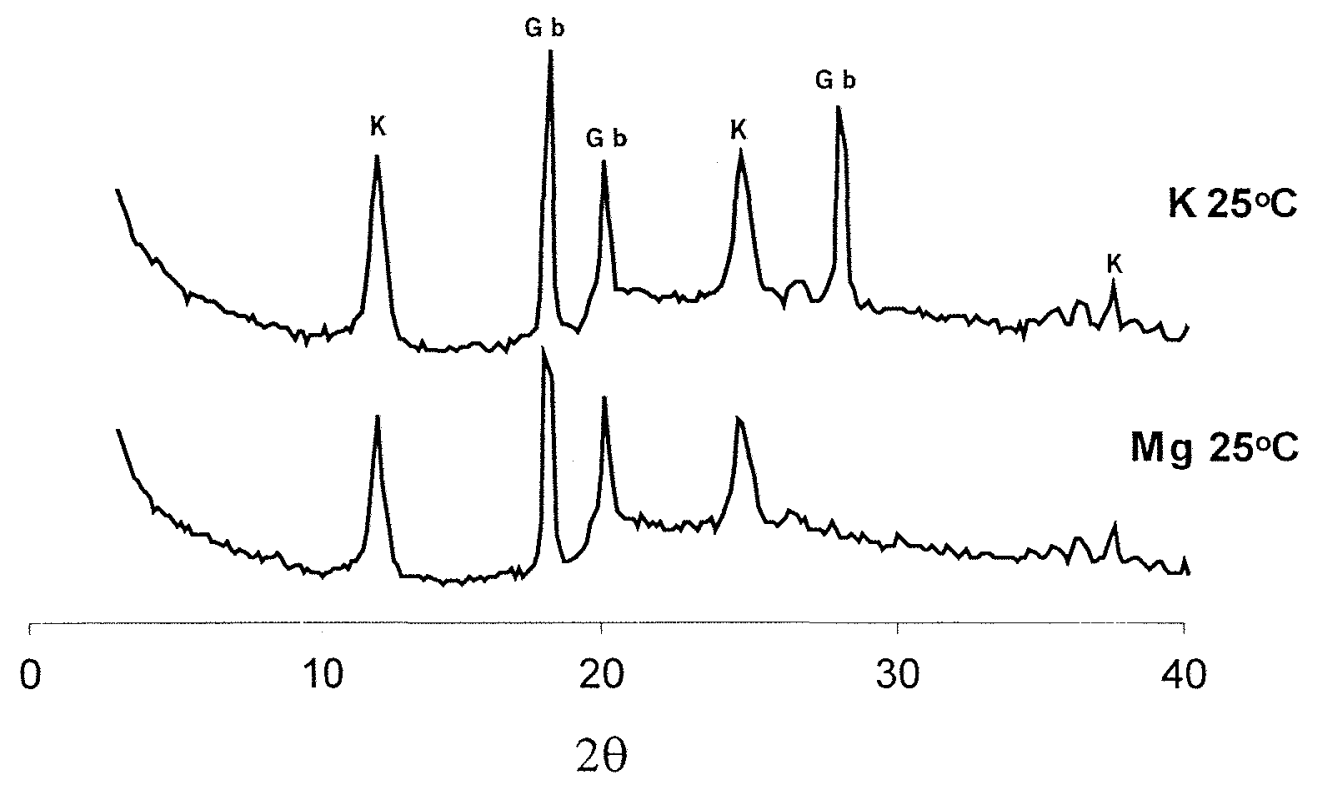

Figura 7 - Difratograma de raios-X da fração argila deferrificada do horizonte subsuperficial do $L V w f(K=$ caulinita; $G b=$ gibbsita).

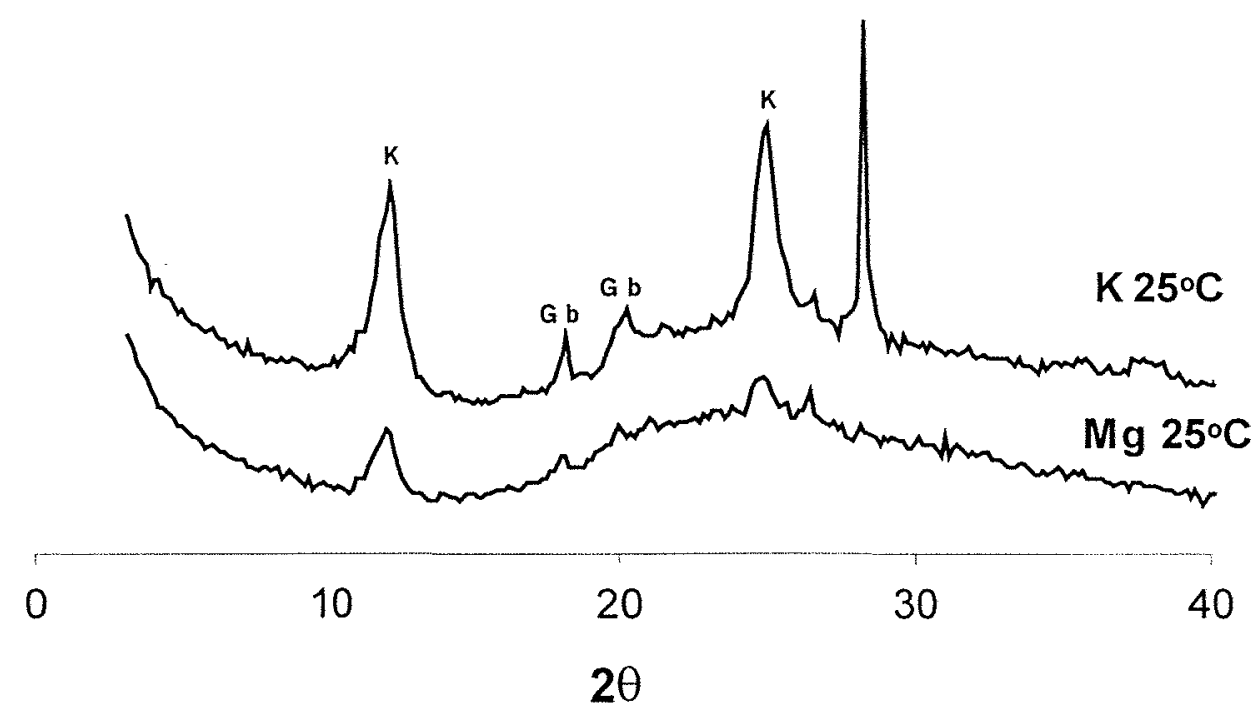

Figura 8 - Difratograma de raios-X da fração argila deferrificada do horizonte subsuperficial do NVef $(\mathrm{K}=$ caulinita; $\mathrm{Gb}=$ gibbsita). 


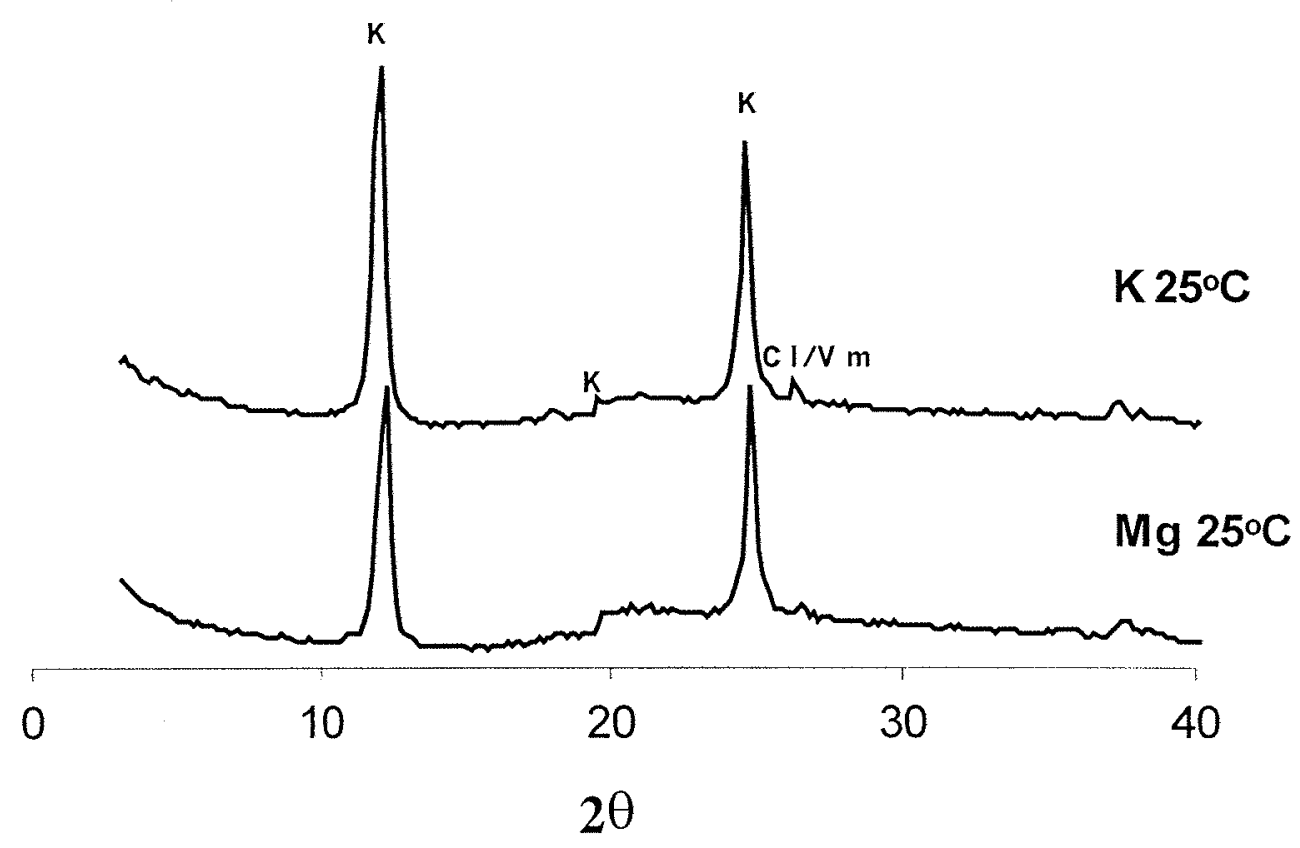

Figura 9 - Difratograma de raios-X da fração argila deferriticada do horizonte subsuperficial do $\mathrm{RQo}(\mathrm{K}=$ caulinita; $\mathrm{Cl} / \mathrm{Vm}=$ clorita-vermiculita).

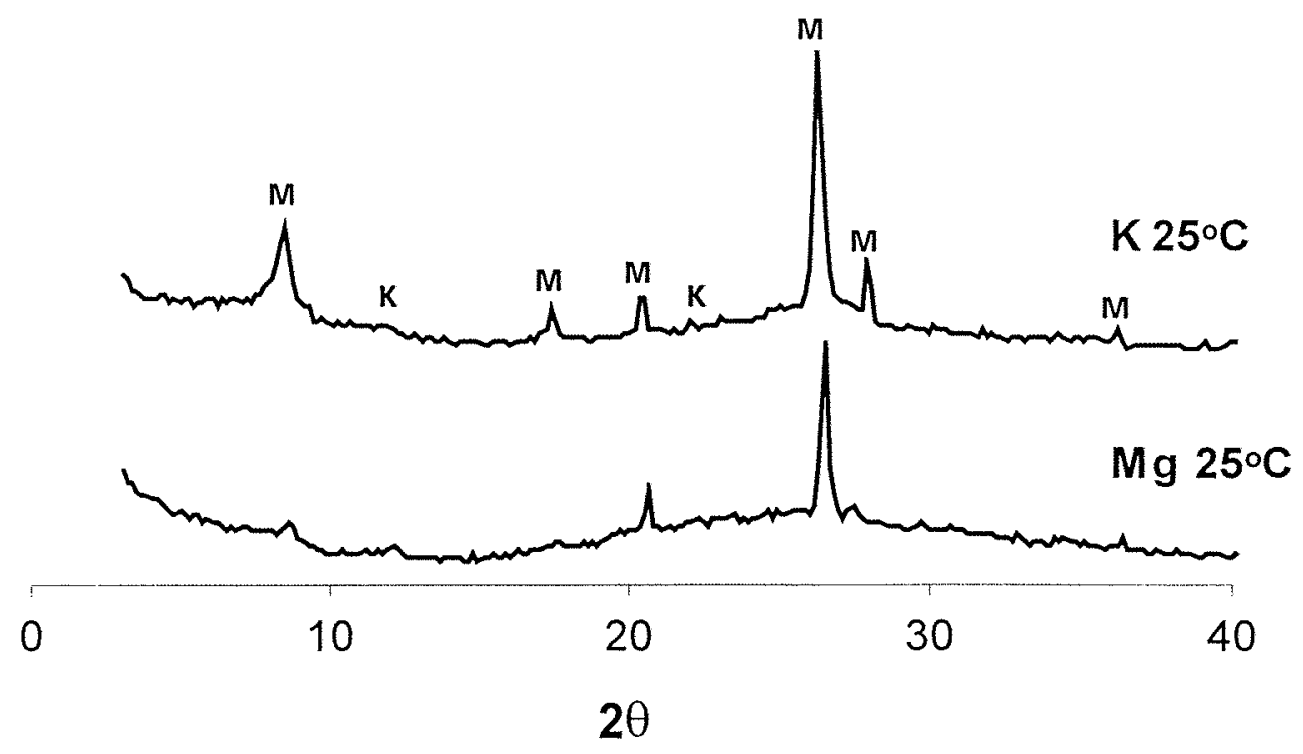

Figura 10 - Difratograma de raios-X da fração argila deferrificada do horizonte subsuperficial do $\mathrm{RLe}(\mathrm{K}=$ caulinita; $\mathrm{M}=$ ilita). 


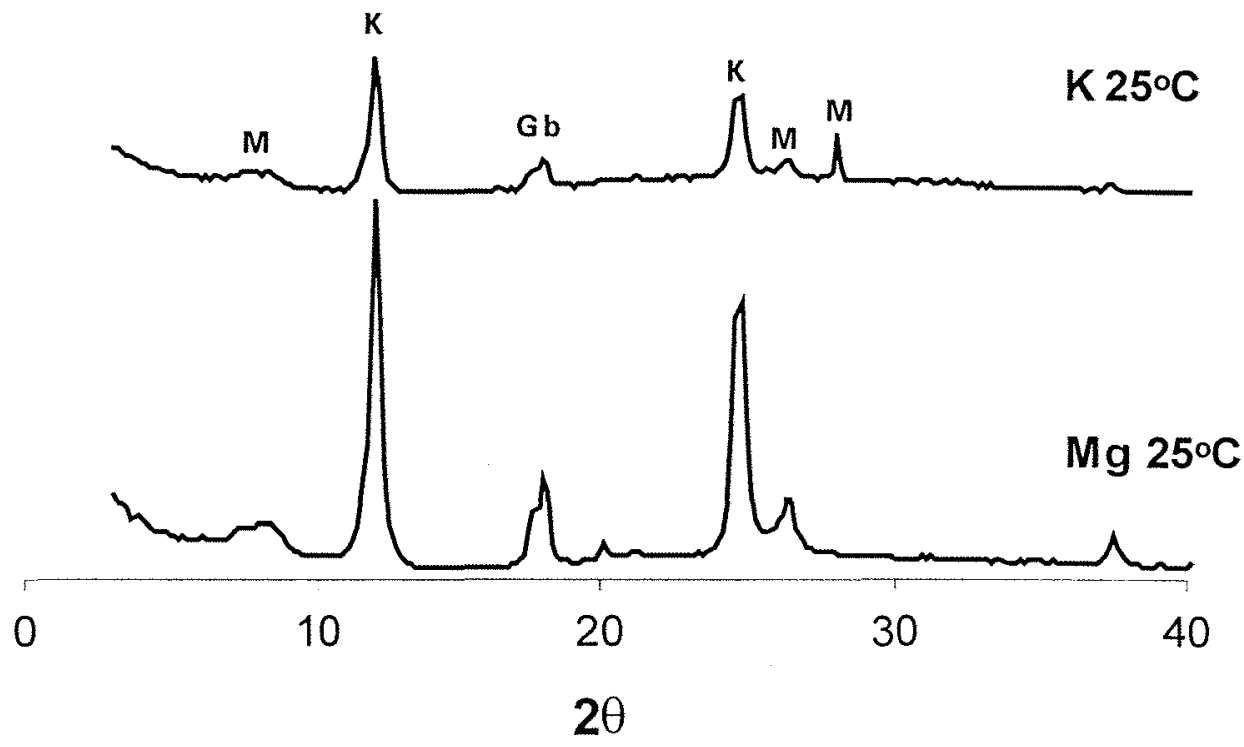

Figura 11 - Difratograma de raios-X da fração argila deferrificada do horizonte subsuperficial do CXbd-1 ( $\mathrm{K}=$ caulinita; $\mathrm{Gb}=$ gibbsita; $\mathrm{M}=$ ilita).

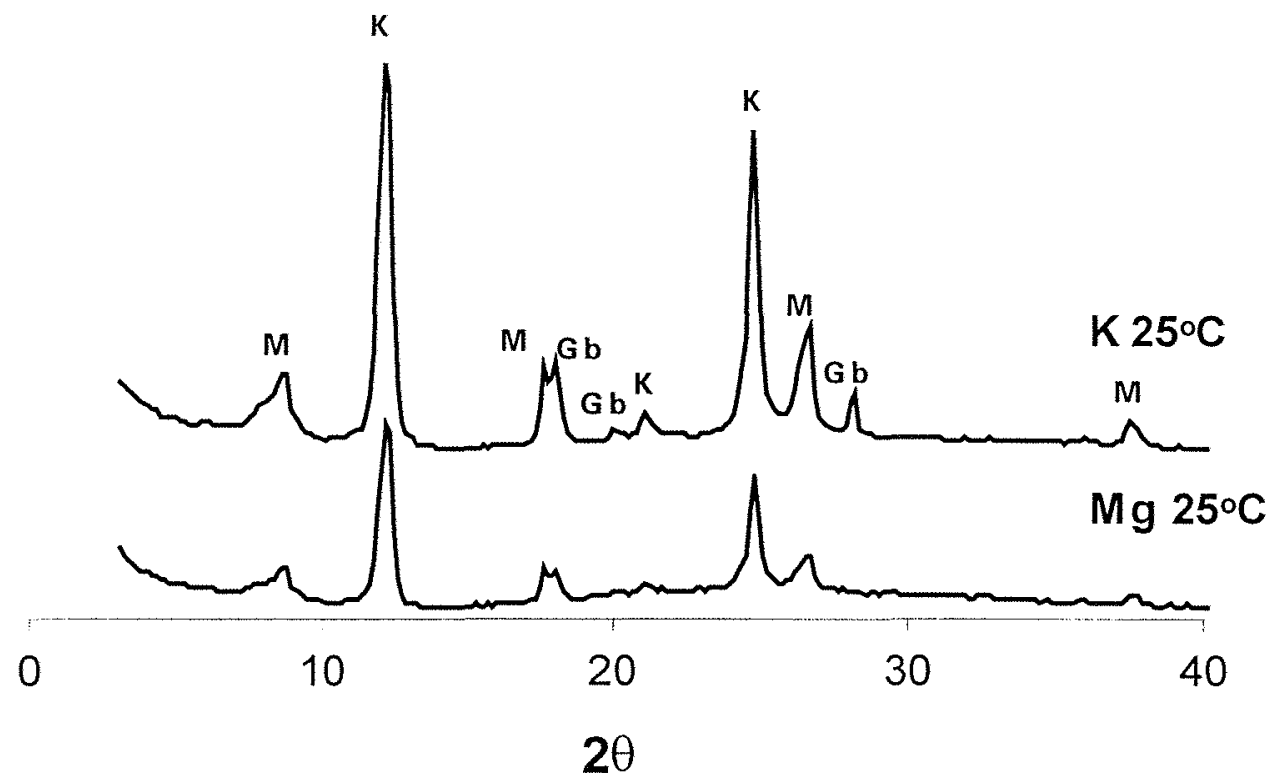

Figura 12 - Difratograma de raios-X da fração argila deferrificada do horizonte subsuperficial do $\mathrm{CXbd}-2$ ( $\mathrm{K}$ = caulinita; $\mathrm{Gb}=$ gibbsita; $\mathrm{M}=$ mica). 


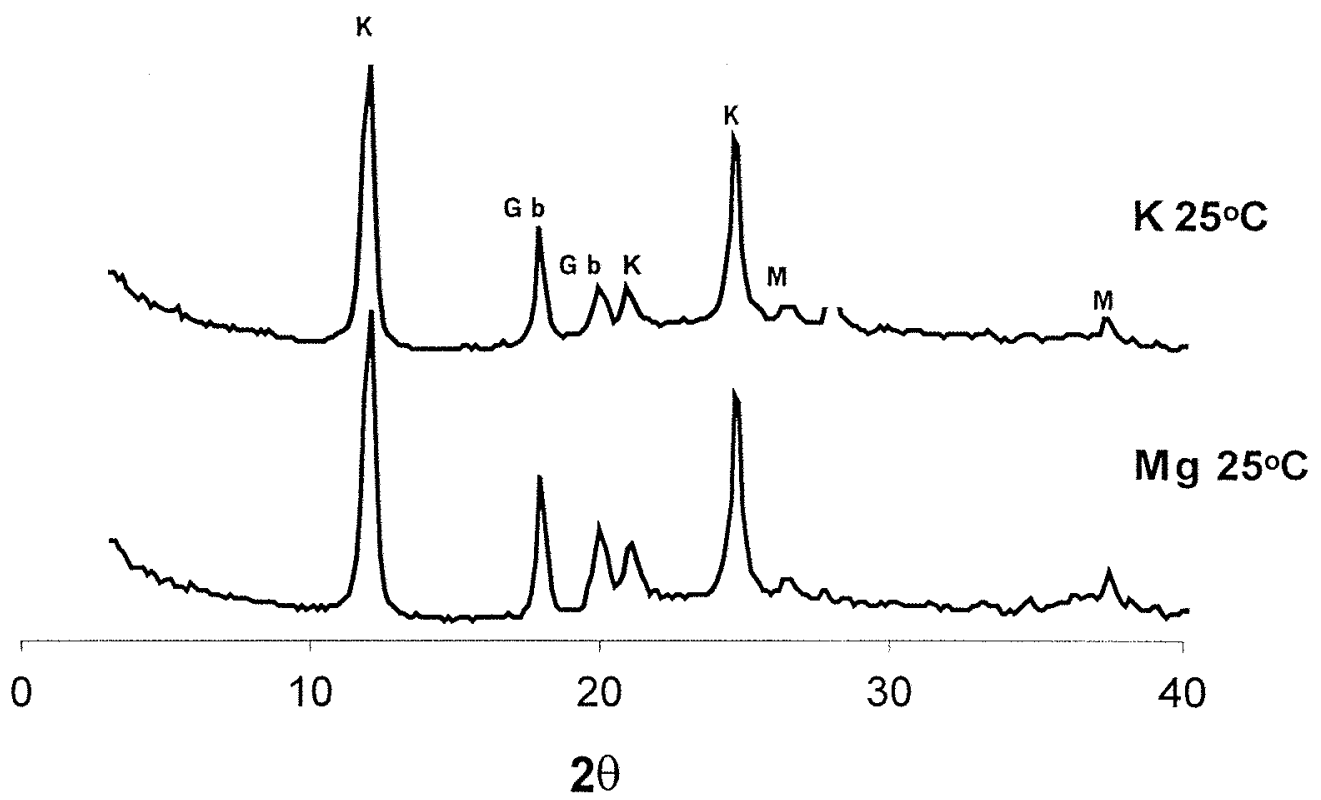

Figura 13 - Difratograma de raios-X da fração argila deferrificada do horizonte subsuperficial do FXd ( $\mathrm{K}=$ caulinita; $\mathrm{Gb}=$ gibbsita; $\mathrm{M}=$ mica).

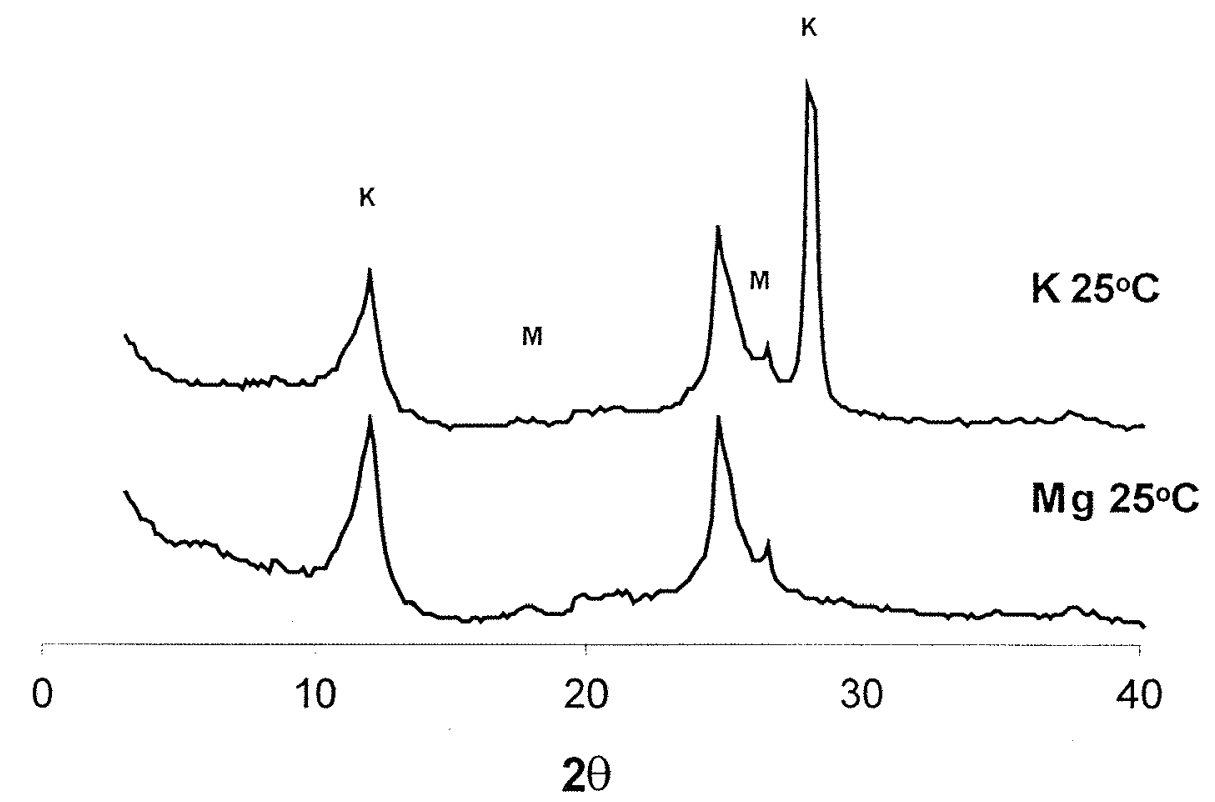

Figura 14 - Difratograma de raios-X da fração argila deferrificada do horizonte subsuperficial do PVAd ( $\mathrm{K}$ = caulinita; $\mathrm{M}=$ mica). 
$\mathrm{Mg}$ e analisadas em condições naturais (a $25^{\circ} \mathrm{C}$ ). Em todos os LATOSSOLOS e no NVef a caulinita e a gibbsita foram os minerais dominantes. Tal composição mineralógica está de acordo com solos muito intemperizados. O LAw-1 e o LAw2 apresentaram ainda picos de anatásio, óxido de titânio extremamente resistente ao intemperismo e aos tratamentos de deferrificação. O RQo apresentou, além da caulinita, picos de mineral interestratificado do tipo clorita/vermiculita.

A caulinita foi mineral comum entre os demais solos, mas não o dominante. O RLe apresentou mica e mica interestratificada para ilita como principais minerais. Mica, gibbsita e caulinita foram os minerais componentes da fração argila dos CAMBISSOLOS, sendo que o CXbd-2 apresentou também vermiculita. A mineralogia do FXd, a exemplo dos LATOSSOLOS, foi dominada por caulinita e gibbsita, com picos de mica. O PVAd apresentou argilas micáceas e cauliníticas.

\subsubsection{Areia e silte}

As análises mineralógicas das frações silte e areia dos solos podem ser vistas nas figuras 15 a 26 .

O predomínio de quartzo e feldspatos nas frações mais grossas do solo é amplamente citado pela literatura. Depois do quartzo, feldspatos são os minerais primários mais comuns no solo, presentes na fração areia e silte. Em oxissolos podem estar ausentes ou somente em quantidades traço (Huang, 1989). Entretanto, todos os LATOSSOLOS, especialmente os derivados de basalto, apresentaram feldspatos na constituição mineralógica do silte e da areia. Feldspatos potássicos são mais resistentes ao intemperismo do que os plagioclásios. A freqüência e ocorrência de diferentes plagioclásios no solo varia grandemente, primeiramente devido a grande estabilidade dos membros sódicos, como a albita e o oligoclásio, em relação aos cálcicos, como a anortita. 

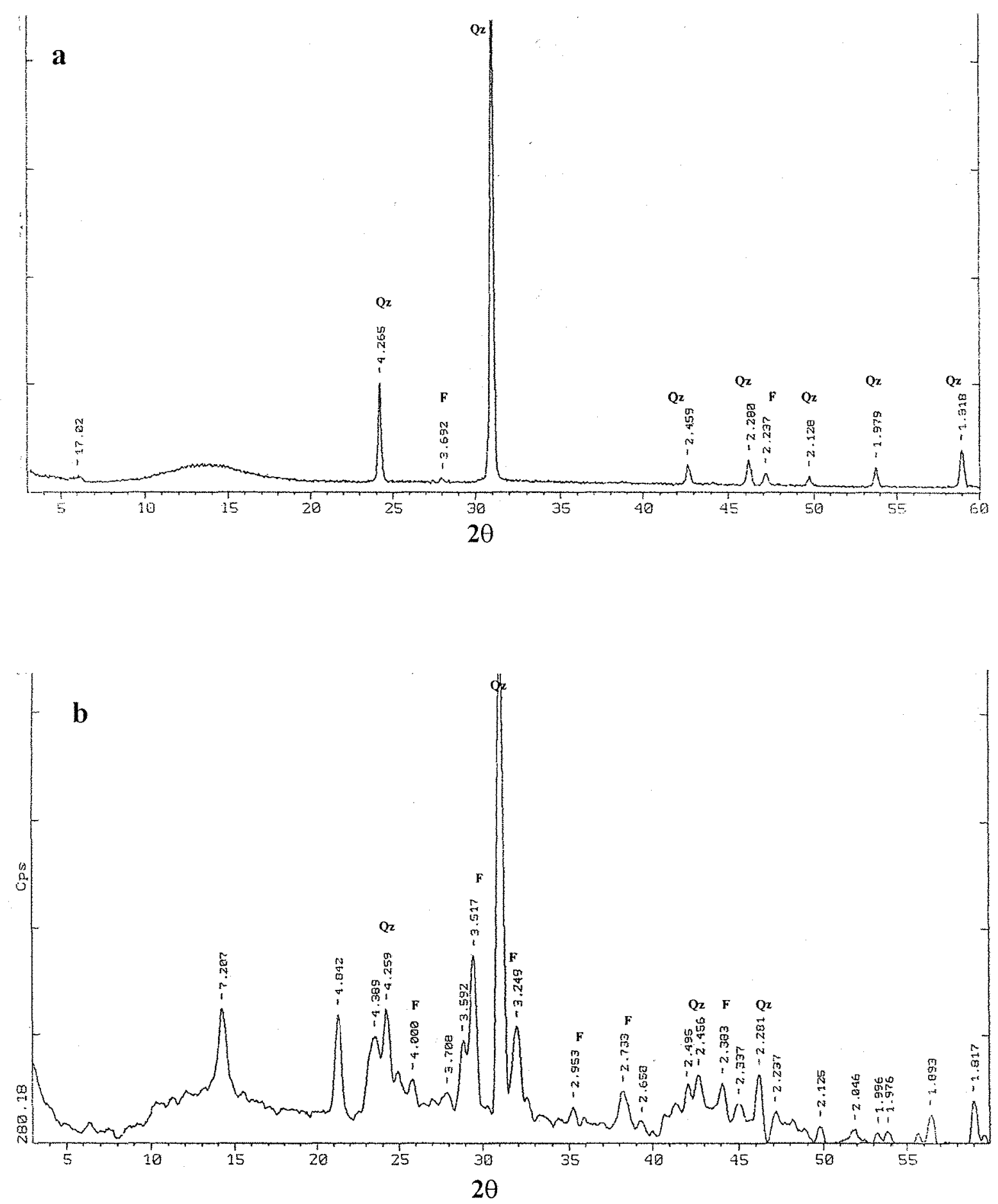

Figura 15 - Difratogramas de raios-X das frações areia (a) e silte (b) deferrificadas do horizonte subsuperficial do LAw-1 $(\mathrm{Qz}=$ quartzo; $\mathrm{F}=$ feldspato) 

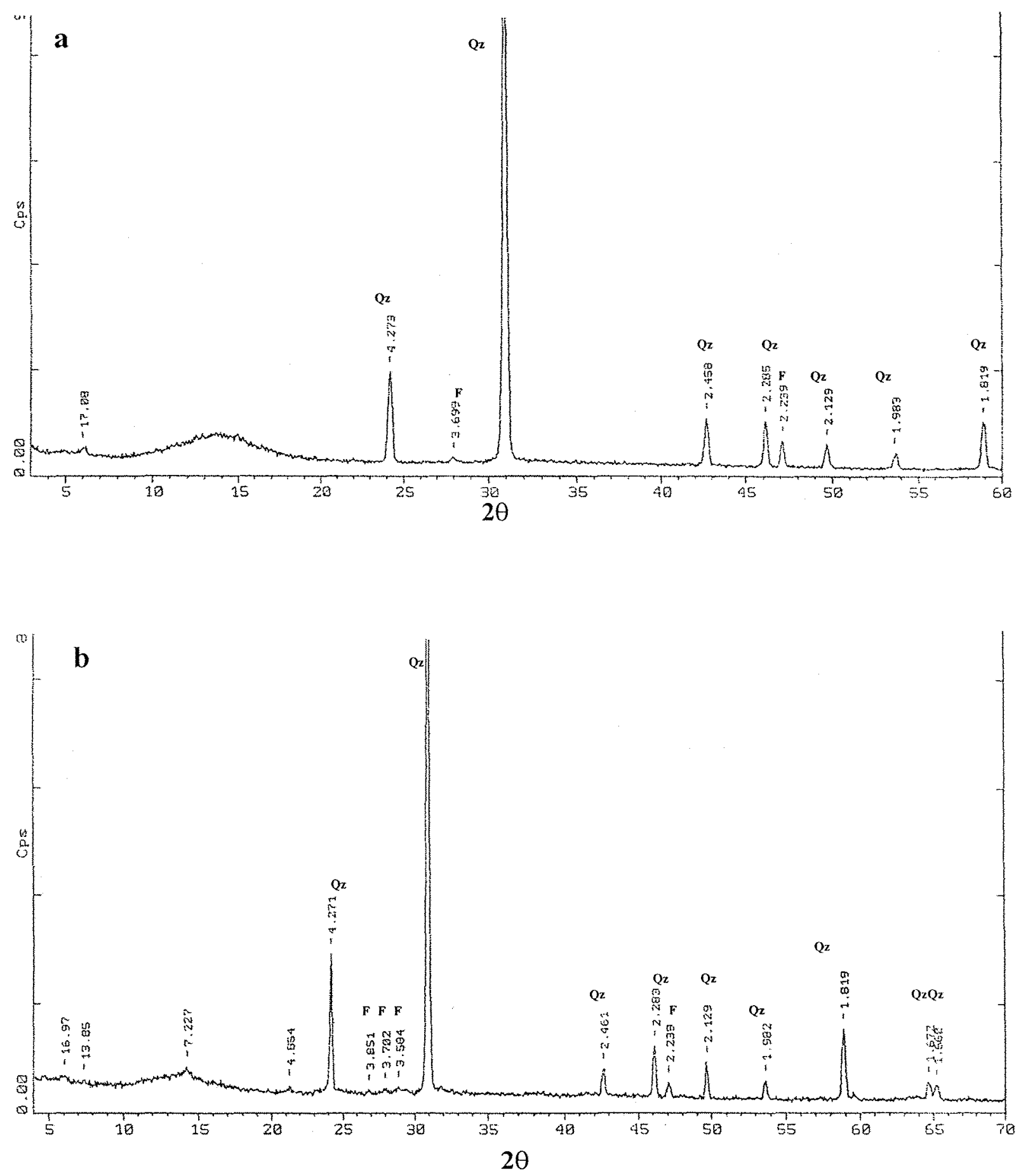

Figura 16 - Difratogramas de raios-X das frações areia (a) e silte (b) deferrificadas do horizonte subsuperficial do LVAw $(\mathrm{Qz}=$ quartzo; $\mathrm{F}=$ feldspato $)$ 

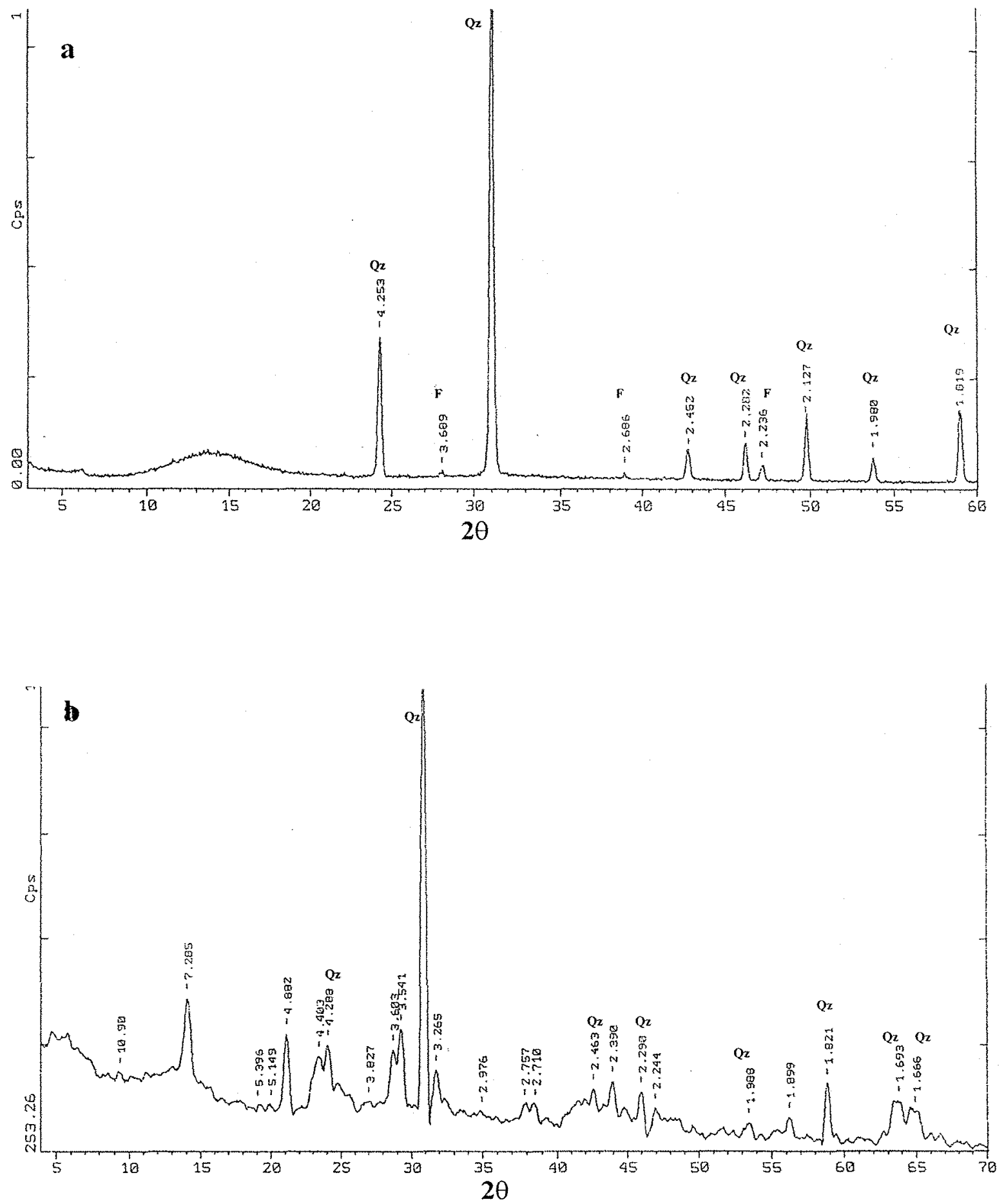

Figura 17 - Difratogramas de raios-X das frações areia (a) e silte (b) deferrificadas do horizonte subsuperficial do $\mathrm{LVw}(\mathrm{Qz}=$ quartzo; $\mathrm{F}=$ feldspato $)$ 

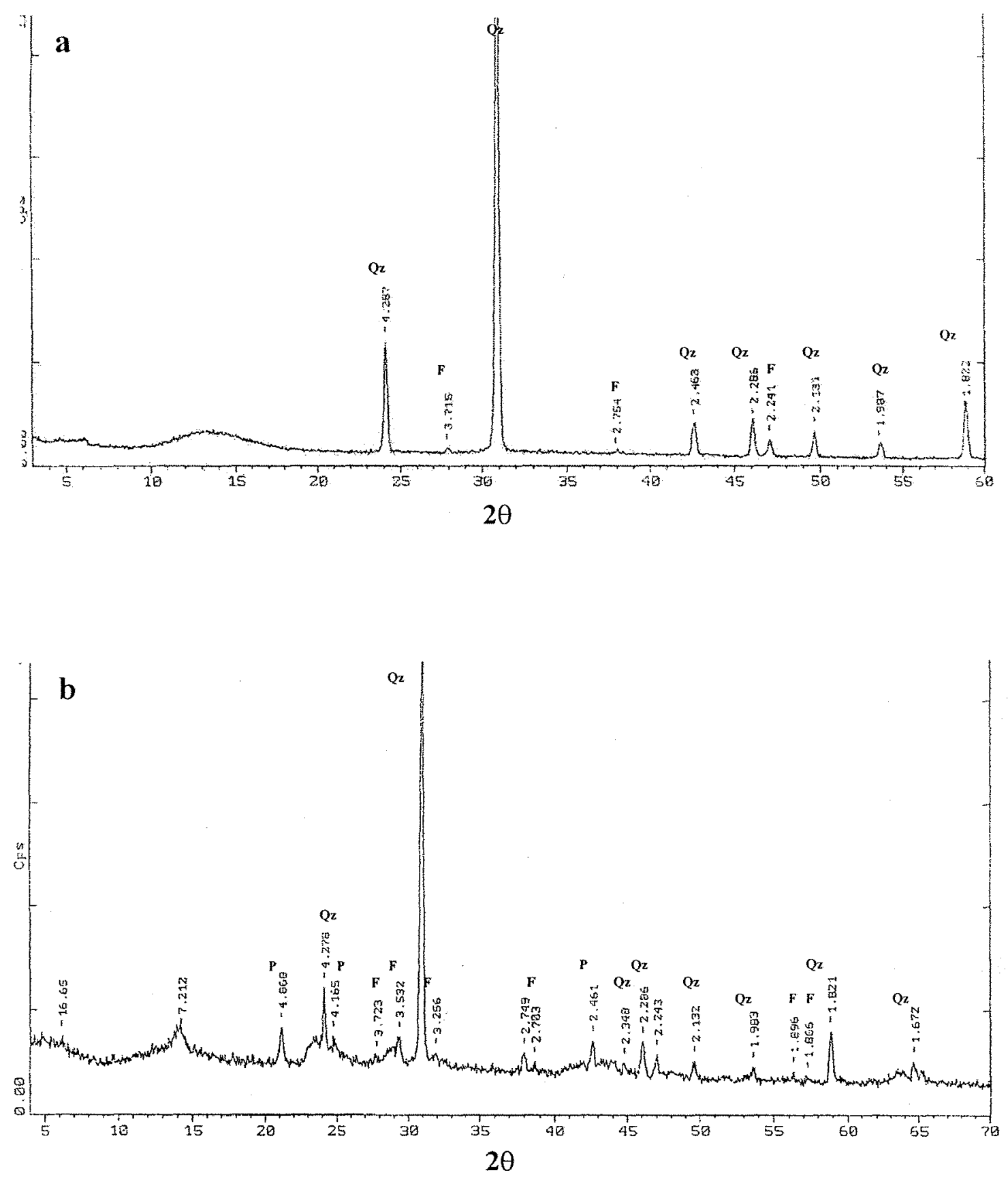

Figura 18 - Difratogramas de raios-X das frações areia (a) e silte (b) deferrificadas do horizonte subsuperficial do LAw-2 $(\mathrm{Qz}=$ quartzo; $\mathrm{F}=$ feldspato; $\mathrm{P}=$ pirofilita) 

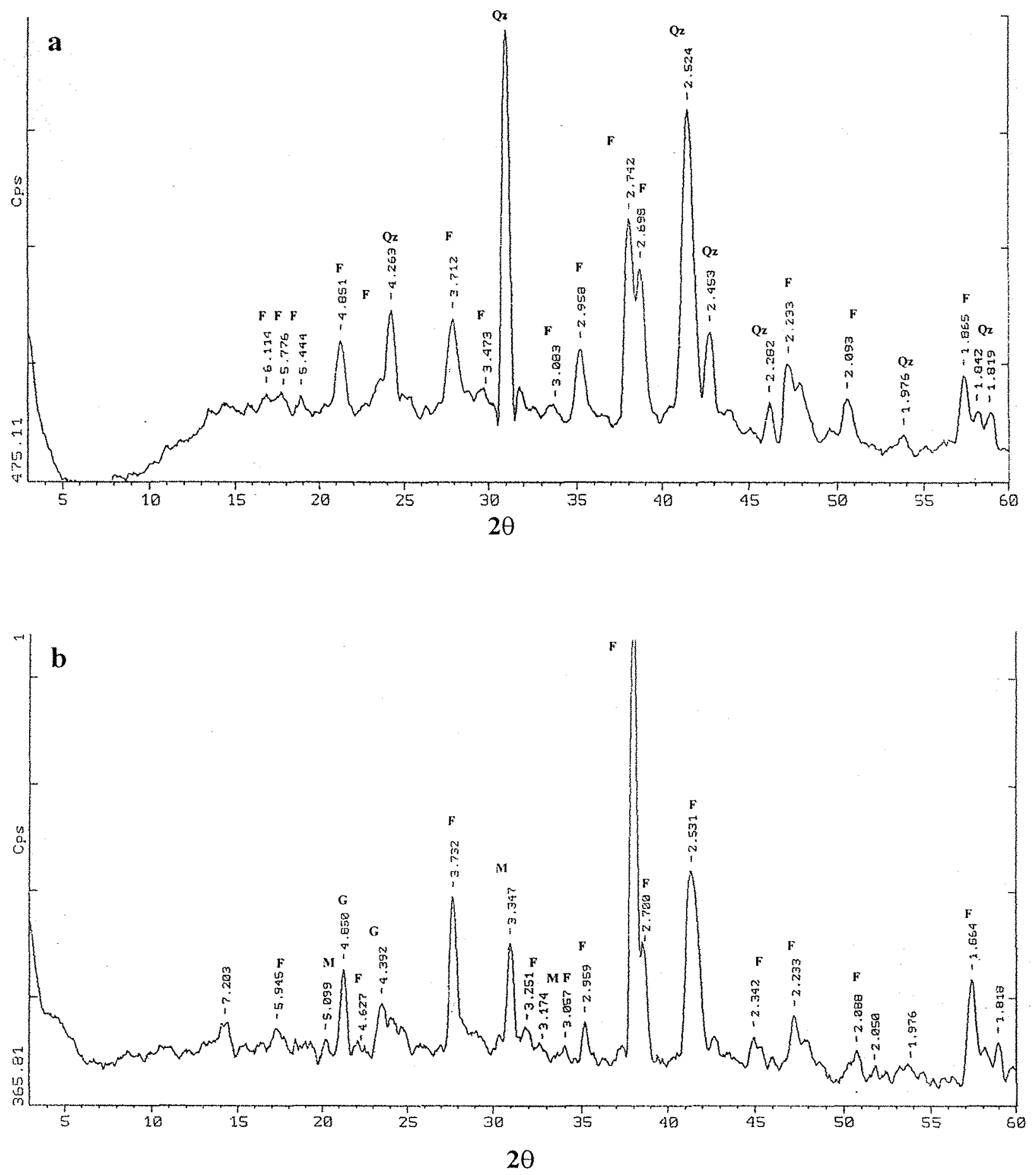

Figura 19 - Difratogramas de raios-X das frações areia (a) e silte (b) deferrificadas do horizonte subsuperficial do $\operatorname{LVwf}(\mathrm{Qz}=$ quartzo; $\mathrm{F}=$ feldspato; $\mathrm{M}=$ mica; $\mathrm{G}$ $=$ gibbsita). 

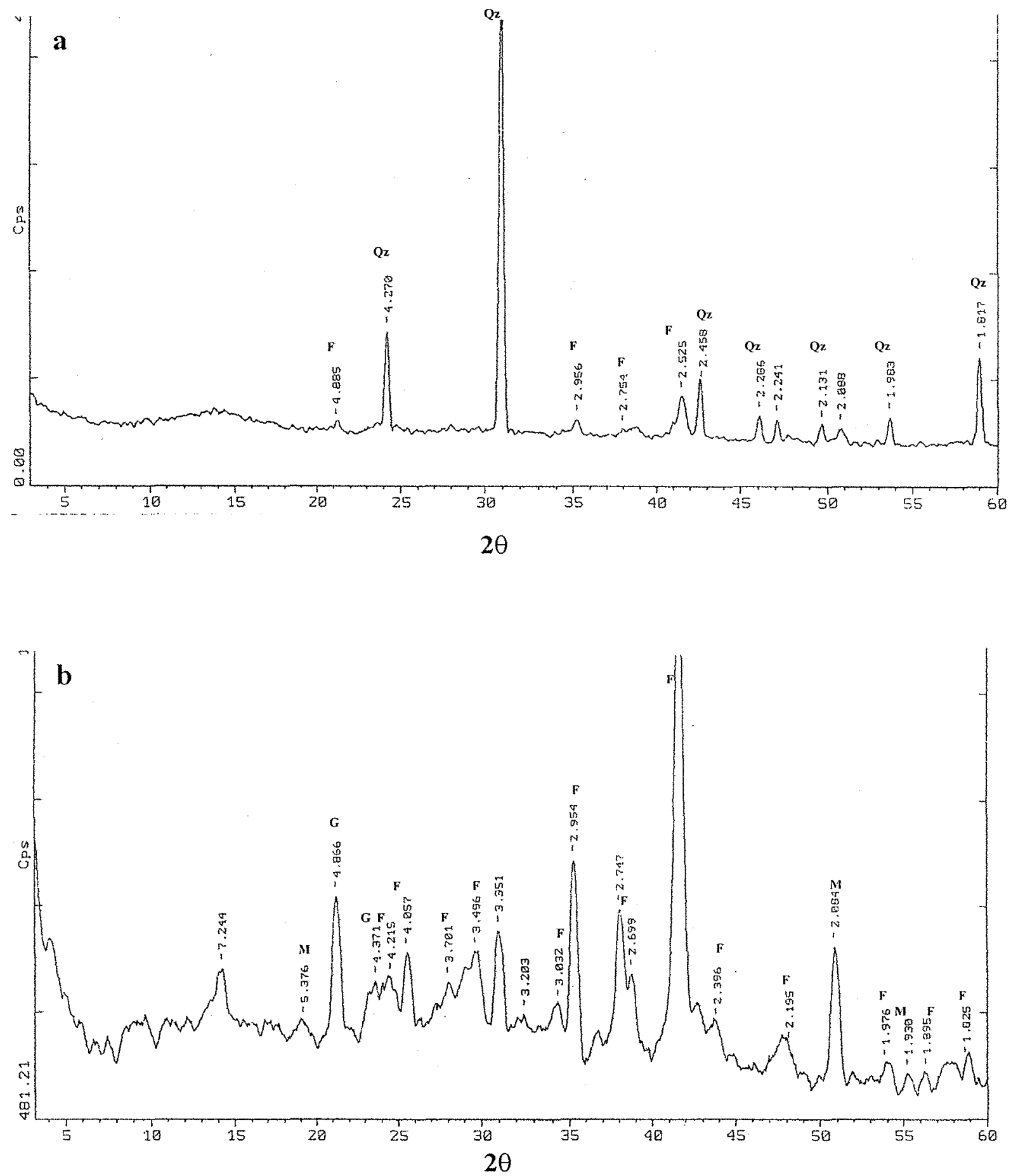

Figura 20 - Difratogramas de raios-X das frações areia (a) e silte (b) deferrificadas do horizonte subsuperficial do NVef ( $F=$ feldspato; $M=$ mica; $Q z=$ quartzo; $G$ $=$ gibbsita) 

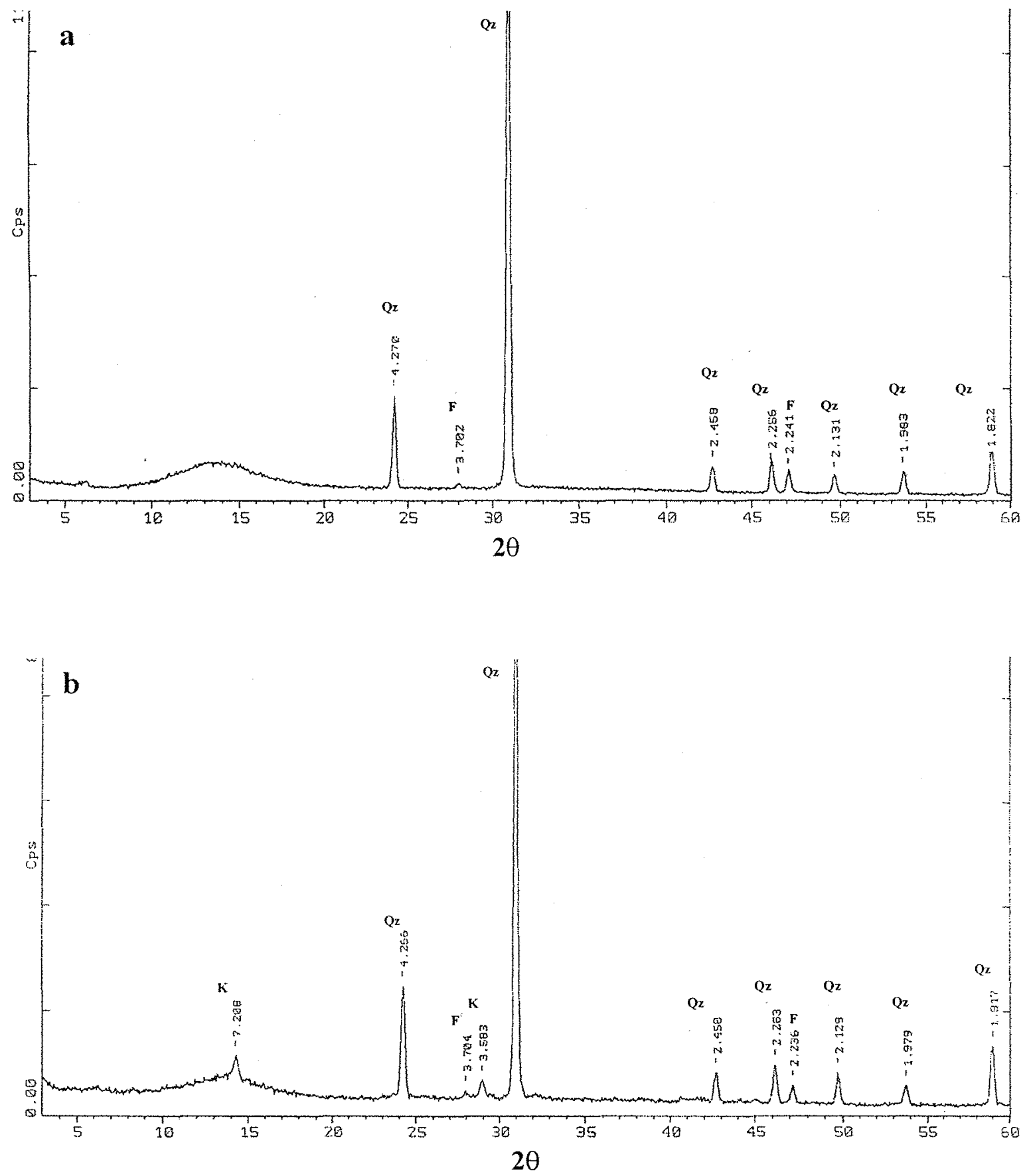

Figura 21 - Difratogramas de raios-X das frações areia (a) e silte (b) deferrificadas do horizonte subsuperficial do $\mathrm{RQo}(\mathrm{Qz}=$ quartzo; $\mathrm{F}=$ feldspato; $\mathrm{K}=$ caulinita $)$. 

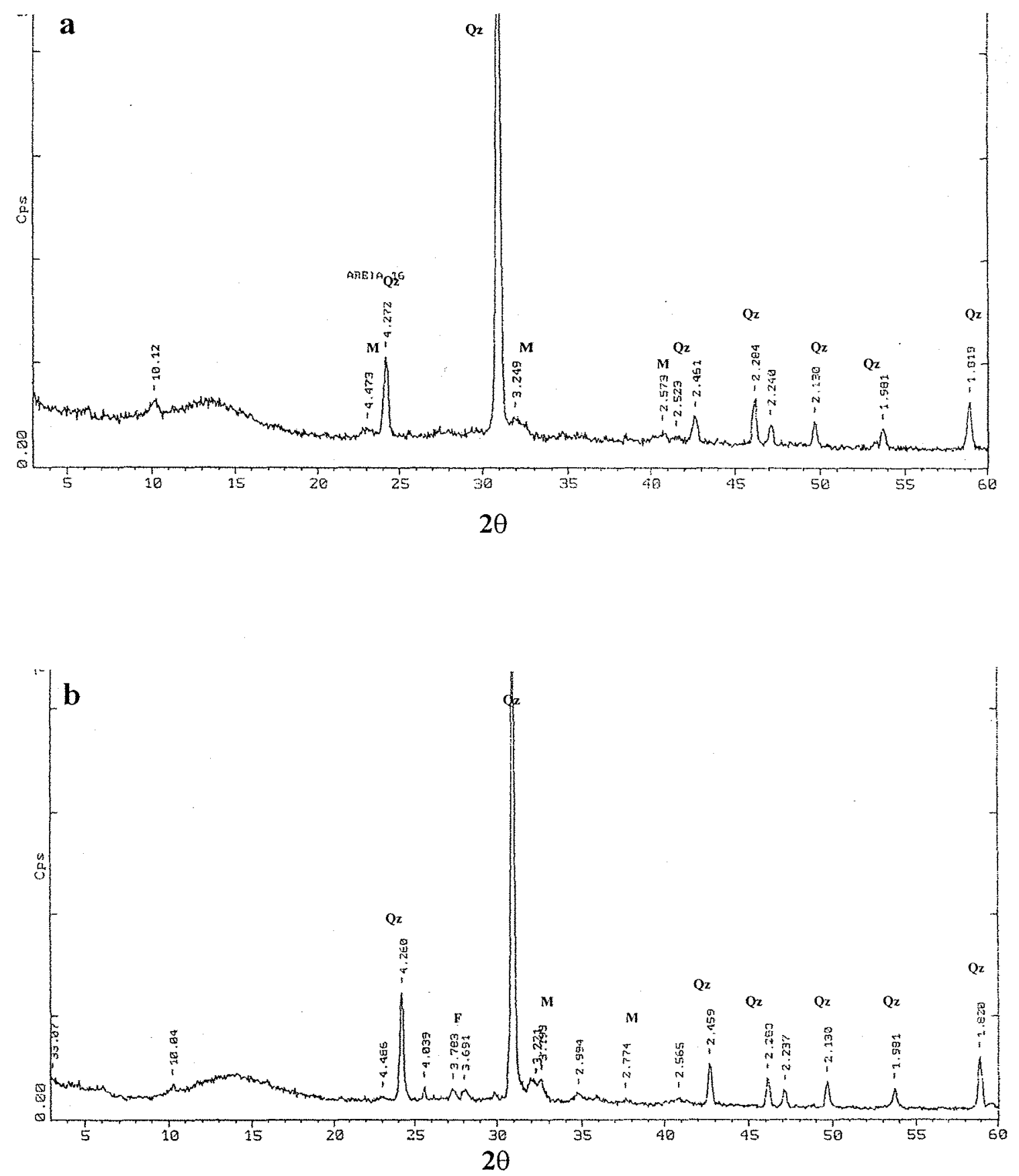

Figura 22- Difratogramas de raios- $X$ das frações areia (a) e silte (b) deferrificadas do horizonte subsuperficial do RLe $(\mathrm{Qz}=$ quartzo; $\mathrm{F}=$ feldspato; $\mathrm{M}=$ mica $)$ 

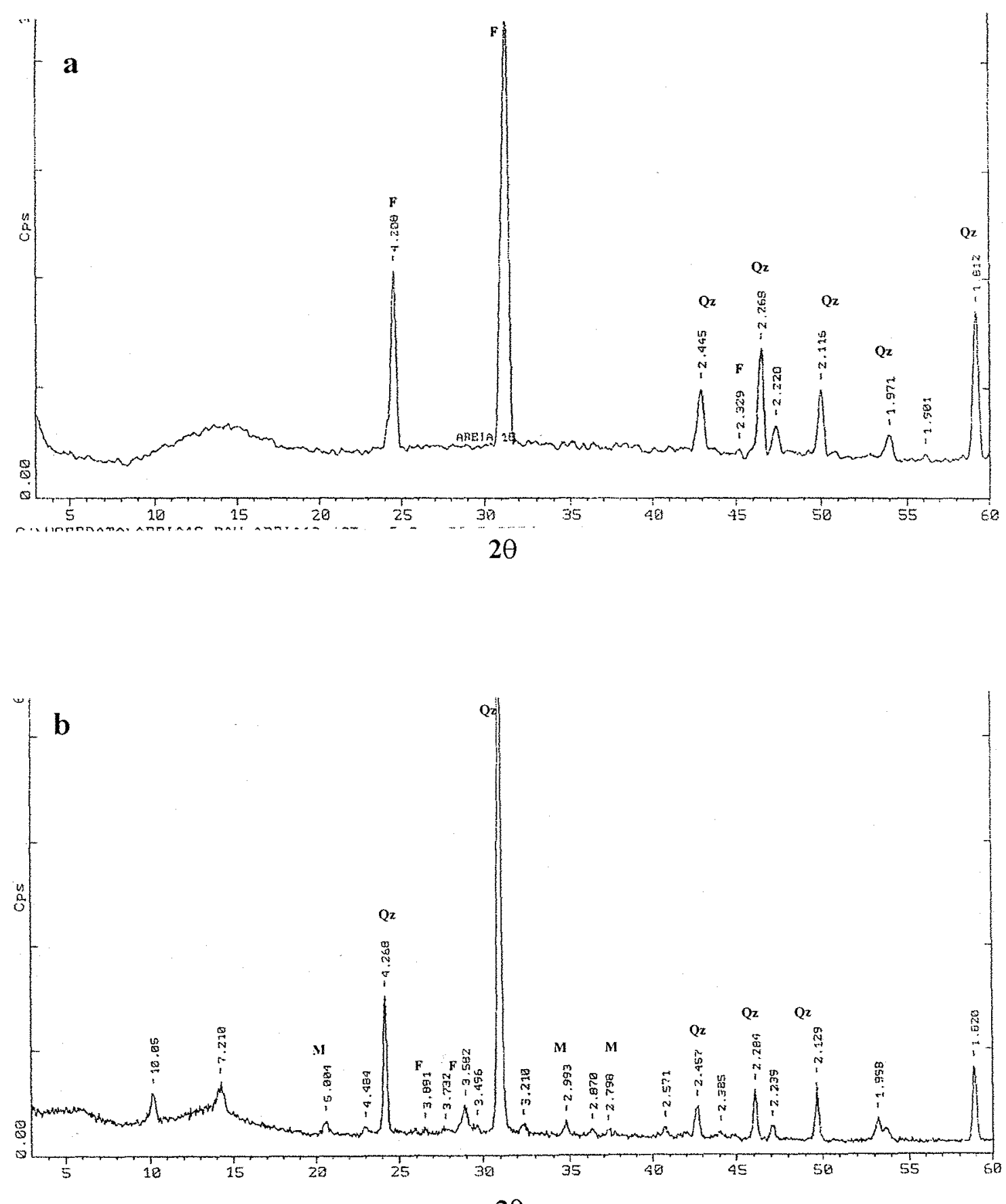

$2 \theta$

Figura 23 - Difratogramas de raios-X das frações areia (a) e silte (b) deferrificadas do horizonte subsuperficial do $\mathrm{CXbd}-1(\mathrm{Qz}=$ quartzo; $\mathrm{F}=$ feldspato; $\mathrm{M}=$ mica) 

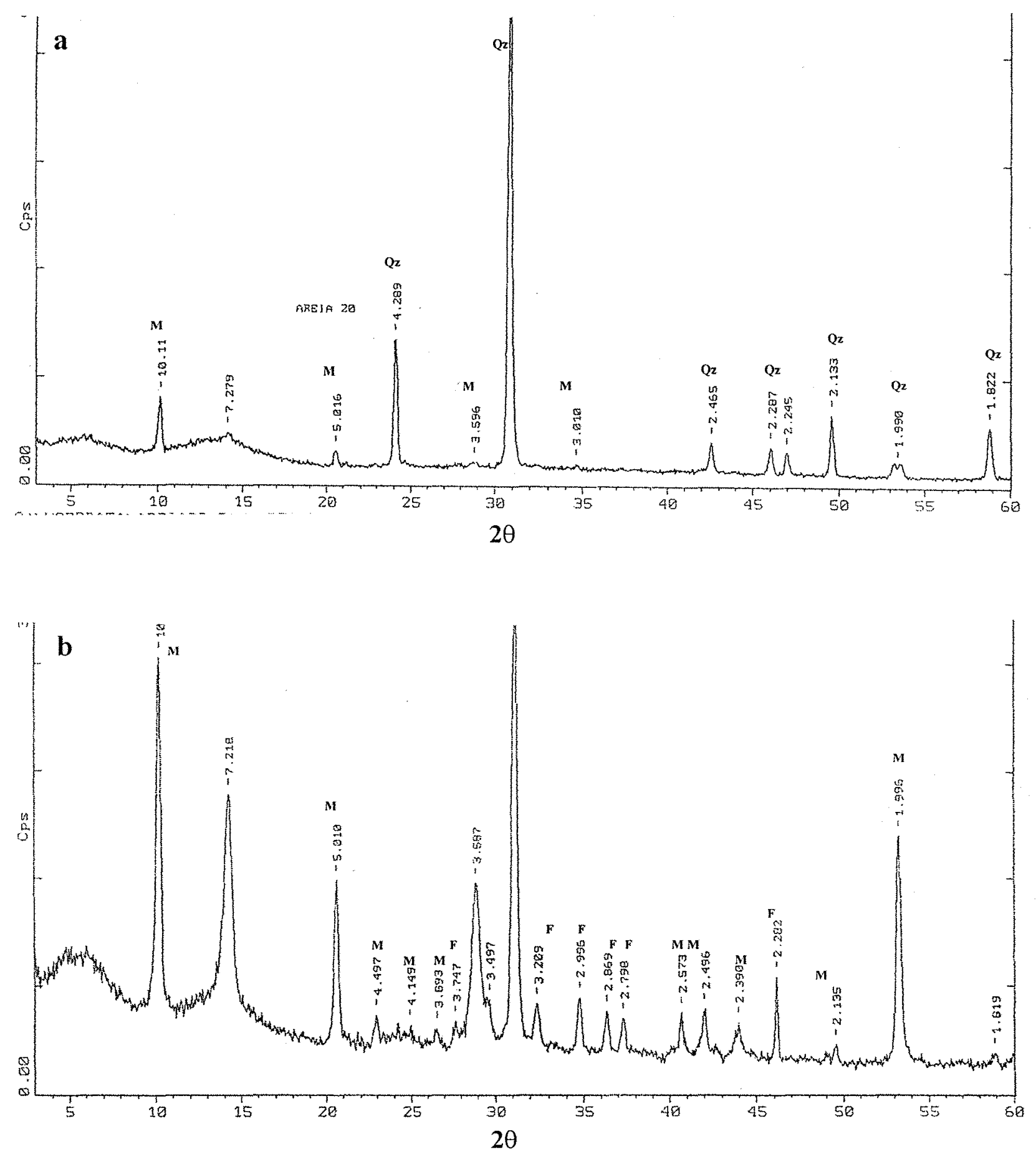

Figura 24 - Difratogramas de raios-X das frações areia (a) e silte (b) deferrificadas do horizonte subsuperficial do $\mathrm{CXbd}-2(\mathrm{Qz}=$ quartzo; $\mathrm{F}=$ feldspato; $\mathrm{M}=$ mica) 

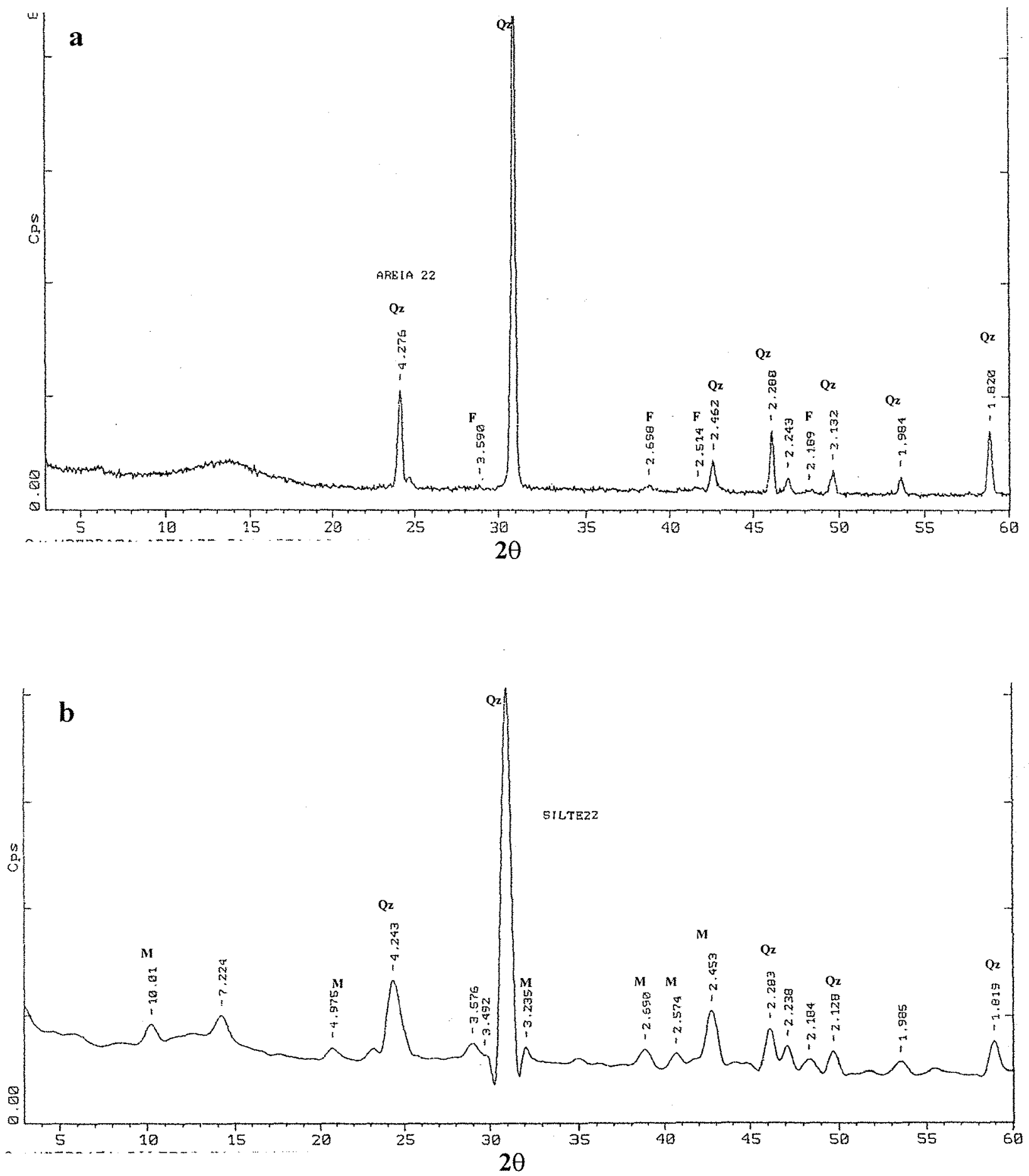

Figura 25 - Difratogramas de raios-X das frações areia (a) e silte (b) deferrificadas do horizonte subsuperficial do $F X d(Q z=$ quartzo; $F=$ feldspato; $M=$ mica $)$ 


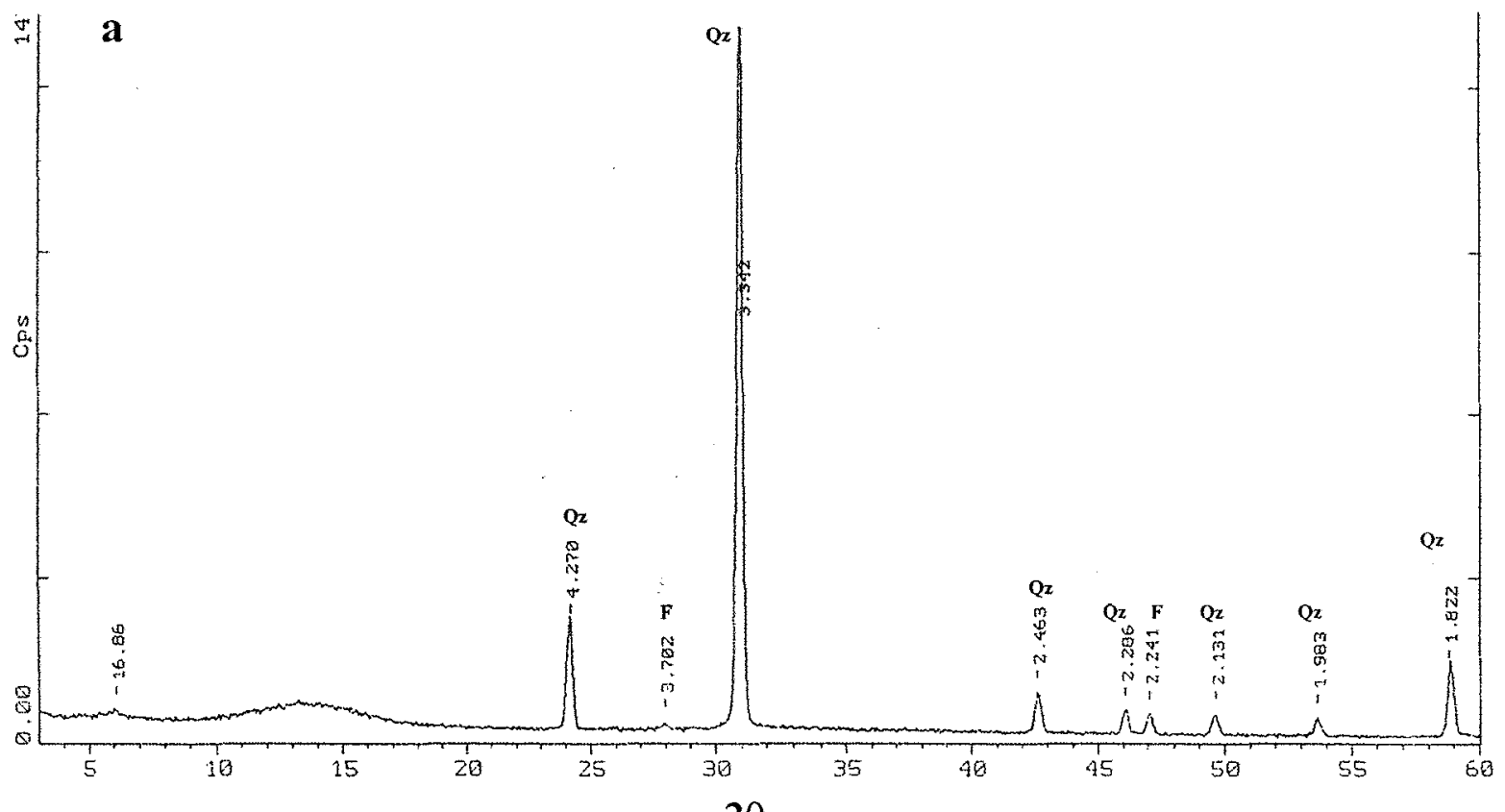

$2 \theta$

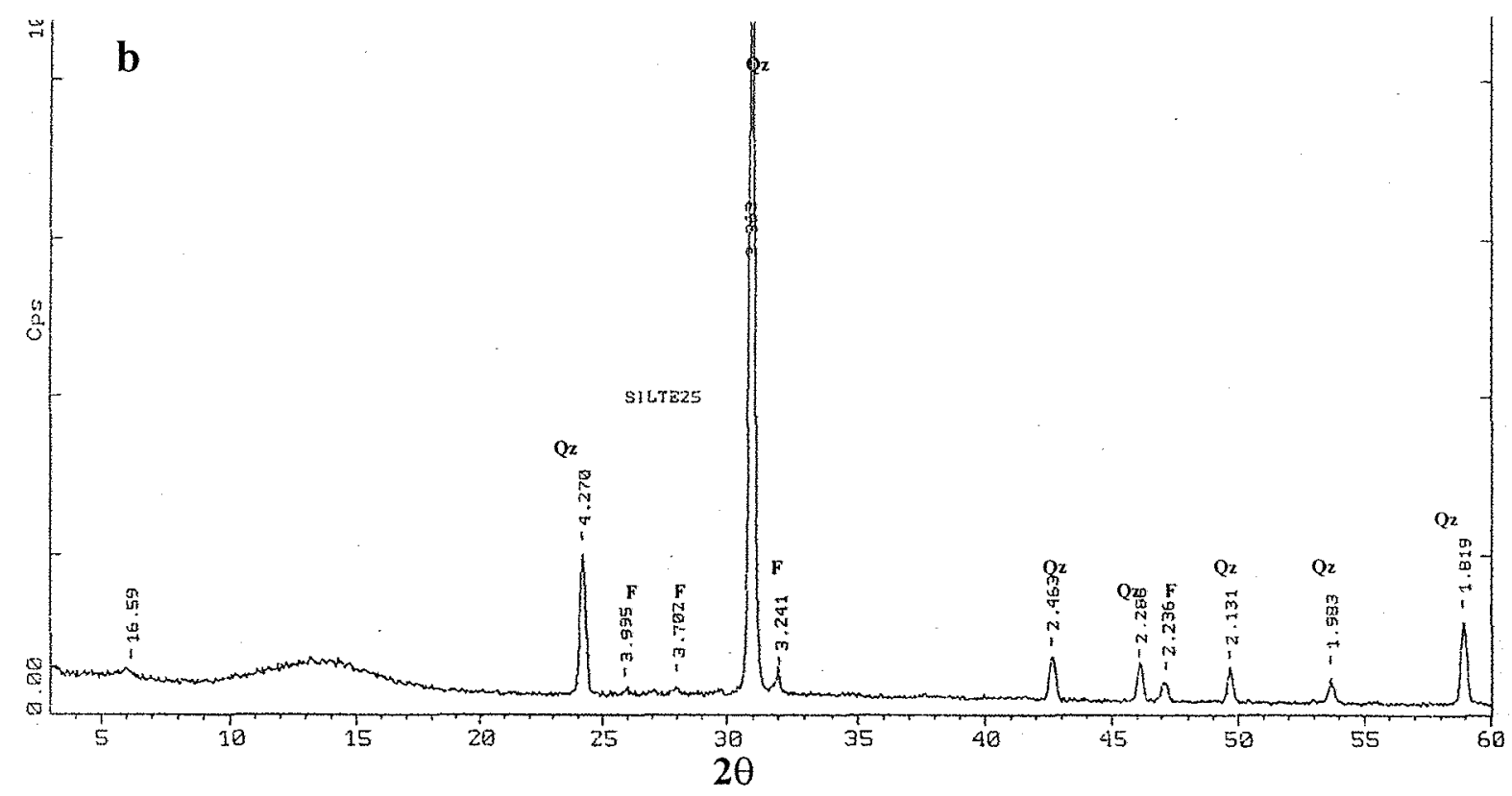

Figura 26 - Difratogramas de raios-X das frações areia (a) e silte (b) deferrificadas do horizonte subsuperficial do PVAd $(\mathrm{Qz}=$ quartzo; $\mathrm{F}=$ feldspato $)$. 
Esmectitas podem ser produtos de feldspatos em Inceptssols. Caulinita foi descrita como o produto imediato do intemperismo do plagioclásio em Alfissolos desenvolvidos de rochas básicas (Huang, 1989).

$\mathrm{Na}$ fração silte de algumas amostras foram detectadas gibbsita e caulinita que possivelmente não tenham sofrido dispersão e mantiveram-se como agentes cimentantes. O LVwf e o NVef apresentaram mica em sua fração silte, mas não na fração areia. O quartzo esteve ausente da fração silte destes solos, ocorrendo o predominio de feldspatos (oligoclásio, plagioclásio e ortoclásio). A mineralogia do RQo é semelhante para as frações silte e areia, nas quais predominam quartzo e oligoclásio. A fração areia do RLe é dominada por mica e quartzo, aparecendo ainda feldspatos na fração silte. Micas também aparecem nas frações areia e silte do CXbd-2 e silte do CXbd-1 e FXd. Oligoclásio e quartzo são os únicos componentes minerais do silte e da areia do PVAd.

Evidências da presença de biotita em areia e silte de muitos Ultissols e Inceptissols foram observadas por Fanning et al. (1989). A estabilidade deste mineral pode ser afetada pelos recobrimentos de óxidos de ferro. Vermiculita é descrita como o primeiro produto de alteração da biotita em ambientes próximos à superfície. Outros filossilicatos 2:1 e caulinita também são subprodutos de biotita. Muscovita é predominante em rochas ígneas, gnaisses e xistos e componente de muitos arenitos.

\subsection{Correlação entre $\mathrm{CTC}_{\mathrm{e}}$ calculada e determinada}

A determinação da CTC pode ser feita por diversos métodos com soluções tamponados ou não, empregando cátions índices. Estudos comparativos foram conduzidos por diversos autores (Raij, 1966; Gillman, 1979; 1986). Discrepâncias entre a CTC determinada pelos métodos compulsivos (Gillman, 1979) e pelo 
somatório de cátions trocáveis, incluindo $\mathrm{Al}$ e $\mathrm{H}$ (CTC efetiva) são também descritas na literatura.

Estas diferenças foram encontradas em solos que variam consideravelmente nas propriedades e gênese, sugerindo que muitos processos podem estar envolvidos. Dessa forma, esperavam-se resultados discrepantes para os solos estudados, o que não foi confirmado frente ao alto coeficiente de determinação obtido (Figura 27).

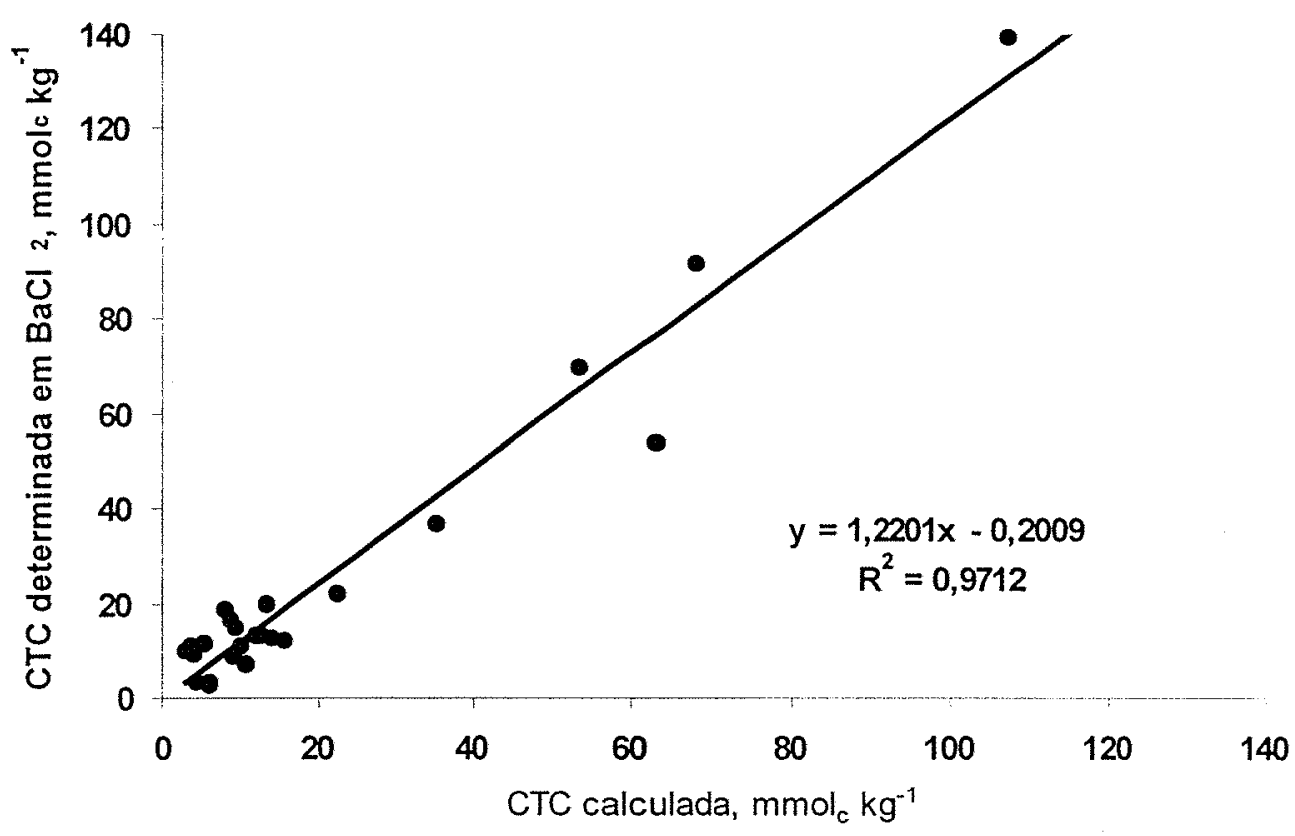

Figura 27. Correlação entre diferentes métodos de determinação da $\mathrm{CTC}_{\mathrm{e}}$.

Ranst et al. (1998) obtiveram valores similares ao determinarem a CTC em solução não tamponada e em solução de $\mathrm{NH}_{4} \mathrm{OAc}$ a pH 7,0, apesar de o último alterar o pH e a força iônica da solução. A manutenção do $\mathrm{pH}$ da solução extratora em torno de 5 pode ter evitado a dissolução do $\mathrm{Al}$ e, conseqüentemente, uma superestimativa da CTC efetiva. Nestes valores de $\mathrm{pH}$, os cátions básicos dominam o complexo de troca, e o Al está na sua forma trocável. O impacto das 
soluções que elevam o pH e alteram a força iônica da solução é relevante em solos com grandes quantidades de colóides com carga elétrica variável.

\section{5 pH de abrasão}

As amostras de areia fina + areia média dos solos, cujo material de origem é arenito, apresentaram baixos valores de $\mathrm{pH}$ de abrasão que podem ser atribuídos ao quartzo, que predomina na fração areia e possui pH de abrasão em torno de 6,0 (Olier,1969). Por serem originados de rocha básica, o LAw-2, LVwf e NVef possuem alto $\mathrm{pH}$ de abrasão. Presume-se que isso seja decorrência do acúmulo de cátions em suas frações grosseiras, principalmente nos feldspatos, minerais que, de acordo com a análise mineralógica, predominam juntamente com o quartzo, por serem mais estáveis

A cobertura detrito-latossólica que originou o LAw-1 e o LVw dá indicativos de grande heterogeneidade na sua composição, evidenciada pelos distintos valores de $\mathrm{pH}$ de abrasão do LAw-1 e LVw. Embora datado do Terciário/Quaternário, o sedimento possui matriz argilosa anteriormente intemperizada, sendo que a fração grosseira, em estádio menos avançado de intemperismo, pode responder pela heterogeneidade dos valores de $\mathrm{pH}$ de abrasão. A composição mineralógica da fração areia total de ambos os solos é idêntica. Provavelmente, os feldspatos podem ter se acumulado na fração areia média+fina do LAw-1, conferindo-lhe maior $\mathrm{pH}$ de abrasão. Por outro lado, o menor valor de $\mathrm{pH}$ de abrasão do $\mathrm{LVw}$ dá indicativos que o quartzo predomina na fração $0,100-0,500 \mathrm{~mm}$.

Ferrari \& Magaldi (1983) estudaram solos sedimentares e os agruparam de acordo com diferentes idades de formação, obtendo altas correlações entre $\mathrm{pH}$ de abrasão e pH do solo, que os levaram a estabelecer o índice $\mathrm{DpH}$. Os valores de 
pH de abrasão e o $\mathrm{DpH}$ dos solos estudados neste trabalho estão contidos na tabela 8 .

Tabela 8. Valores de pH de abrasão e índice $\mathrm{DpH}$ calculado.

\begin{tabular}{|c|c|c|c|c|c|}
\hline Material de origem & Solo & Profundidade & $\mathrm{pH}_{\text {abrasāo }}$ & $\mathrm{pH}_{\mathrm{H} 2 \mathrm{O}}$ & $\mathrm{DpH}$ \\
\hline \multirow{8}{*}{ arenito } & & $\mathbf{m}$ & & & \\
\hline & LVAw & $0,0-0,2$ & 5,8 & 4,3 & 1,5 \\
\hline & & $0,8-1,2$ & 5,9 & 4,8 & 1,1 \\
\hline & RQo & $0,0-0,15$ & 4,9 & 5,0 & $-0,1$ \\
\hline & & $0,4-0,8$ & 5,2 & 4,3 & 0,9 \\
\hline & PVAd & $0,0-0,3$ & 6,3 & 5,4 & 0,9 \\
\hline & & $0,3-0,8$ & 5,5 & 5,3 & 0,2 \\
\hline & & $0,8-1,2$ & 4,6 & 4,2 & 0,4 \\
\hline \multirow{6}{*}{ basalto } & LAw-2 & $0,0-0,2$ & 6,8 & 4,6 & 2,2 \\
\hline & & $1,0-1,3$ & 7,7 & 5,1 & 2,6 \\
\hline & LVwf & $0,0-0,2$ & 9,8 & 6,4 & 3,4 \\
\hline & & $1,0-1,5$ & 9,9 & 5,3 & 4,6 \\
\hline & NVef & $0,0-0,2$ & 9,1 & 5,7 & 3,4 \\
\hline & & $0,7-0,9$ & 7,7 & 6,0 & 1,7 \\
\hline \multirow{4}{*}{$\begin{array}{l}\text { sedimentos } \\
\text { inconsolidados }\end{array}$} & LAw-1 & $0,0-0,2$ & 7,7 & 4,5 & 3,2 \\
\hline & & $0,8-1,2$ & 8,1 & 4,8 & 3,3 \\
\hline & LVw & $0,0-0,2$ & 5,4 & 4,5 & 0,9 \\
\hline & & $0,8-1,2$ & 5,5 & 4,8 & 0,7 \\
\hline \multirow{8}{*}{ Outros } & RLe & $0,0-0,05$ & 9,5 & 5,5 & 4,0 \\
\hline & & $0,05-0,15$ & 9,1 & 5,6 & 3,5 \\
\hline & CXbd-1 & $0,0-0,2$ & 8,3 & 4,2 & $4, I$ \\
\hline & & $0,4-0,8$ & 7,4 & 4,5 & 2,9 \\
\hline & CXbd-2 & $0,0-0,2$ & 10,1 & 4,7 & 5,4 \\
\hline & & $0,6-0,8$ & 9,9 & 4,7 & 5,2 \\
\hline & FXd & $0,0-0,2$ & 6,8 & 4,4 & 2,4 \\
\hline & & $0,6-0,8$ & 6,6 & 4,4 & 2,2 \\
\hline
\end{tabular}

A diferença entre $\mathrm{pH}$ do solo, medido em água, e o $\mathrm{pH}$ de abrasão fornece estimativa do grau de intemperismo dos solos, considerando a forte relação existente entre os dois valores (Ferrari \& Magaldi, 1983). Dessa forma, antes de empregar o índice $\mathrm{DpH}$ aos solos estudados, julgou-se pertinente estabelecer a relação entre o pH do solo e o pH de abrasão. Como o pH do solo é um atributo passível de modificações por atividade antrópica, consideraram-se os valores dos 
horizontes subsuperficiais. Os coeficientes de correlação encontrados não indicaram boa relação entre $\mathrm{pH}$ de abrasão e $\mathrm{pH}$ do solo e, portanto, o índice $\mathrm{DpH}$ não se adequou aos solos estudados como índice de intemperização.

O horizonte câmbico, típico do CXbd-1 e CXbd-2, caracteriza-se por conter feldspatos, micas e outros minerais meteorizáveis. A possível existência desses minerais, face a quantidade de material grosseiro similar ao material de origem ao longo do perfil, pode ter influenciado os altos valores de $\mathrm{pH}$ de abrasão, principalmente para $\mathrm{CXbd}-2$, cuja rocha de origem é rica em minerais micáceos. A análise mineralógica revelou a existência de feldspatos no CXbd-1 e minerais micáceos no CXbd-2. A aceleração da hidrólise pela moagem da fração areia pode ter liberado o íon potássio dos minerais micáceos, elevando o $\mathrm{pH}$ de abrasão do CXbd-2 próximo a 10 . O mesmo raciocínio pode ser seguido para o alto $\mathrm{pH}$ de abrasão do $\mathrm{CXbd}-1$, que possivelmente tenha liberado cátions $(\mathrm{Ca}, \mathrm{K}$ ou $\mathrm{Na}$ ) da estrutura de seus feldspatos ao sofrer moagem. Isso também se aplica ao perfil do RLe, cujo material grosseiro contem minerais micáceos em grande quantidade. Em resumo, todos os solos originados de arenito apresentaram $\mathrm{pH}$ de abrasão baixos, atribuídos ao predomínio do quartzo. Em contrapartida, os feldspatos dos solos originados de basalto e os minerais micáceos presentes nos CAMBISSOLOS e no NEOSSOLO LITÓLICO conferem à fração areia altos pHs de abrasão.

Macias \& Chesworth (1992) encontraram correlação entre o pH de abrasão e o teor de argila em Entissols e Inceptssols. Tais correlações não foram encontradas neste trabalho.

\subsection{Fração Cascalhenta}

A quantificação da fração superior a $2 \mathrm{~mm}$ dos solos dá idéia de sua distribuição espacial e da limitação imposta por estes materiais ao emprego de 
máquinas e equipamentos agrícolas (Tabela 9). Além disso, qualifica áreas em que a presença superficial e subsuperficial de materiais pedregosos interfere no uso das terras. Essa quantificação abrange as classes de pedregosidade, (Embrapa, 1999). Com exceção do NEOSSOLO LITÓLICO (RLe), cuja espessura até o contato lítico não excedeu $0,5 \mathrm{~m}$, que se enquadra na fase de pedregosidade II, todos os demais foram classificados como solos fase pedregosa $I$, que contêm frações variando de 2 a $20 \mathrm{~cm}$ em todo o perfil e até a profundidade de $40 \mathrm{~cm}$.

Tabela 9. Quantidade da fração maior que $2 \mathrm{~mm}$ nos solos cascalhentos.

\begin{tabular}{|c|c|c|c|c|c|}
\hline \multirow{2}{*}{ Solo } & \multirow{2}{*}{ Profundidade } & \multicolumn{2}{|c|}{ Cascalho } & \multirow[b]{2}{*}{ Calhaus } & \multirow{2}{*}{$\begin{array}{c}\text { Total } \\
(>2 \mathrm{~mm})\end{array}$} \\
\hline & & Fino & Grosso & & \\
\hline & m & & $\ldots \mathrm{g} \mathrm{kg}^{-}$ & . & $\ldots$ \\
\hline \multirow[t]{2}{*}{ RLe } & $0,0-0,05$ & 157,8 & 87,2 & 33,2 & 278,2 \\
\hline & $0,05-0,15$ & 171,2 & 128,5 & 89,3 & 389,0 \\
\hline \multirow[t]{2}{*}{ CXbd-1 } & $0,0-0,2$ & 205,1 & 328,3 & 242,7 & 776,2 \\
\hline & $0,4-0,8$ & 207,4 & 257,6 & 393,2 & 858,1 \\
\hline \multirow[t]{2}{*}{ CXbd-2 } & $0,0-0,2$ & 275,1 & 92,5 & 58,9 & 426,5 \\
\hline & $0,6-0,8$ & 75,2 & 34,2 & 11,5 & 120,9 \\
\hline \multirow[t]{2}{*}{ FXd } & $0,0-0,2$ & 412,6 & 254,5 & 29,2 & 696,3 \\
\hline & $0,6-0,8$ & 412,2 & 255,1 & 39,6 & 706,9 \\
\hline
\end{tabular}

A proporção de terra fina no CXbd-1 e FXd pode inviabilizar o estabelecimento de sistemas de produção agrícola, especialmente pelo impedimento físico que eles podem oferecer. Apesar de apresentar menor quantidade de cascalhos e calhaus, o RLe é um solo extremamente raso, cuja rocha de origem pode representar um sério impedimento físico à penetração radicular, tanto de plantas perenes quanto de anuais. 


\subsubsection{Análise mineralógica qualitativa}

As figuras $28,29,30$ e 31 contêm os difratogramas de raios- $X$ da fração cascalhenta do horizontes superficiais dos solos. O quartzo esteve presente em todos os solos e foi o mineral predominante no CXbd-1. Minerais micáceos (muscovita) foram detectados no RLe e no CXbd-2, certamente herdados do material de origem. A constituição mineralógica das concreções do FXd permite presumir que o material possa ter se formado a partir do transporte de minerais como caulinita, feldspato, quartzo e óxidos de ferro, principalmente goetita, oriundos de cotas mais altas da paisagem.

\subsubsection{Propriedades químicas}

Os procedimentos analíticos que envolvem a quantificação das propridades químicas dos componentes do solo não consideram a participação das frações superiores a $2 \mathrm{~mm}$. Porém, quando sua participação no volume de solo é alta, a contribuição destas frações deve ser considerada.

O RLe, derivado de siltito, destacou-se pela $\mathrm{CTC}_{\mathrm{e}}$ de suas frações maiores do que $2 \mathrm{~mm}$ que, somada à da terra fina, representou $31 \%$, em superfície e $38 \%$ em subsuperfície (Tabela 10). Dessa forma, nos primeiros $0,15 \mathrm{~m}$, a contribuição da fração com dimensões entre 2 a $20 \mathrm{~mm}$ foi, em média, 34,7\% (Figura 32 ). Ao estudarem solos desenvolvidos sobre arenito e siltito em áreas florestadas próximo de Florença (Itália), Ugolini et al. (1996) notaram que fragmentos de siltito tinham altos valores de CTC, surpreendentemente mais altos que a terra fina. $\mathrm{O}$ alto valor de $\mathrm{Mg}$ trocável, cátion que mais contribuiu para a soma de bases do RLe, provavelmente decorreu da sua liberação de minerais do tipo 2:1 durante os processos de acidificação que acompanham o intemperismo. A 


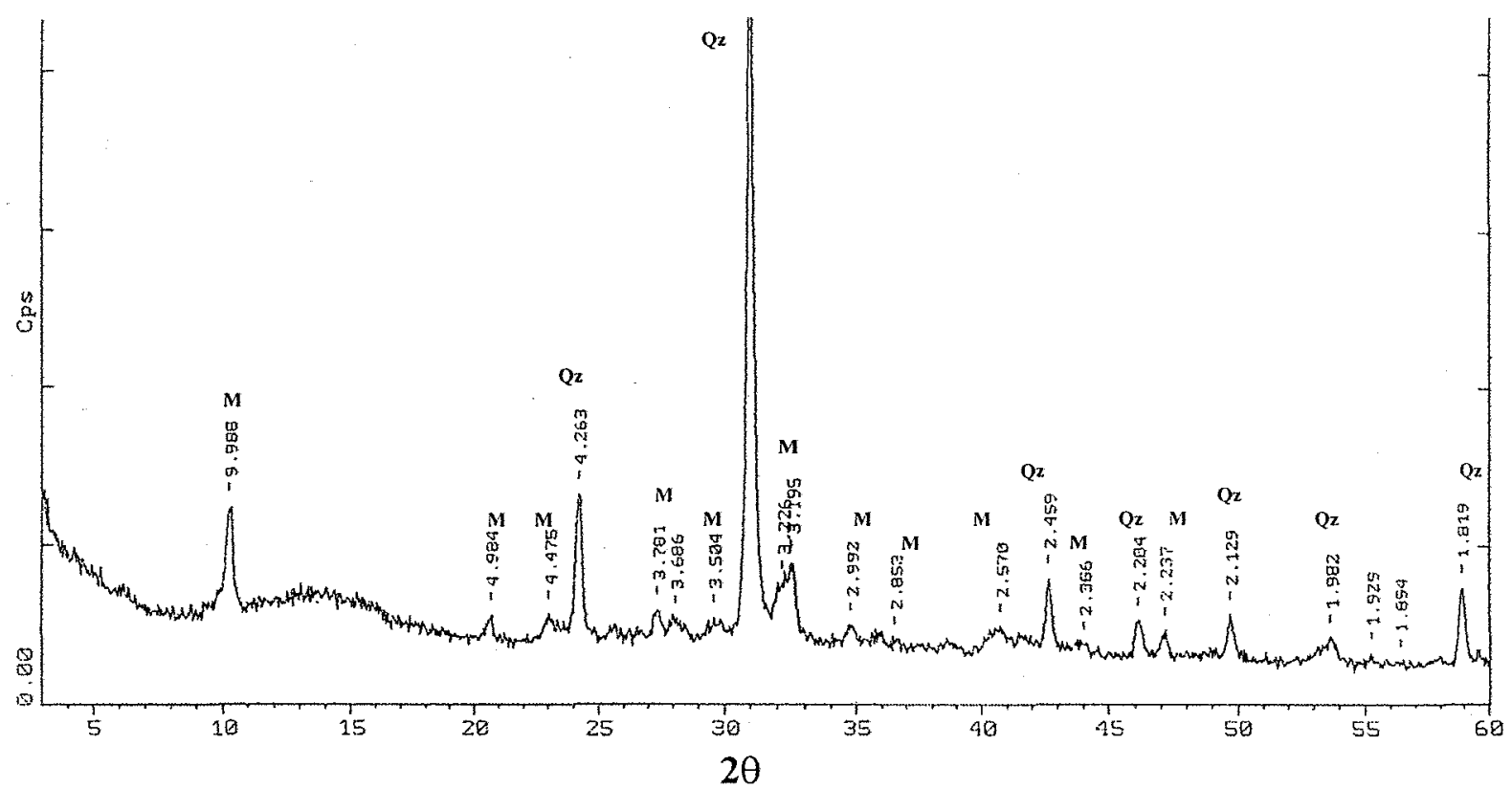

Figura 28 - Difratograma de raios-X da fração cascalhenta do horizonte subsuperficial do RLe $(\mathrm{Qz}=$ quartzo; $M=$ mica $)$

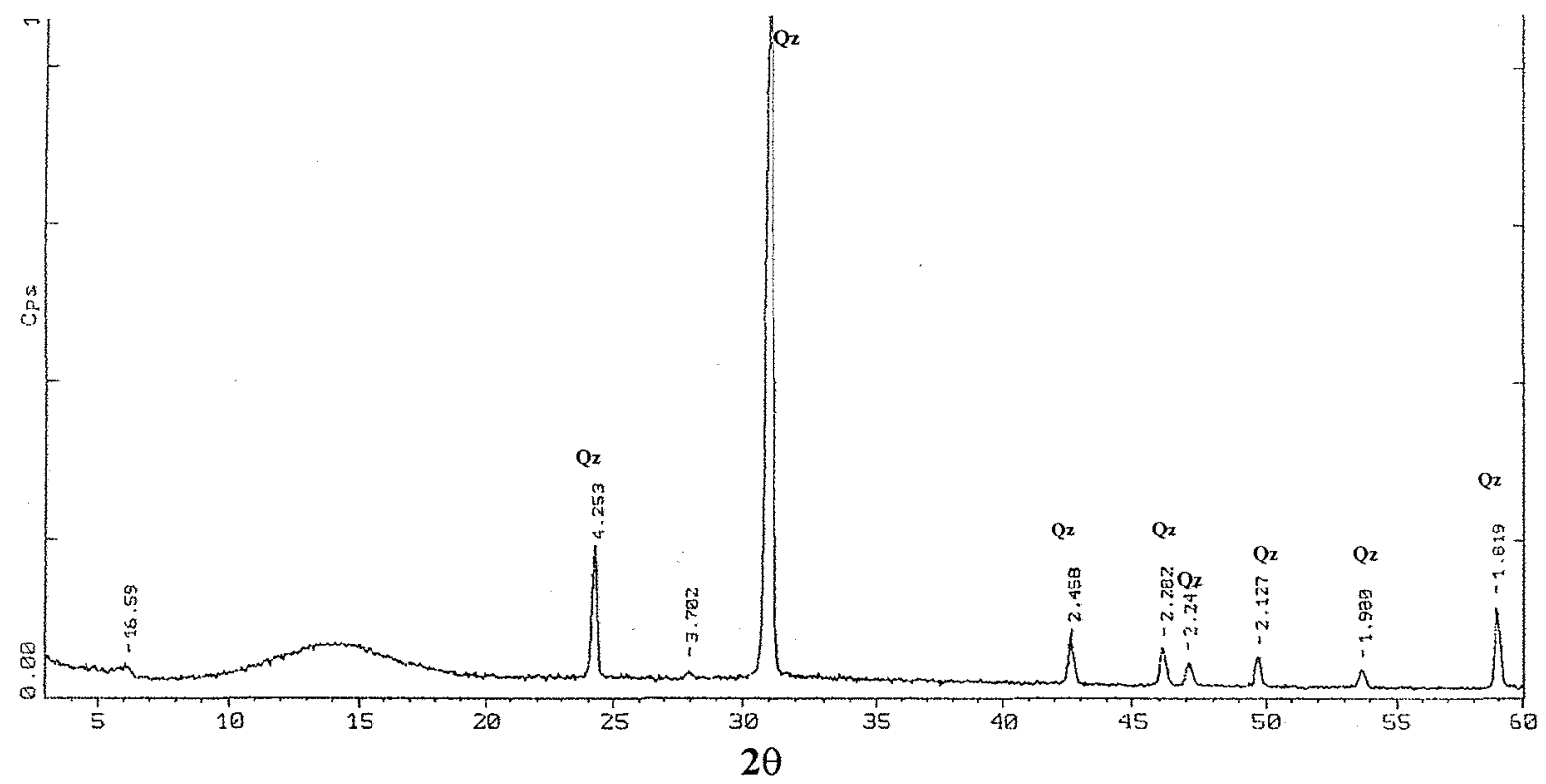

Figura 29 - Difratograma de raios-X da fração cascalhenta do horizonte subsuperficial do CXbd-1 $(\mathrm{Qz}=$ quartzo $)$ 


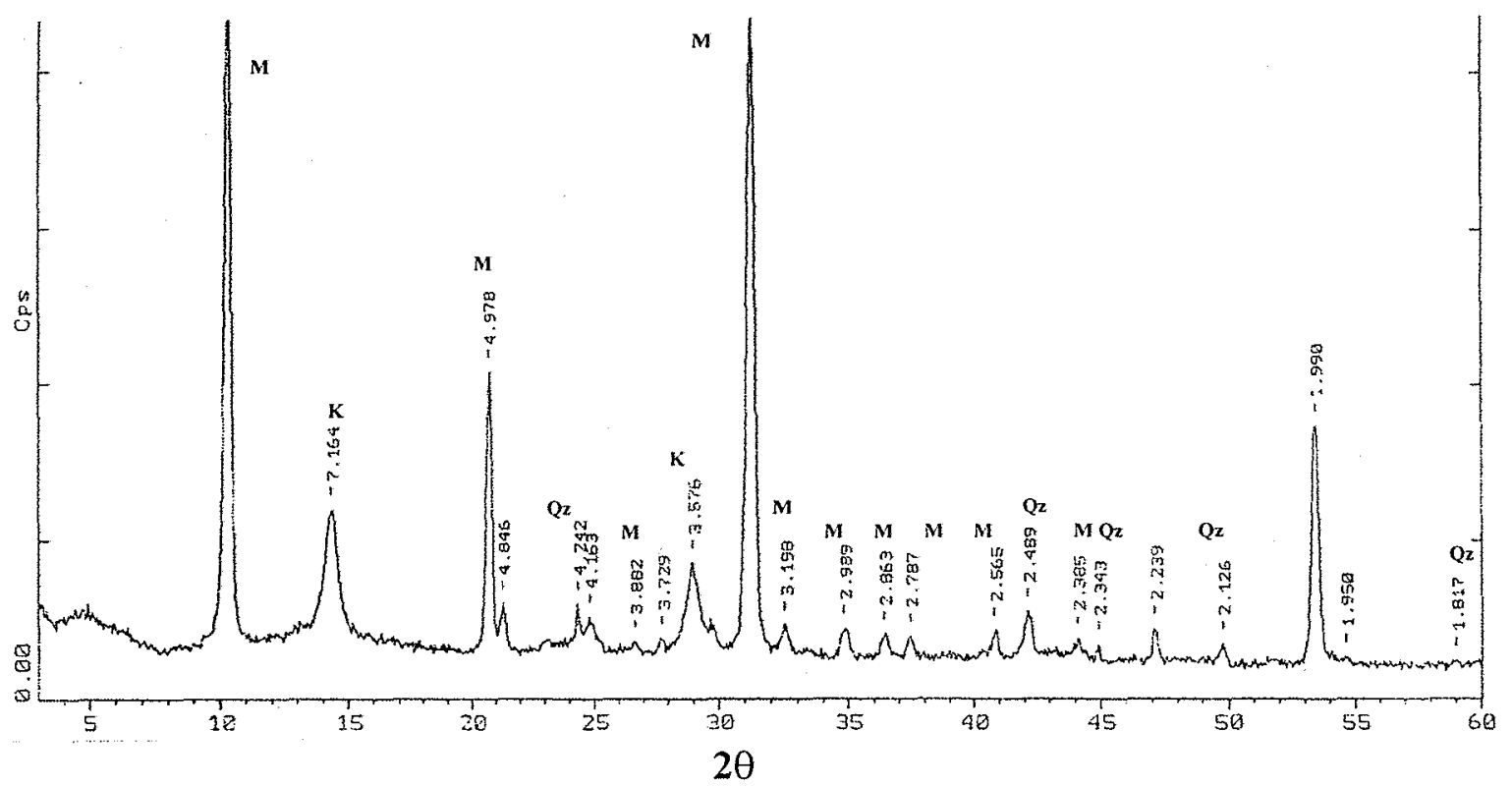

Figura 30 - Difratograma de raios-X da fração cascalhenta do horizonte subsuperficial do CXbd-2 (Qz = quartzo; $\mathrm{M}=$ mica; $\mathrm{K}=$ caulinita $)$

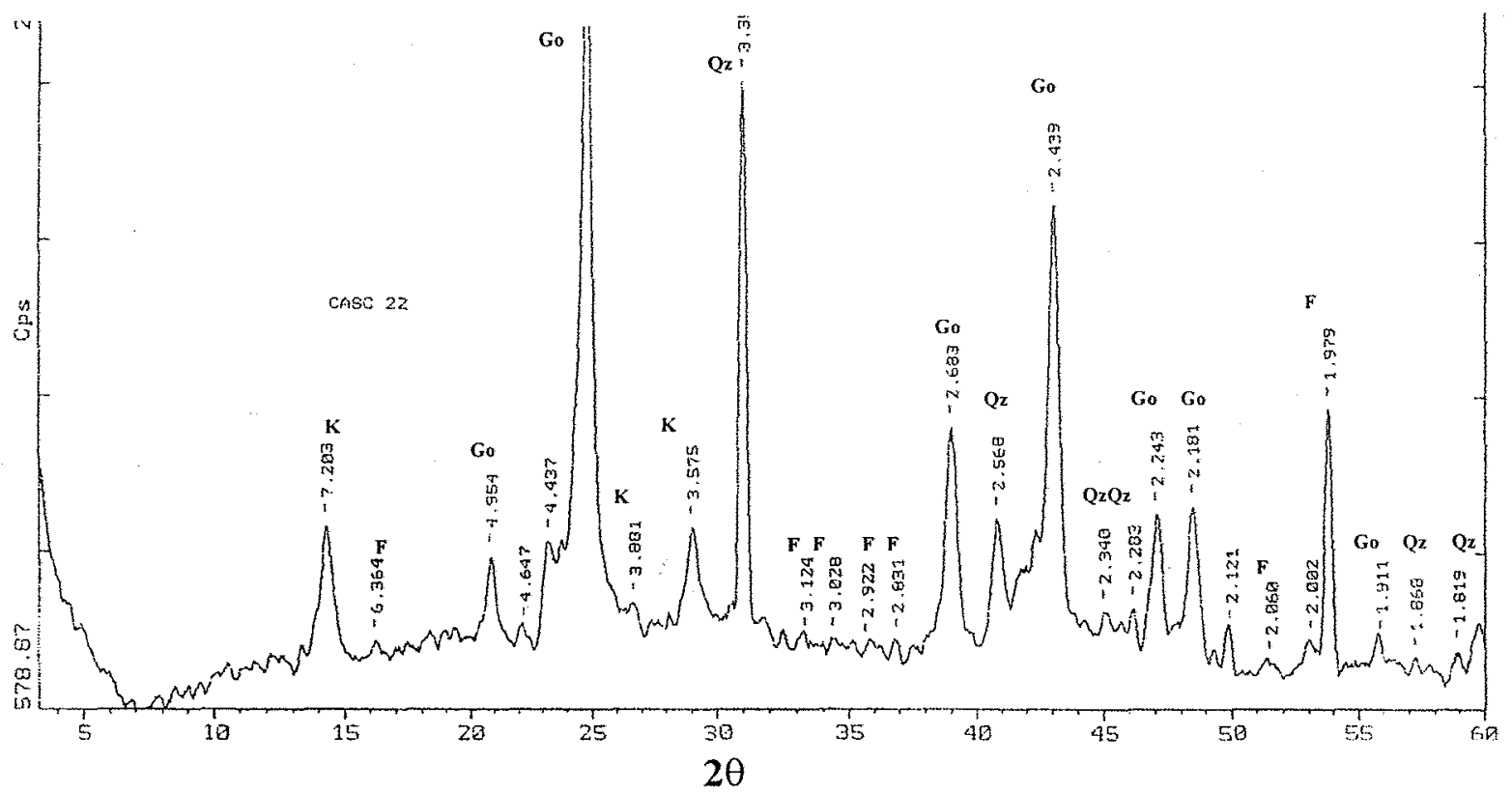

Figura 31 - Difratograma de raios-X da fração cascalhenta do horizonte subsuperficial do FXd $(\mathrm{Qz}=$ quartzo; $\mathrm{M}=$ mica; Go = goetita; $\mathrm{F}=$ feldspato $\mathrm{K}=$ caulinita $)$ 


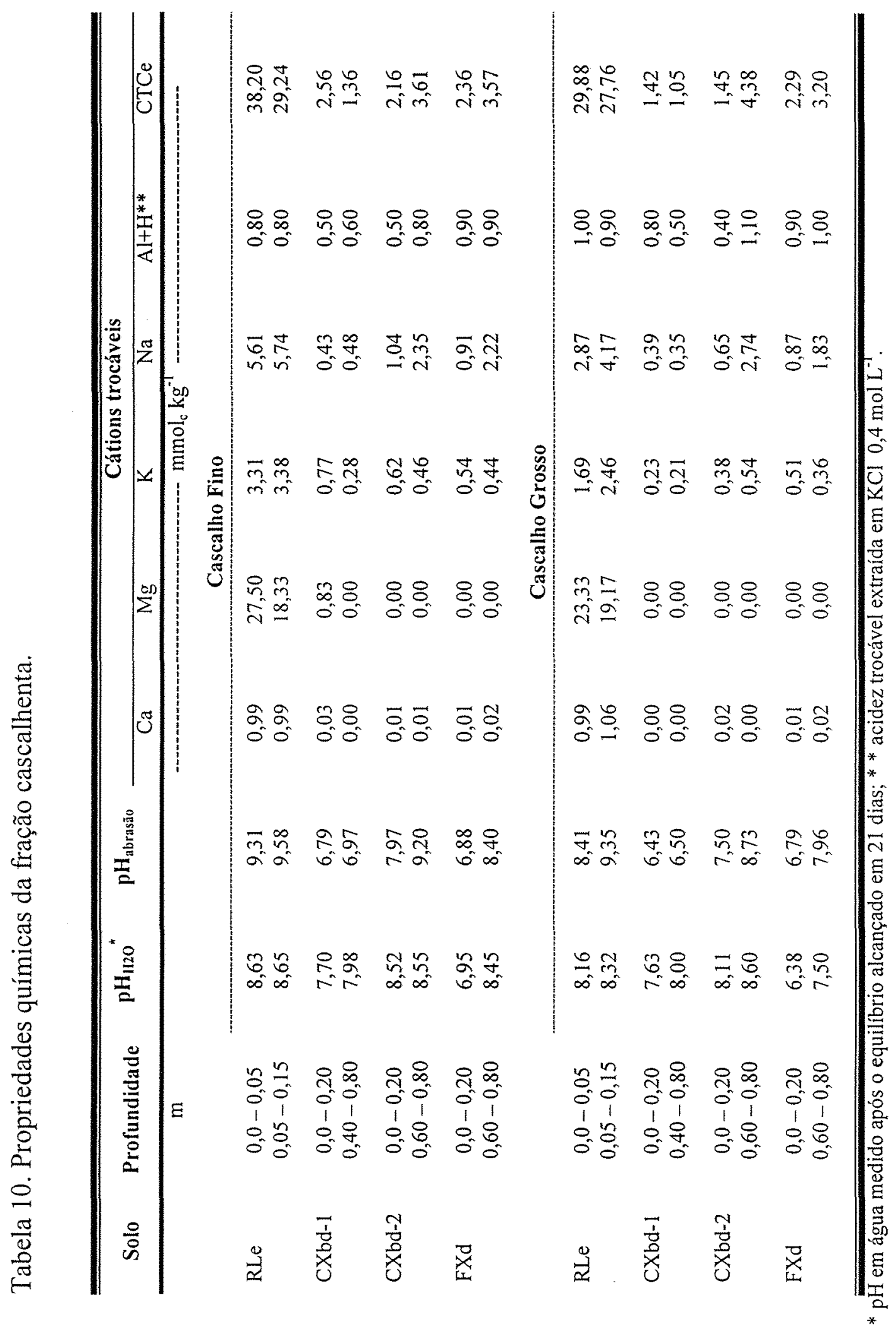


composição mineralógica dos fragmentos, principalmente os minerais micáceos, certamente contribuiu para a elevada CTC deste material.

Por meio de técnicas de microscopia eletrônica de varredura e confecção de lâminas delgadas, Martín-García et al. (1999) presumiram que, à medida que o processo de intemperização avança, a fábrica original do material de origem. que compõe os cascalhos, altera-se, aumentando a porosidade. Os autores detectaram o preenchimento do espaço poroso dos fragmentos de rocha por argila, óxidos de ferro e matéria orgânica, ou seja, partículas de natureza coloidal que podem influenciar na superestimativa da $\mathrm{CTC}_{\mathrm{e}}$.

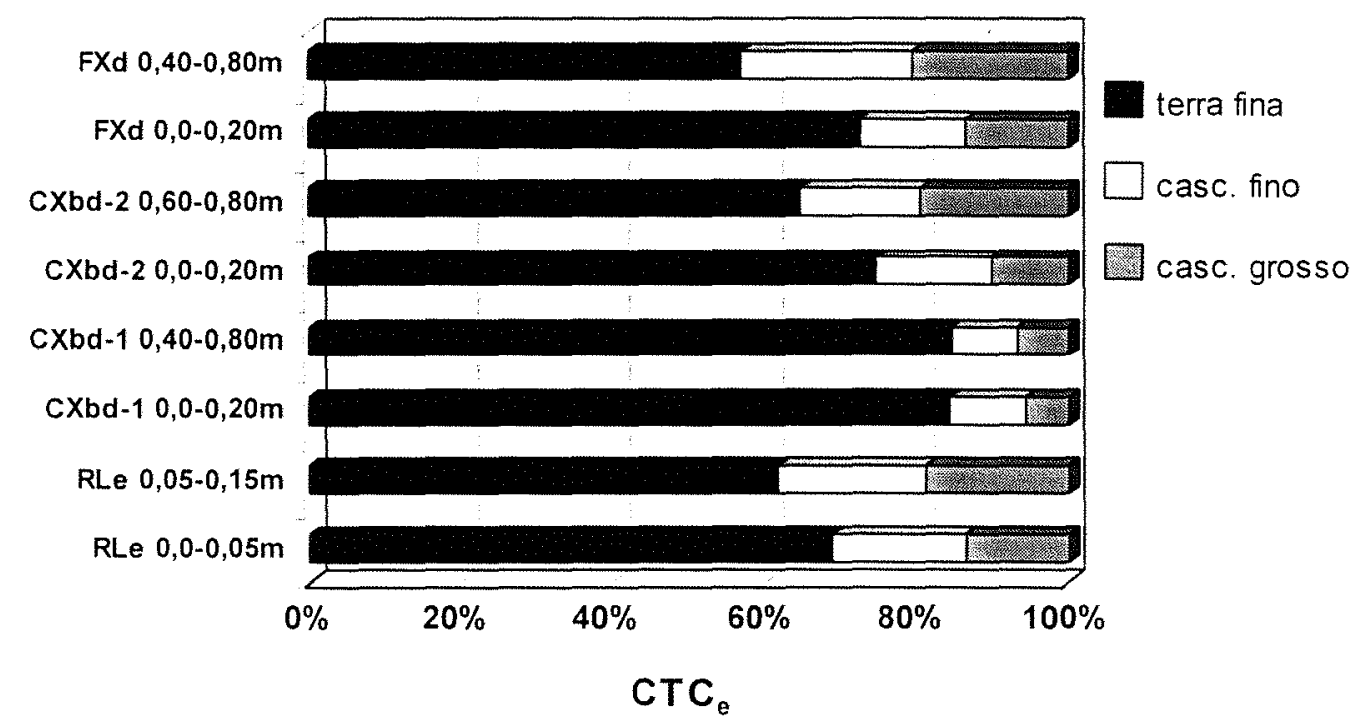

Figura 32. $\mathrm{CTC}_{\mathrm{e}}$ da fração cascalhenta em relação à $\mathrm{CTC}_{\mathrm{e}}$ total do solo.

As condições genéticas de formação do siltito, principalmente os da Formação Corumbataí, conferem alta porosidade ao material, por se tratar de rocha sedimentar (Suguio, 1998). Além disso, o material cimentante dos grãos de quartzo certamente é matéria orgânica ou carbonatos, aliados à hematita, característicos do Grupo Passa Dois.

Desconsiderando o teor natural de $\mathrm{C}$ orgânico e $\mathrm{N}$ que os fragmentos de rochas do RLe possam ter, quantidades consideráveis são acumuladas nos 
fragmentos de rocha durante o desenvolvimento do solo (Ugolini et al., 1996; Corti et al., 1997). Agnelli et al. (2000) atribuíram a presença de resíduos biológicos no ácido húmico dos fragmentos de rocha à ciclagem mais rápida de matéria orgânica dentro deste material, pois o ambiente no interior dos fragmentos pode ser favorável à transformação de materiais orgânicos em substâncias húmicas que, conseqüentemente, estarão envolvidas em processos químicos, incluindo aqueles relacionadas à atividade de superfície.

Os cascalhos finos e grossos dos CAMBISSOLOS foram pouco atuantes na $\mathrm{CTC}_{\mathrm{e}}$ do solo (Figura 32), apresentando uma contribuição média de $10 \%$. A baixa $\mathrm{CTC}_{\mathrm{e}}$ do CXbd-1 pode estar vinculada ao seu material de origem. Inicialmente sedimentares, com pouca cimentação, os pelitos sofreram metamorfismo intenso, processo que não atuou para o enriquecimento mineral do material. Já o CXbd-2, originado de micaxisto, possui minerais micáceos, que somente desempenham função de superfície em estádios mais avançados de intemperização. Nestas condições, o $\mathrm{K}^{+}$que permeia as lâminas do mineral não é liberado e, com isso, a carga gerada da substituição de $\mathrm{Si}^{+4}$ por $\mathrm{Al}^{+3}$ continua neutralizada (Porta et al., 1999). Outra possível explicação para a CTC baixa dos fragmentos de rocha é a formação de minerais ricos em $\mathrm{Al}$, típicos da região tropical, atuando no bloqueio dos sítios de troca (Ugolini et al., 1996). Mesmo não apresentando elevada CTC, a goetita e a caulinita presentes na composição das concreções do FXd podem estar contribuindo com sua superfície para a CTC dos cascalhos, que respondem, em média, por $60 \%$ da CTC total do solo.

A estabilização do pH, como previsto por Matín-García et al. (1999), se deu após vinte dias de imersão em água (Figura 33). Martín-García et al. (1999), estudando as propriedades dos cascalhos originados de quartzitos e micaxistos, verificaram que a acidificação foi maior nos cascalhos finos do que nos grossos, com aumento das camadas mais profundas para a superficiais. 
RLe, cascalho fino

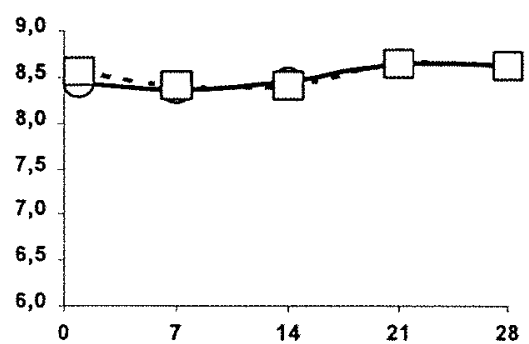

CXbd-1, cascalho fino

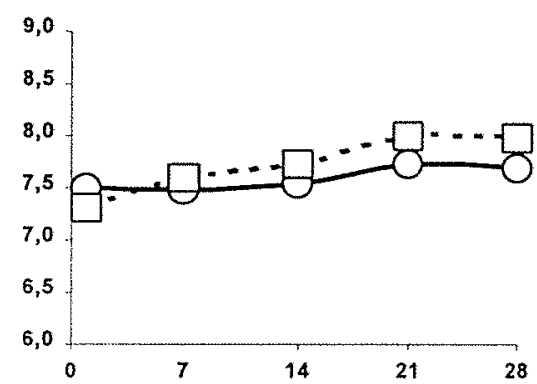

a

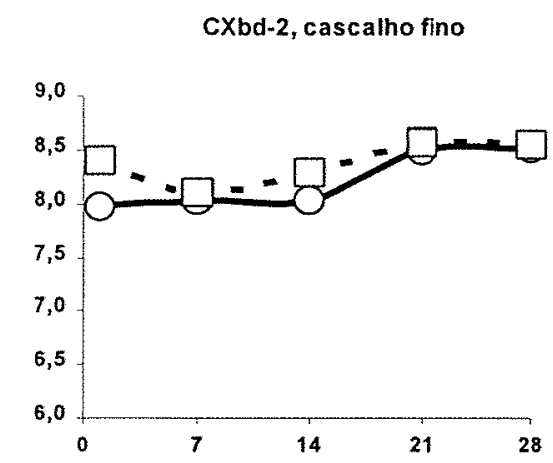

FXd, cascalho fino

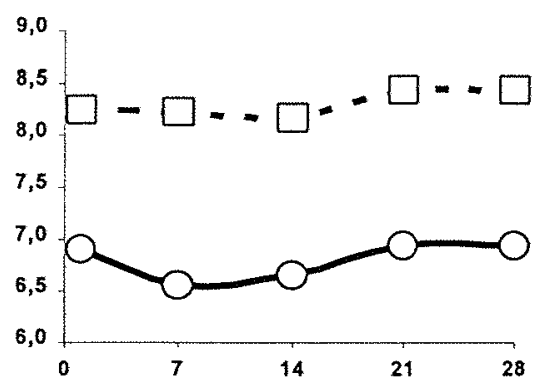

RLe, cascalho grosso

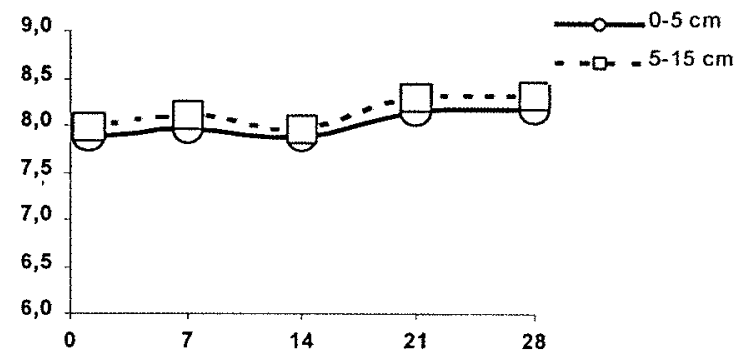

CXbd-1, cascalho grosso

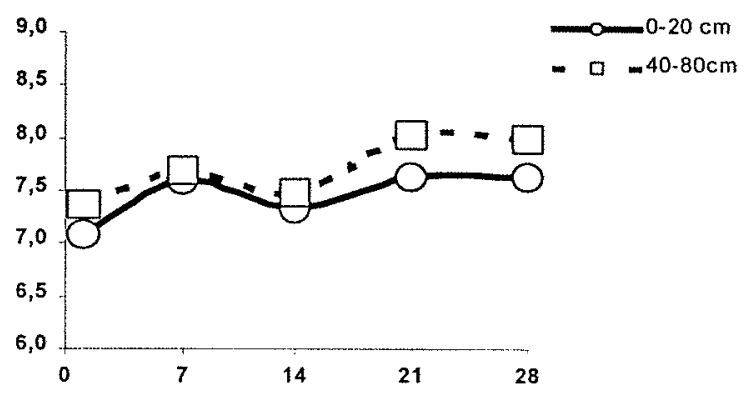

CXbd-2, cascalho grosso

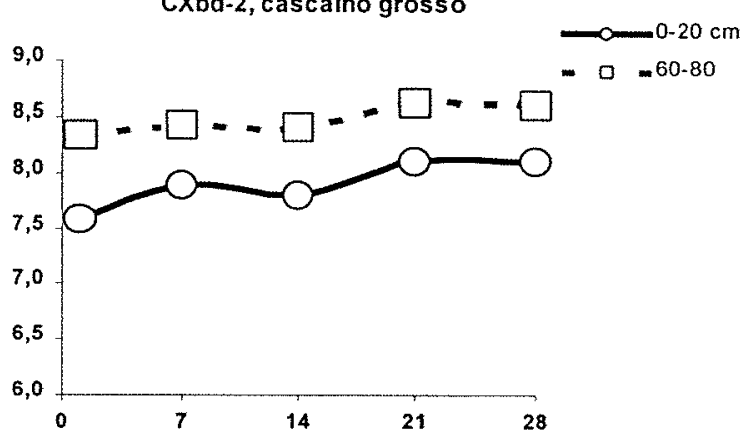

FXd, cascalho grosso

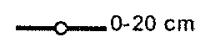

$=-0 .-60-80 \mathrm{~cm}$

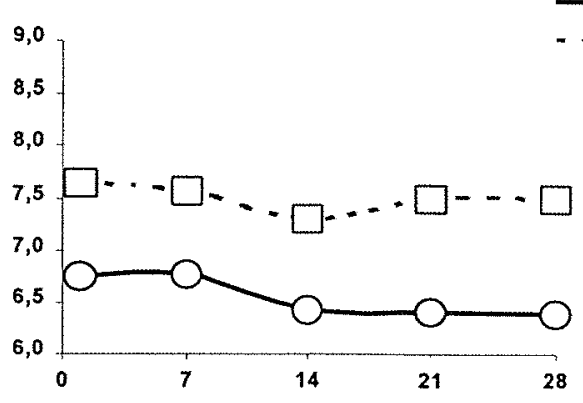

dias

Figura 33. Variação do pH dos cascalhos ao longo do tempo. 
Com exceção dos cascalhos grossos do $\mathrm{FXd}$, todos os materiais, independentemente do material de origem, elevaram o $\mathrm{pH}$ da solução a partir da segunda semana, até a estabilização em 28 dias.

\subsection{Terra fina}

\subsubsection{Correlações entre $\mathrm{CTC}_{\mathrm{e}}$ e alguns atributos dos solos}

A análise de regressão múltipla contemplou, conjuntamente, variáveis que foram significativas (15\%) quanto ao coeficiente de correlação (r) com a CTC do solo (Apêndice A1). O número de amostras foi relativamente pequeno para que extrapolações possam ser feitas, sendo prudente reservar qualquer inferência ao conjunto de solos empregado neste estudo.

A matéria orgânica, juntamente com a CTC das frações mais grossas, especialmente silte e grande parte das subfrações de areia, apresentaram menor dispersão dos resultados e coeficientes de correlação com alto nível de significância $(0,1 \%)$ (Apêndice $A 1)$, gerando a seguinte equação $\left(R^{2}=0,85\right)$ :

\section{CTC $_{\text {SOLO }}=-2,20+85,48$ CTC $_{\text {AREIA MUITO FINA }}+$ 0,70 Matéria orgânica}

A CTC do solo não apresentou correlação significativa com a CTC da argila, embora se encontre na literatura que a argila, em função de sua alta superfície específica, é responsavel por grande porção da CTC do solo. A maioria dos solos possui textura argilosa a muito argilosa (Tabela 7) e, mesmo assim, a CTC não foi elevada, principalmente para os LATOSSOLOS e CAMBISSOLOS. Tal fato pode estar condicionado à reatividade destas partículas. Óxidos de ferro $\mathrm{e}$ alumínio, colóides com grande representatividade nos solos intemperizados dos 
trópicos, são incluídos na fração argila, mas não são argilominerais atuantes na CTC (Tessens \& Shamshuddin, 1982; Churchman, 2000; Goldberg et al., 2000).

A influência dos óxidos de ferro e matéria orgânica ficou evidente pela comparação dos resultados da CTC do solo e da CTC mineral, composta pela soma da CTC de cada fração por massa de terra fina (Tabela 11). Referências bibliográficas são contraditórias a respeito da CTC dos óxidos de ferro. Vários autores, mencionados por Raij (1967) destacaram a atuação dos óxidos de $\mathrm{Fe}$ e $\mathrm{Al}$ na fração coloidal do solo por apresentarem CTC da ordem de $40 \mathrm{mmol}_{\mathrm{c}} \mathrm{kg}^{-1}$, apesar de admitirem ausência desta propriedade em $\mathrm{pHs}$ próximos da neutralidade.

Fieldes et al. (1952) atribuíram a alta CTC de alguns solos lateríticos ao elevado teor de óxidos hidratados amorfos de ferro, alumínio e titânio. Entretanto, posições de troca da caulinita, mineral de argila de grande expressividade em solos tropicais, podem ter suas cargas negativas bloqueadas por colóides oxídicos. Desta forma, a remoção dos óxidos de ferro pode resultar em aumento da CTC, como foi verificado, principalmente para os LATOSSOLOS em subsuperfície (Figura 34).

De acordo com Yu (1997), a carga positiva dos óxidos pode compensar as cargas negativas de superfície e podem ainda exercer efeito físico de mascaramento da superfície negativa. $\mathrm{O}$ incremento da superfície negativa após a remoção dos óxidos de ferro pode ser atribuída à liberação de cargas negativas como resultado da eliminação dos dois fatores mencionados. $\mathrm{O}$ decréscimo da carga positiva é equivalente à quantidade de carga positiva eliminada juntamente com os óxidos de ferro. Já a diferença entre o aumento da carga negativa e o decréscimo da carga positiva após a remoção dos óxidos de ferro pode ser relacionada ao efeito físico sobre a superfície negativa. 


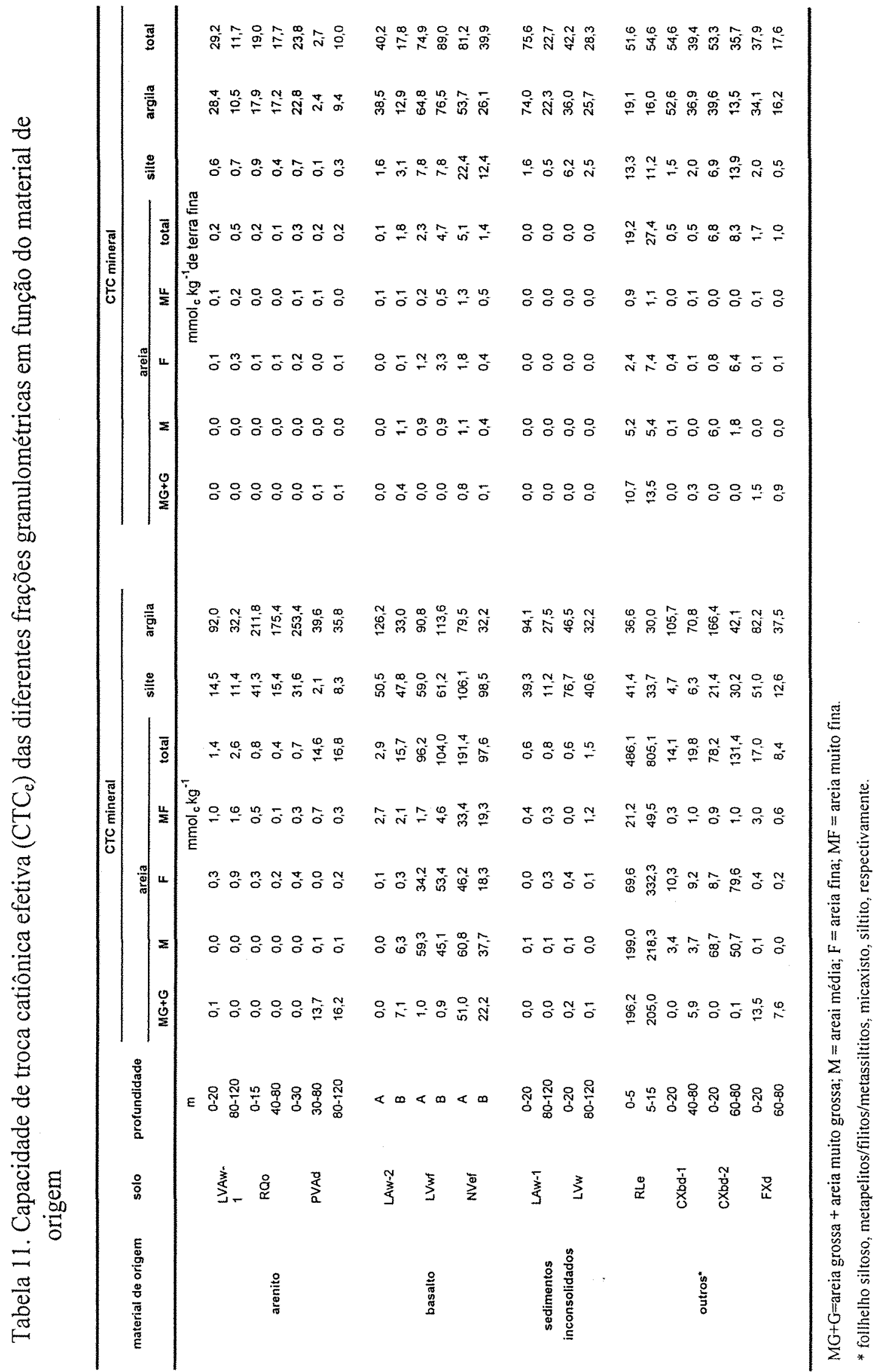


Em superfície, nota-se maior contribuição da matéria orgânica para a CTC que, em termos de quantidade absoluta, pode ser bem menor do que a carga constante do solo (Figura 34).
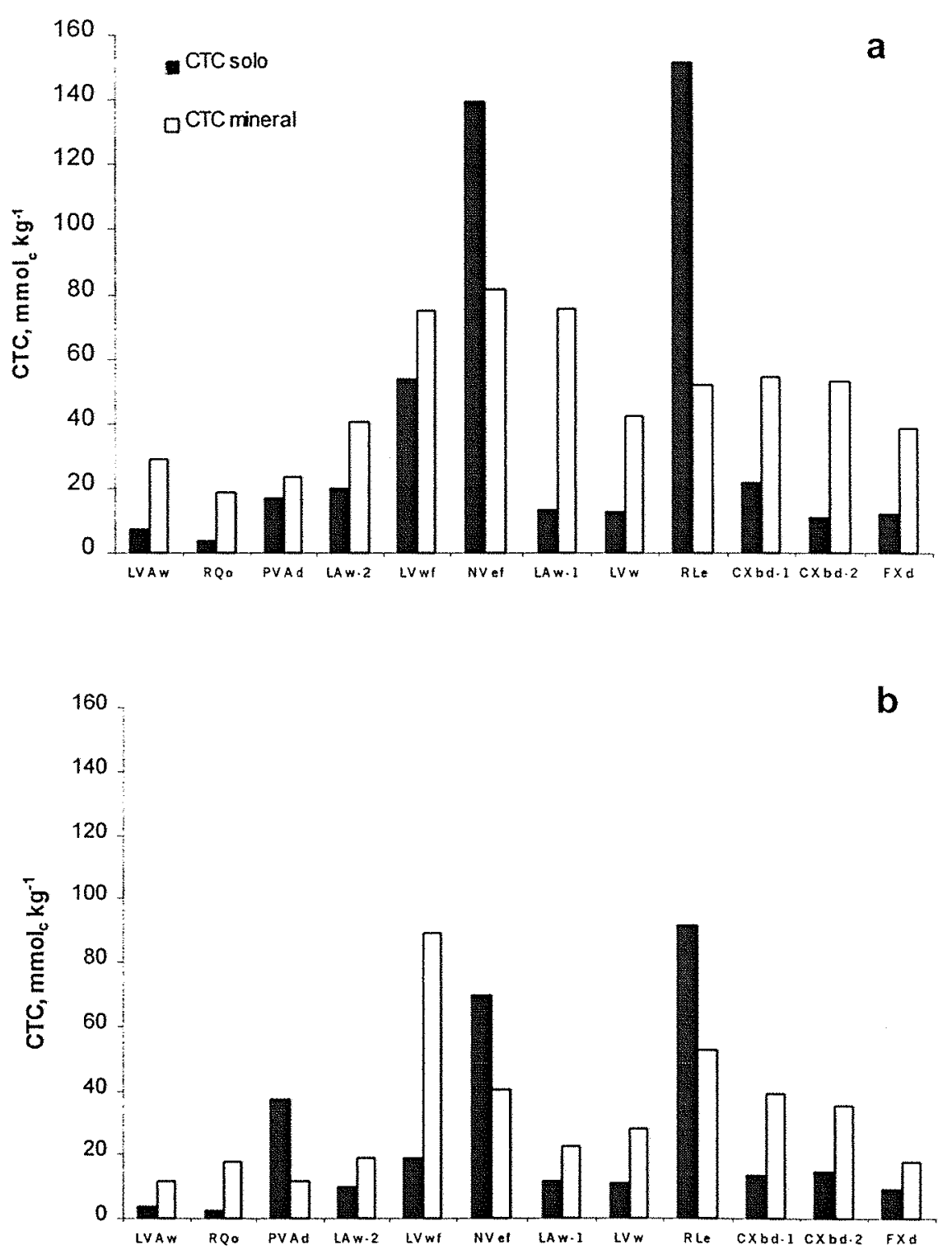

Figura 34. $\mathrm{CTC}_{\mathrm{e}}$ mineral e CTC total do solo, em superfície (a) e em profundidade (b). 
Assim, a contribuição efetiva do húmus para a CTC é relativa, porque os minerais destes solos estão quase desprovidos deste tipo de carga. Outra hipótese é que colóides orgânicos, carregados negativamente, podem se combinar com óxidos de $\mathrm{Fe}$ e $\mathrm{Al}$ positivamente carregados ou com sitios positivos de arestas quebradas de minerais de argila (Yu, 1997). Verdade (1956) apontou influência negativa da fração orgânica ao inibir a CTC da fração mineral. Mesmo concluindo que a matéria orgânica representou 30 a $40 \%$ do valor total da CTC em solos argilosos e 50 a $60 \%$ em solos arenosos, Bartlett et al. (1936) verificaram considerável variação na influência da remoção da matéria orgânica na capacidade total de troca.

A CTC mineral é interpretada como uma função da mineralogia dos solos Turpault et al.,1996). Raij (1967) verificou relação entre a CTC de solos originados de rochas ácidas e básicas, obtendo CTC da argila de solos oriundos de rochas básicas variando de 91 a $130 \mathrm{mmol}_{\mathrm{c}} \mathrm{kg}^{-1} \mathrm{e}$ de solos de rochas ácidas de 27 a $78 \mathrm{mmol}_{\mathrm{c}} \mathrm{kg}^{-1}$. Alta CTC de solos herdados de argilito da Fm Corumbataí também foi encontrada por Raij (1967), a exemplo do RLe desenvolvido sobre a mesma Formação.

Durante as reações de intemperismo, a capacidade de troca é desenvolvida pela transformação dos minerais primários do solo. Essas reações são geralmente mais marcantes nas frações finas, onde a superfície reativa é maior. Porém, no caso dos minerais facilmente intemperizáveis (como a biotita, clorita e anortita), estas reações podem ocorrer nas frações grosseiras (Fanning et al., 1989). Os íons $\mathrm{H}^{+}$, significativamente presentes em condições ácidas como a dos trópicos, podem desempenhar importante função na quebra dos feldspatos. Seu pequeno tamanho permite sua entrada na estrutura do cristal e sua alta relação carga/raio pode afetar o balanço de carga dentro da estrutura. A remoção de cátions da estrutura leva à instabilidade da estrutura do mineral e, conseqüentemente à geração de cargas (Huang, 1989). 
A CTC das micas é pequena quando comparada com minerais $2: 1$ como esmectita e vermiculita, devido aos cátions entrecamadas destes minerais serem trocáveis e o das micas não. A superfície das micas é restrita à contribuição externa. Em certas condições, os cátions entrecamadas da mica desidratada (usualmente $\mathrm{K}$ ) podem ser trocados por cátions hidratados e, após a troca, a mica torna-se um mineral expandido (vermiculita ou smectita) do tipo 2:1 de alta CTC (Sawhney, 1989).

Assim, a contribuição da areia fina para a CTC dos solos pode estar associada à sua mineralogia, decorrente do material de origem. Analisando resultados de CTC da areia fina entre os solos, de acordo com o material de origem, nota-se que as areias de maior reatividade estão associadas à materiais que supostamente contribuem para este atributo, como o basalto, siltito e micaxisto. Micas e argilominerais mais reativos, de grade $2: 1$, tais como ilita, vermiculita, esmectita e vermiculita com hidróxidos entre camadas (VHE) são, geralmente, constituintes com menor expressão em solos tropicais. Entretanto, em Latossolos derivados de rochas ácidas, como micaxisto e arenito, estes minerais podem predominar (Fanning et al., 1989; Churchman, 2000).

Os minerais micáceos possuem arranjo cristalino do tipo 2:1. Uma das quatro posições tetraedrais normalmente contém $\mathrm{Al}^{+3}$ em lugar de $\mathrm{Si}^{+4}$, o que resulta em excesso de carga negativa que é balanceada por cátions monovalentes, notadamente o $\mathrm{K}^{+}$(Olson et al., 2000). Logo, as sedes de troca ficam bloqueadas e a CTC reduzida. As argilas micáceas podem proceder das micas presentes de materiais originados tanto de rochas ígneas, quanto de metamórficas (xistos) e podem apresentar CTC da ordem de 100 a $400 \mathrm{mmol}_{\mathrm{c}} \mathrm{kg}^{-1}$. O valor de ki pode explicar a baixa atividade da argila do CXbd-2. Na fração argila, micas são pobremente cristalinas e possuem baixos conteúdos de $\mathrm{K}^{+}$(Olson et al., 2000). As micas de granulação mais fina liberam seu potássio mais lentamente do que as de granulação mais grosseira. Os valores de CTC variaram de 0,1 a $79 \mathrm{mmol}_{\mathrm{c}} \mathrm{kg}^{-1}$ 
entre as diversas subfrações e $131,4 \mathrm{mmol}_{\mathrm{c}} \mathrm{kg}^{-1}$ para a fração areia total em subsuperfície para o CXbd-2 e são fortes indicativos de que a argila pode reter K, enquanto que cargas negativas estão sendo geradas nos grãos maiores pela sua liberação (Porta et al., 1999). Embora não haja teores adequados de $\mathrm{K}$ para a nutrição vegetal (Tabela 5), seja pelo seu aprisionamento sob a forma não trocável, seja pela intensa lixiviação após sua liberação, a presença de potássio, assim como de ilita, na mineralogia deste solo é presumida não somente pelo seu material de origem, mas também pelo alto valor de $\mathrm{pH}$ de abrasão em ambos os horizontes (Tabela 8). A incorporação de potássio via fertilizantes em solos desta natureza pode resultar em redução de suas cargas negativas. O mesmo ocorre com o emprego de fertilizantes amoniacais, pois o íon $\mathrm{NH}_{4}^{+}$, de raio iônico semelhante ao do potássio, pode ser fixado em posição interlaminar. Variações na composição e no comportamento podem ser explicadas pela presença de interestratificados, quando o intemperismo é atuante. A fração areia dos solos originados de basalto possivelmente contenham plagioclásios cálcicos e, pelo mesmo mecanismo descrito para as micas, podem ser geradas cargas negativas que atuam até a intemperização do feldspato para argila.

\subsubsection{Correlações entre CTA e alguns atributos dos solos}

A saturação por alumínio, bem como seu teor extraível pelo ataque sulfúrico, juntamente com a matéria orgânica e a contribuição da areia grossa na textura do solo, foram as variáveis que, com nível de significância de $15 \%$, compuseram a equação que estima a CTA para os solos estudados $\left(\mathrm{R}^{2}=0,56\right)$ (Apêndice A2) :

$\mathrm{CTA}_{\text {SOLO }}=6,86+0,05 \mathrm{Al}_{2} \mathrm{O}_{3}-0,06 \mathrm{~m} \%-0,18$ matéria orgânica $+0,79$ areia grossa \% 
Nos trópicos o $\mathrm{Al}$ tende a substituir o $\mathrm{Fe}$ nos minerais oxídicos, diminuindo a cristalinidade e o tamanho das partículas, levando ao aumento significativo da superfície específica (Pardo \& Guadalix, 1990; Ranst et al., 1998), atributo físico de grande influência nas reações de superfície.

Muitos ânions podem interferir na cristalização do $\mathrm{Al}(\mathrm{OH})_{3}$. O mecanismo básico de interferência é atribuído à competição de ânions com $\mathrm{OH}^{-}$e $\mathrm{Al}^{+3}$. Em todos os hidróxidos de alumínio conhecidos, grande quantidade da superfície $\mathrm{OH}^{-}$ ou $\mathrm{O}^{-2}$ está ligada com íons $\mathrm{Al}^{+3}$, similar a estrutura interior de um cristal, e portanto, inativa. Somente o $\mathrm{OH}^{-}$da superfície quebrada que é ligado a um Al é reativo. A superficie reativa $\mathrm{Al}-\mathrm{OH}$ adsorve $\mathrm{H}^{+}$ou $\mathrm{OH}^{-}$para desenvolver superfície de carga, mas nem toda a a superfície dos grupos $\mathrm{OH}$ adsorvem $\mathrm{H}$ ou $\mathrm{OH}$ ao mesmo $\mathrm{pH}$. Comportam-se como eletrólitos polivalentes fracos. Vários autores sugerem três tipos de adsorção aniônica:

1. adsorção não específica: alguns ânions como $\mathrm{NO}_{3}{ }^{-}, \mathrm{ClO}_{4}{ }^{-}$e $\mathrm{Cl}^{-}$podem ser adsorvidos somente por superfícies carregadas positivamente;

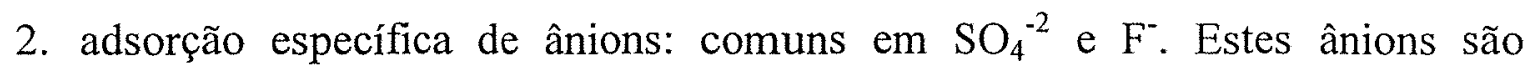
quimicamente adsorvidos somente no lado ácido do PCZ;

3. adsorção específica de ânions de ácidos completamente dissociados, como fosfatos e silicatos, que ocorre no lado negativo do $\mathrm{PCZ}$ envolvendo reações com $\mathrm{OH}^{-}$.

A remoção de óxidos de ferro expõe mais grupos Al-OH da caulinita e da gibsita, levando segundo ao aumento do ponto de carga zero (Ranst et al., 1998). Ranst et al. (1998) verificaram, em solos com carga variável, redução da CTA em $43 \%$ após a deferrificação das amostras. Dessa forma, pode-se presumir que a CTA é inibida pela matéria orgânica, pois em amostras superficiais deferrificadas e isentas de matéria orgânica a $\mathrm{CTA}_{\mathrm{e}}$ é maior do que a amostra completa (Figura $35)$. 

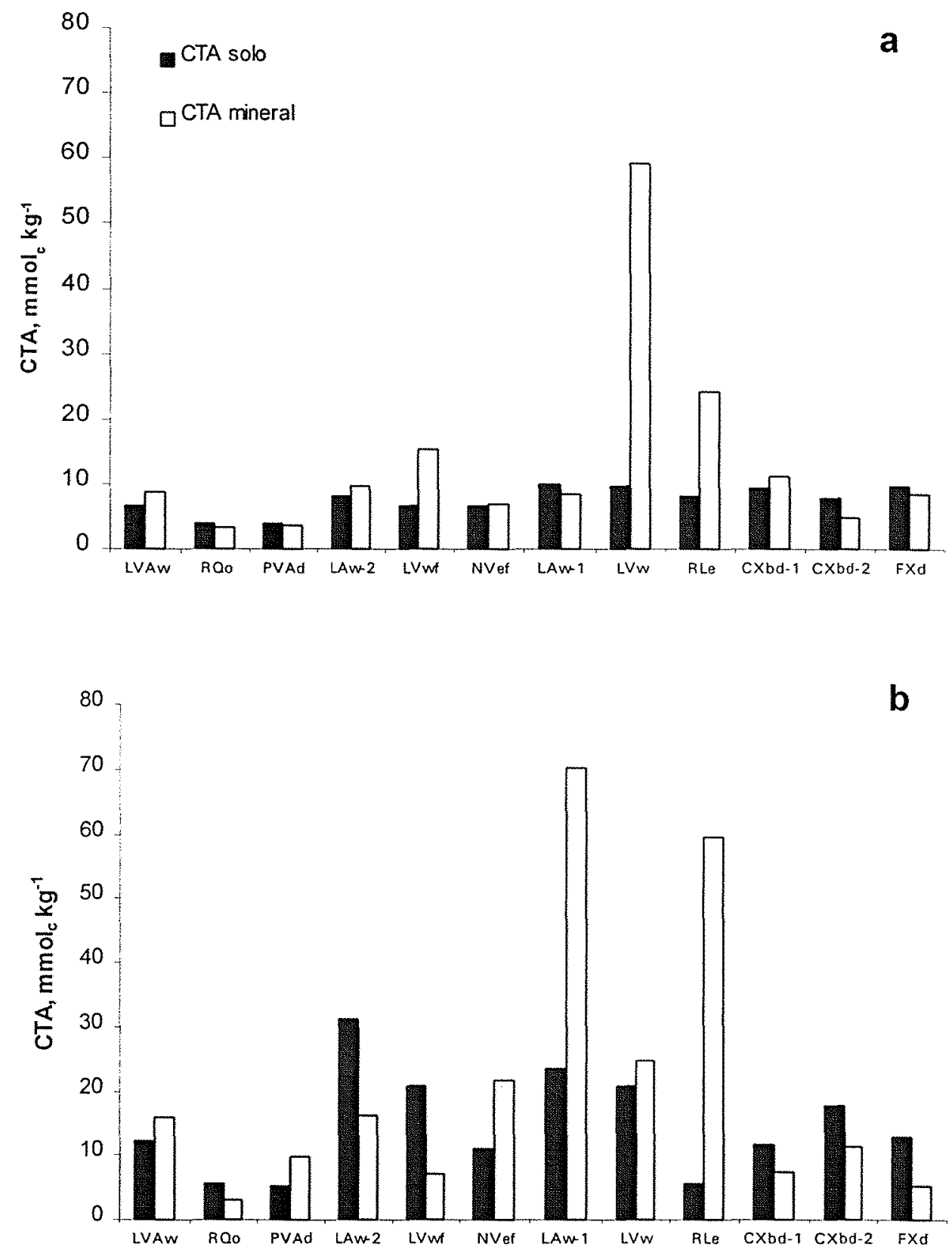

Figura 35 - CTA $A_{e}$ mineral e CTA total do solo, em superfície (a) e em profundidade (b). 
A CTA da caulinita é pequena, mas atribuível à cargas positivas que se desenvolvem em sítios das bordas dos cristais onde o oxigênio aceita um próton sob condições ácidas $(\mathrm{pH}<\mathrm{PCZ})$. Dependendo do $\mathrm{pH}$, alguma CTA pode ser atribuída ao $\mathrm{Al}^{+3}$ adsorvido à superfície da caulinita (Olson et al., 2000). O decréscimo na quantidade de carga líquida negativa de superfície a $\mathrm{pH}$ maior do que o PCZ, após a remoção da matéria orgânica, é causado principalmente pelo aumento na carga positiva, mais do que no decréscimo da carga negativa. A CTA foi maior em subsuperficie, cujo balanço de carga foi positivo, sendo talvez devida à ausência de matéria orgânica (Tabela 12). Vários dos solos estudados, principalmente os LATOSSOLOS, apresentaram boa concordância entre $\triangle \mathrm{pH}$ e a diferença entre a $\mathrm{CTC}_{e}$ e CTA $\mathrm{C}_{\mathrm{e}}$ determinadas.

A CTA das micas é pequena e restrita a superficies quebradas, onde as cargas positivas podem se desenvolver a baixos pHs por protonação de íons $\mathrm{O} e$ $\mathrm{OH}$. Quando uma CTA significativa ocorre, ela é atribuída ao recobrimento por óxidos de Fe. Esmectitas normalmente possuem CTA $<50 \mathrm{mmol}_{\mathrm{c}} \mathrm{kg}^{-1}$, devido à ânions, de tamanhos apropriados, deslocarem as hidroxilas estruturais somente das bordas dos cristais da smectita.

Em solos com elétrica variável, os óxidos de ferro são os principais materiais na produção de carga positiva de superfície e isto se deve aos grupos funcionais $\mathrm{Fe}-\mathrm{OH}$ da sua superficie que podem adsorver íons $\mathrm{H}^{+}$da solução quando o pH é menor do que seu PCZ . 


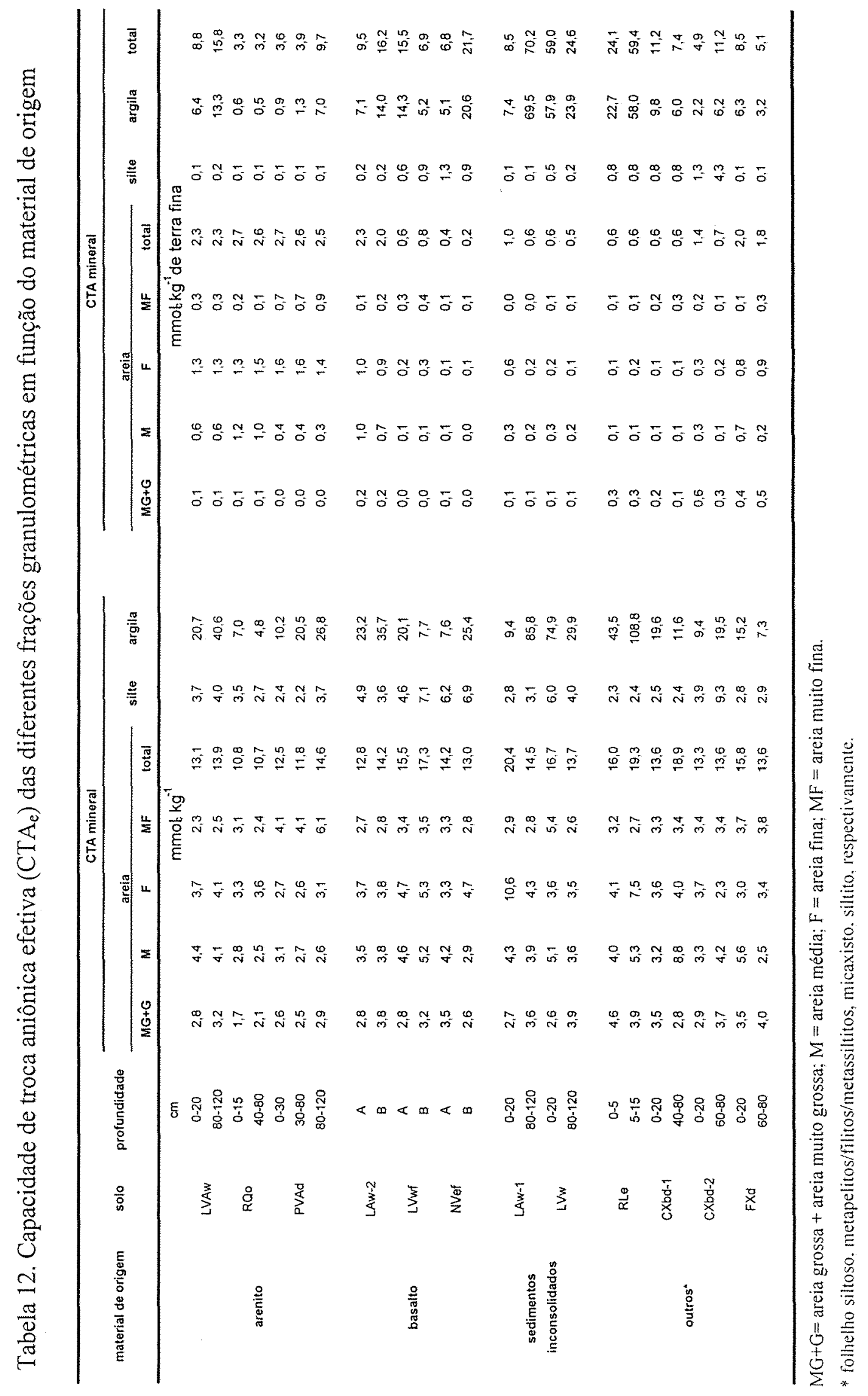




\section{CONCLUSÕES}

- $\mathrm{A} \mathrm{CTC}_{\mathrm{e}}$ dos solos estudados foi dependente da matéria orgânica e da $\mathrm{CTC}_{\mathrm{e}}$ da areia muito fina;

- $\mathrm{A} \mathrm{CTA}_{\mathrm{e}}$ dos solos estudados foi dependente dos óxidos de alumínio;

- As frações grosseiras da terra fina e os cascalhos (>2 mm) desempenham importantes funções químicas no solo, sendo função da litologia (material de origem);

- O pH de abrasão não foi um índice adequado para estimar o estádio de intemperização e a fertilidade potencial dos solos estudados. 


\section{REFERÊNCIAS BIBLIOGRÁFICAS}

AGNELLI, A.; CELI, L.; DEGL'INNOCENTI, A.; CORTI, G.; UGOLINI, F.C. Chemical and spectroscopic characterization of the humic substances from sandstone-derived rock fragments. Soil Science, v.165, n.4, p.314-327, 2000.

ALEXANDER, E.B. Volume estimates of coarse fragments in soils: A combination of visual and weighing procedures. Journal of Soil and Water Conservation, v.37, p.62-63, 1982.

ALLEONI, L.R.F. Atributos eletroquímicos de solos ácricos do Norte paulista. Piracicaba, 1992. 123p. Dissertação (Mestrado) - Escola Superior de Agricultura "Luiz de Queiroz", Universidade de São Paulo.

ALLEONI, L.R.F.; CAMARGO, O.A. Atributos físicos de latossolos ácricos do Norte paulista. Scientia Agricola, v.51, n.2, p.321-326, 1994a.

ALLEONI, L.R.F.; CAMARGO, O.A. Pontos de efeito salino nulo de latossolos ácricos. Revista Brasileira de Ciência do Solo, v.18, n.2, p.175-180, 1994 b. 
ANDERSON, J.U. An improved pretreatment for mineralogical analysis of samples containing organic matter. Clays and Clay Minerals, v.10, p.380$388,1961$.

BABALOLA, O; LAL, R. Subsoil gravel horizon and maize root growth I. Gravel concentration and bulk density effects. Plant and Soil, v.46, p.337346, 1977.

BACCARO, C.A.D. Unidades geomórficas do Triângulo Mineiro. Sociedade e Natureza, v.3, n.5, p.37-42, 1991.

BALDOCK, J.A.; NELSON, P.N. Soil organic matter. In: SUMNER, M.E (Ed.). Handbook of soil science. Boca raton: CRC Press, 2000. cap.2, p.B25-120.

BARROW, N.J. Reaction of anions and cations with variable charge soils. Advances in Agronomy, v.38, p.183-230, 1985.

BARTLETT, J.B.; RUBLE, R.W.; THOMAS, R.P. The influence of hydrogen peroxide treatments on the exchange capacity of Maryland soils. Soil Science, v.44, n.2, p.123-138, Nov. 1936.

BIRKELAND, P.W. Pedology, weathering, and geomorphological research. New York: Oxford University Press, 1974. 285p.

BOHN, H.L.; McNEAL, B.L.; O'CONNOR, G.A. Soil chemistry. New York: John Wiley, 1979. 329p. 
BOURGET, S.J.; TANNER, C.B. Removal of organic matter with sodium hypobromite for particle-size analysis of soils. Canadian Journal of Agricultural Science, v.33, p.579-585, 1953.

BRADY, N.C. Natureza e propriedades dos solos. 7.ed. New York: Livraria Freitas Bastos, 1989. 878p.

BRASIL. Ministério das Minas e Energia. Departamento Nacional da Produção Mineral. Projeto RADAMBRASIL: folha SF. 22 Lagoa Mirim: geologia, geomorfologia, vegetação, uso potencial da terra. Rio de Janeiro, 1986. (Levantamento de Recursos Naturais).

CAMARGO, O.A.; MONIZ, A.C.; JORGE, J.A.; VALADARES, J.M.A.S. Métodos de análise química, mineralógica e física de solos do Instituto Agronômico de Campinas. Campinas: IAC, 1986. 94p. (IAC. Boletim Técnico, 106).

CHILDS, S.W.; FLINT, A.L. Physical properties of forest soil containing rock fragments. Catena, v. 23, p.1-28, 1994.

CHURCHMAN, G.J. The alteration and formation of soil minerals by weathering. In: SUMNER, M.E (Ed.). Handbook of soil science. Boca Raton: CRC Press, 2000. cap.1, p.F-3-76.

COILE, T.S. Moisture content of small stones in soil. Soil Science, v.75, p.203207, 1953. 
CORTI, G.; AGNELLI, A.; UGOLINI, F.C. Release of Al by hidroxyinterlayered vermiculite and hidroxy-interlayered smectite during determination of cation exchange capacity in fine earth and rock fragments. European Journal of Soil Science, v.48, p.249-262, 1997.

CORTI, G.; UGOLINI, F.C.; AGNELLI, A. Classing the soil skeleton (greater than two milimeters): Proposed approach and procedure. Soil Science Society of America Journal, v.62, p.1620-1629, 1998.

DANIELS, R. The identification of plinthite. Soil Taxonomy News, n.4, p.14, 1982.

DION, H.G. Iron oxide removal from clays and its influence on base-exchange properties and X-ray diffraction patterns of clays. Soil Science, v.58, p.412$423,1944$.

DORRONSORO, C. Aporte de la fracción arena gruesa al conocimiento de la genesis del solo. Anales de Edafologia Agrobiologia, v.47, n.1/2, p.87-110, 1988.

DORRONSORO, C.; ARCO ORTIZ de ZARALE, J. del; ALONSO ROJO, P. Mineral weathearing indices of coarse sand fractions of soils. Anales de Edafologia Agrobiologia, v.47, n.1/2, p.11-134,1988.

DROSDOFF, M.; MILES, E.F. Action of hydrogen peroxide on weathered mica. Soil Science, v.46, p.391-395, 1938. 
EBERT, H. A estrutura pré-cambriana do sudoeste de Minas Gerais e áreas adjacentes. Boletim Paranaense de Geociências, v.26, p.42-45, 1967.

EMPRESA BRASILEIRA DE PESQUISA AGROPECUÁRIA - Centro Nacional de Pesquisa de Solos. Manual de métodos de análise de solo. 2.ed. Rio de Janeiro, 1997. 212p.

EMPRESA BRASILEIRA DE PESQUISA AGROPECUÁRIA - Centro Nacional de Pesquisa de Solos. Sistema Brasileiro de Classificação de Solos. Brasília: Embrapa, 1999.412p.

ESTADOS UNIDOS. Department of Agriculture. Soil Survey Division. Soil Conservation Service. Soil Survey Staff. Soil taxonomy: a basic system of soil classification for making and interpreting soil surveys. Washington, 1975. 754p. (USDA. Agriculture Handbook, 436).

FANNING, D.S.; KERAMIDAS, V.Z.; EL-DESOKY, M.A. Micas. In: DIXON, J.B.; WEED, S.B (Ed.) Mineral in soil environments. 2.ed. Madison : SSSA, 1989. cap.12, p552-624.

FARMER, V.C.; MITCHELL, B.D. Occurence of oxalates in soil clay following hydrogen peroxide treatment. Soil Science, v.96, n.4, p.221-229, 1963.

FERRARI, G.A.; MAGALDI, D. Degree of soil weathearing as determined by $\mathrm{pH}$ abrasion: aplications in soil study and paleopedology. Pedologié, v.33, n.2, p.93-104, 1983. 
FIELDES, M.; SWINDALE, L.D.; RICHARDSON, J.P. Relation of colloidal hydrous oxides to the high cation exchange capacity of some tropical soils of the Cook Islands. Soil Science, v.74, p.197-203, 1952.

GHABRU, S.K; ARNAUD, R.J.; MERMUT, A.R. Association of DCB extractable iron with minerals in coarse soil clays. Soil Science, v.149, n.2, p.112-120, 1990.

GILLMAN, G.P. A proposed method for the measurement of exchange properties of highly weathered soils. Australian Journal of Soil Research, v.17, p.129-139, 1979.

GILLMAN, G.P.; SUMPTER, E.A. Modification to the compulsive exchange method for measuring exchange characteristics of soils. Australian Journal of Soil Research, v.24, p.61-66, 1986.

GOLDBERG, S.; LEBRO, I.; SUAREZ, D.L. Soil colloidal behavior. In: SUMNER, M.E (Ed.) Handbook of soil science. Boca Raton: CRC Press, 2000. cap.6, p.B-195-240.

GRANT, W.H. Abrasion pH, an index of chemical weathearing. Clays and Clay Minerals, v.17, n.3, p.151-155, 1969.

GRIM, R.E. Propriedades das argilas. Cerâmica, v.35, p.18-43, 1963.

HANSON, C.T.; BLEVINS, R.L. Soil water in coarse fragments. Soil Science Society of America Journal, v.43, p-819-820, 1979. 
HERBILLON, A.J.; MAKUMBI, M.N. Weathearing of chlorite in a soil derived from chlorito-schist under humid tropical conditions. Geoderma, v.13, p.89104, 1975.

HILLIER, S. Erosion, sedimentation ans sedimentary origin of clays. In: VELDE, B. (Ed.). Origin and mineralogy of clays: clays and de environment. Berlin : Springer, 1995. cap.4, p.162-214.

HUANG, P.M. Feldspars, olivines, pyroxenes, and amphiboles. In: DIXON, J.B.; WEED, S.B (Ed.) Mineral in soil environments. 2.ed. Madison : SSSA, 1989. cap.20, p163-194.

INGELMO, F.; CUADRADO, S.; IBAÑES, A.; HERNÁNDEZ, J. Hydrici properties of some Spanish in relatio to their rock fragment content: implications for runoff and vegetation. Catena, v.23, p.73-85, 1994.

JACKSON, M.L. Soil chemical analysis : advanced course. Madison: University of Wisconsin, 1969.991p.

KÄMPF, N; SHEINOST, A.C.; SHULZE, D.G. Oxide Minerals. In: SUMNER, M.E (Ed.). Handbook of soil science. Boca Raton: CRC Press, 2000. cap.3, p.F-125-168.

LAVKULICH, L.M. ; WIENS, J.H. Comparison of organic matter destruction by hydrogen peroxide and sodium hypochlorite and its effects on selected mineral constituents. Soil Science Society of America Proceedings, v.34, n.5, p. 755-758, 1970. 
LOUGHNAN, F.C. Chemical weathering of the silicates minerals. New York: Elsevier, 1969.154p.

MACIAS, F.; CHESWORTH, W. Weathering in humid regions, with emphasis on igneous rocks and their metamorphic equivalents. In: MARTINI, I.P..; CHESWORTH, W (Ed.) Weathearing, soils \& paleosols : development in Earth surface processes 2. Amsterdam: Elsevier, 1992. cap.12, p.283-306.

MARSHALL, C.E. Cation exchange determinations for soils. In: JACKSON, M.L. Soil chemical analysis. New Delhi: Prentice-Hall of India Private, 1967. cap. 4 , p.57-81.

MARTIN, R.T. Calcium oxalate formation in soil from hydrogen peroxide treatment. Soil Science, v.77, p.143-145, 1954.

MARTÍN-GARCIA, J.M.; DELGADO, G.; PÁRRAGA, J.F.; GÁMIZ, E. DELGADO, R. Chemical, mineralogical and (micro)morphological study of coarse fragments in Mediterranean red soils. Geoderma, v.90, p-23-47, 1999.

McBRIDE, M.B. Chemisorption of cathechol on gibbsite, boehmeite, and noncrystalline alumina surfaces. Environmental Science Technology, v.22, p.703-708, 1988.

MEHRA, O.P.; JACKSON, M.L. Iron oxide removal from soils and clays by a dithionite-citrate system buffered with sodium bicarbonate. Clays and Clay Minerals, v.7, p.317-327, 1960. 
MILLER, F.T.; GUTHRIE, R.L. Classification and distribution of soils containing rock fragments in the United States. Soil Science Society of America Journal. Erosion and Productivity of Soils Containing Rock Fragments. v.13, n.1/6, 1984.

MITCHELL, B.D.; FARMER, V.C; McHARDY, W.J. Amorphous inorganic materials in soils. Advances in Agronomy, v.16, p.327-383, 1964.

MOORE, D.M.; REYNOLDS JR. R.C. X-ray diffraction and the identification and analysis of clay minerals. New York: Oxford University Press, 1989. $332 \mathrm{p}$.

OADES, J.M. Soil organic matter and structural stability: mechanisms and implications for management. Plant and Soil, v.76, p.319-337, 1984.

OLIER, C. Weathering. Edinburgo: Oliver \& Boyd, 1969, 304p.

OLIVEIRA, J.B. de; JACOMINE, P.K.T.; CAMARGO, M.N. Classes gerais de solos do Brasil : guia auxiliar para seu reconhecimento. 2.ed. Jaboticabal: FUNEP, 1992. 201p.

OLIVEIRA, J.B. de; PRADO, H. do. Carta pedológica semi-detalhada do Estado de São Paulo: Guaíra; projeto cartográfico IGC. Campinas: IAC, 1991. (Escala 1:100.000).

OLSON, C.G.; THOMPSON, M.L.; WILSON, M.A. Phyllosilicates. In: SUMNER, M.E (Ed.) Handbook of soil science. Boca Raton: CRC Press, 2000. cap.2, p.F-77-123. 
PARDO, M.T.; GUADALIX, M.E. Phosphate sorption in allophanic soils and release of sulphate, silicate and hidroxil. Journal of Soil Science, v.41, p.607-612, 1990.

PARFITT, R.L. Anion adsorption by soils and soil minerals. Advances in Agronomy, v. 30, p.1-50, 1978.

POESEN, J.; LAVEE, H. Rock fragments in top soils: significance and processes. Catena, v.23, p.1-28, 1994.

PORTA, J.; LÓPEZ-ACEVEDO, M.; ROQUERO,C. Edafología: para la agricultura y el medio ambiente. Madrid: Ediciones Mundi-Prensa, 1994. $807 \mathrm{p}$.

RAI, D.; KITTRICK, J.A. Mineral equilibria and the soil system. In: DIXON, J.B.; WEED, S.B (Ed.) Mineral in soil environments. 2.ed. Madison : SSSA, 1989. cap.4, p163-194.

RAIJ, B. van. Capacidade de troca de cátions em solos. Estudo comparativo de alguns métodos. Bragantia, v.25, p.327-336, 1966.

RAIJ, B. van. A capacidade de troca de cátions das frações orgânica e mineral em solos. Campinas, 1967. 67p. Tese (Doutorado) - Escola Superior de Agricultura "Luiz de Queiroz", Universidade de São Paulo.

RAIJ, B. van. A capacidade de troca de cátions das frações orgânica e mineral em solos. Bragantia, v.28, n.8, p.85-112, Mar. 1969. 
RAIJ, B van; PEECH, M. Eletrochemical properties of some oxisols and alfisols of the tropics. Soil Science Society of America Proceedings, v.36, p.587$593,1972$.

RAIJ, B. van Fertilidade do solo e adubação. Campinas: Editora Agronômica Ceres/Potafos, 1991.343p.

RAIJ, B. van; CANTARELLA, H.; QUAGGIO, J.A.; FURLANI, A.M.C. Recomendações de adubação e calagem para o Estado de São Paulo. Campinas, IAC, 1996.285p. (IAC. Boletim Técnico, 100)

RANST, E van; SHAMSHUDDIN, J.; BAERT, G; DZWOWA, P.K. Charge characteristics in relation to free iron and organic matter of soils from Bambouto Mountains, Western Cameroon. European Journal of Soil Science, v.49, p.243-252, Jun. 1998.

RASMUSSEN, P.E.; SHERRY, L.S.; NESBIT, H.W. The determination of exchangeable cations in acid soils: Errors caused by weathering reactions during neutral salt extraction. Canadian Journal of Soil Science, v.71, p.155-163, May. 1991.

RESENDE, M.; SANTANA, D.P. Uso da relações ki e kr na estimativa da mineralogia para a classificação dos latossolos. In: REUNIÃO DE CLASSIFICAÇÃO, CORRELAÇÃO DE SOLOS E INTERPRETAÇÃO DE APTIDÃO AGRÍCOLA, 3, Rio de Janeiro, 1988. Anais. Rio de Janeiro: EMBRAPA, SNLCS, 1988. p.225-232. (EMBRAPA. SNLCS. Documentos, 12). 
RHOADES, J.D. Cation exchange capacity. In: PAGE, A.L.; MILLER, R.H.; KEENEY, D.R. (Ed.) Methods of soil analysis: chemical and microbiological properties. Madison: University of Wisconsin, 1982. cap.8, p.154-157.

RIVARD, R.; De KIMPE, C.R. Propriétés de quelques sols riches en graviers dans la région de Québec. Canadian Journal of Soil Science, v.60, p.263$273,1980$.

SAWHNEY, B.L. In: DIXON, J.B.; WEED, S.B (Ed.) Mineral in soil environments. 2.ed. Madison : SSSA, 1989. cap.16, p.789-824.

SCHOBBENHAUS, C; CAMPOS, D.A.; DERZE, G.R.; ASMUS, H.E. Geologia do Brasil. Brasília: Ministério das Minas e Energia; DNPM, 1984. $501 \mathrm{p}$.

SCHWERTMANN, U.; TAYLOR, R.M. Iron Oxides. In: DIXON, J.B.; WEED, S.B (Ed.) Mineral in soil environments. 2.ed. Madison : SSSA, 1989. cap.8, p.380-427.

SPOSITO, G. The chemistry of soils. New York: Oxford University Press, 1989. $277 \mathrm{p}$.

SPOSITO, G. Ion exchange phenomena. In: SUMNER, M.E (Ed.). Handbook of soil science. Boca Raton: CRC Press, 2000. cap.7, p.B-241-263. 
STEVENSON, F.J. Humus chemistry: genesis, composition and reactions. New York: John Wiley, 1994. 496p.

SUGUIO, K. Dicionário de geologia sedimentar e áreas afins. Rio de Janeiro: Bertrand Brasil, 1998. 120p.

TABOADA, T.; ROMERO, R.; GARCIAA-PAZ, C. Weathearing evolution of a biotite granite. Chemical-Geology, v.84, n.1/4, p.130-132, 1990.

TAN, K.H. Principles of soil chemistry. 2.ed. New York: Dekker, 1993. 362p.

TEDROW, J.C.F. Properties of sand and silt fractions in New Jersey soils. Soil Science, v.101, n.1, p.24-30, 1965.

TESSENS, E.; SHAMSHUDDIN, J. Characteristics related to charges in Oxisols of Peninsular Malaysia. Pedologie, v.32, p.85-106, 1982.

THOMPSON, M.L.; ZHANG, H.; KAZEMI, M.; SANDOR, J.A. Contribution of organic matter to cation exchange capacity and surface area of fractionated soil materials. Soil Science, v.148, p.250-257, 1989.

TURPAULT, M.P.; BONNAUD, P.; FICHTER, J.; RANGER, J.; DAMBRINE, E. Distribution of cation exchange capacity between organis matter and mineral fractions in acid forest soils (Vosges mountains, France). European Journal of Soil Science, v.47, p.545-556, Dec. 1996. 
UEHARA, G.; GILLMAN, G. Charge characteristics of soils with variable and permanent charge minerals: I. Theory. Soil Science Society of America Journal, v.44, p.250-252, 1980.

UGOLINI, F.C.; CORTI, C.; AGNELLI, A.; PICCARDI, F. Mineralogical, physical and chemical properties of rock fragments in the soil. Soil Science, v.161, p.521-542, Aug. 1996.

VERDADE, F.C. Influência da matéria orgânica na capacidade de troca de cátions do solo. Bragantia, v.15, p.35-42, 1956.

WEAVER, D.M.; RITCHIE, G.S.P.; GILKES, R.J. Phosphorus sorption by gravels in lateritic soils. Australian Journal of Soil Research, v.30, p.319330, 1992.

YU, T.R. Chemistry of variable charge soils. New York: Oxford University Press, 1997. 505p.

ZHANG, X.N.; ZHAO , A.Z. Surface charge. In: YU, T.R. Chemistry of variable charge soils. New York: Oxford University Press, 1997. cap.2, p.1760. 
APÊNDICE 
Apêndice 1. Coeficientes de correlação entre $\mathrm{CTC}_{\mathrm{e}}$ do solo determinada em $\mathrm{BaCl}_{2}$ e diversos atributos dos solos.

\section{Atributo}

Coeficiente de correlação $(r)$

CTC silte

$0.78^{* *}$

CTC argila

$0.05(\mathrm{~ns})$

CTC areiatotal

$0.68^{* *}$

CTC AG+AMG

$0.69^{* * *}$

CTC AM

$0.52^{* *}$

CTC AF

0.41 *

CTC AMF

$0.90 * * *$

pH de abrasão

$0.43^{*}$

Fe livre

-0.06 (ns)

Fe mal cristalizado

$0.47^{*}$

Soma de bases

$0.95^{* * *}$

$\mathrm{Al}_{2} \mathrm{O}_{3}$

$-0.11(\mathrm{~ns})$

$\mathrm{m} \%$

$-0.47^{*}$

Al

$-0.18(\mathrm{~ns})$

Matéria orgânica

$0.71 * * *$

$\%$ silte

$0.42^{*}$

\%argila

0.29 (ns)

$\%$ areia total

$-0.44 *$

$\% \mathrm{AG}+\mathrm{AMG}$

$-0.05(\mathrm{~ns})$

$\%$ AM

$-0.38(\mathrm{~ns})$

$\% \mathrm{AF}$

$-0.37(\mathrm{~ns})$

$\% \mathrm{AMF}$

-0.24 (ns)

${ }^{*} \mathrm{P}<0,05 ;{ }^{* *} \mathrm{P}<0,01 \% ;{ }^{* * *} \mathrm{P}<0,001 \%$; (ns) não significativo. 
Apêndice 2. Coeficientes de correlação entre $\mathrm{CTA}_{\mathrm{e}}$ do solo determinada em $\mathrm{BaCl}_{2}$ e diversos atributos dos solos.

\section{Atributo}

Coeficiente de correlação $(r)$

$\begin{array}{lc}\text { CTA silte } & 0.17(\mathrm{~ns}) \\ \text { CTA argila } & 0.27(\mathrm{~ns}) \\ \text { CTA areiatotal } & -0.32(\mathrm{~ns}) \\ \text { CTA AG+AMG } & 0.12(\mathrm{~ns}) \\ \text { CTA AM } & -0.12(\mathrm{~ns}) \\ \text { CTA AF } & -0.35(\mathrm{~ns}) \\ \text { CTA AMF } & -0.34(\mathrm{~ns}) \\ \text { pH de abrasão } & 0.25(\mathrm{~ns}) \\ \text { Fe livre } & 0.36(\mathrm{~ns}) \\ \text { Fe mal cristalizado } & 0.12(\mathrm{~ns}) \\ \text { Soma de bases } & -0.23(\mathrm{~ns}) \\ \mathrm{Al} \mathrm{O}_{3} & 0.62 * * * \\ \text { m\% } & -0.28(\mathrm{~ns}) \\ \mathrm{Al} & -0.22(\mathrm{~ns}) \\ \text { Matéria orgânica } & -0.15(\mathrm{~ns}) \\ \text { \%silte } & 0.02(\mathrm{~ns}) \\ \text { \%argila } & 0.43 * \\ \text { \%areia total } & -0.37(\mathrm{~ns}) \\ \text { \%AG+AMG } & 0.05(\mathrm{~ns}) \\ \text { \%AM } & -0.21(\mathrm{~ns}) \\ \text { \%AF } & -0.40(\mathrm{~ns}) \\ \text { \%AMF } & -0.30(\mathrm{~ns})\end{array}$

${ }^{*} \mathrm{P}<0,05 ;{ }^{* *} \mathrm{P}<0,01 \%$; ${ }^{* *} \mathrm{P}<0,001 \%$; (ns) não significativo. 
Apêndice 3: Resumo informativo da análise de regressão para CTC e CTA.

1. CTC

Summary of stepwise selection

\begin{tabular}{lccccc}
\hline $\begin{array}{c}\text { Variable step } \\
\text { entered }\end{array}$ & $\begin{array}{c}\text { Number } \\
\text { vars }\end{array}$ & $\begin{array}{c}\text { Partial R- } \\
\text { square }\end{array}$ & $\begin{array}{c}\text { Model R- } \\
\text { square }\end{array}$ & F value & Pr $>$ F \\
\hline 1 CTC amf & 1 & 0,8163 & 0,8163 & 102,19 & $<0,0001$ \\
$2 \mathrm{MO}$ & 2 & 0,0361 & 0,8524 & 5,38 & 0,0300 \\
\hline
\end{tabular}

2. CTA

Summary of stepwise selection

\begin{tabular}{lccccc}
\hline $\begin{array}{l}\text { Variable step } \\
\text { entered }\end{array}$ & $\begin{array}{c}\text { Number } \\
\text { vars }\end{array}$ & $\begin{array}{c}\text { Partial R- } \\
\text { square }\end{array}$ & $\begin{array}{c}\text { Model R- } \\
\text { square }\end{array}$ & F value & Pr $>$ F \\
\hline $\mathbf{A l}_{\mathbf{2}} \mathbf{O}_{3}$ & 1 & 0,3852 & 0,3852 & 14,41 & 0,0009 \\
$\mathbf{M O}$ & 2 & 0,0773 & 0,4626 & 3,16 & 0,0891 \\
$\mathbf{m} \%$ & 3 & 0,0535 & 0,5161 & 2,32 & 0,1424 \\
areia grossa \% & 4 & 0,0514 & 0,5675 & 2,38 & 0,1389 \\
\hline
\end{tabular}

